UNIVERSIDADE DE SÃO PAULO

ESCOLA DE ENFERMAGEM

CANDICE HEIMANN

GESTÃo DE PROJETO EDUCACIONAL A DISTÂNCIA NA PERSPECTIVA DO GUIA PMBOK

SÃO PAULO

2017 
CANDICE HEIMANN

\title{
GESTÃo DE PROJETO EDUCACIONAL A DISTÂNCIA NA PERSPECTIVA DO GUIA PMBOK
}

\author{
Versão corrigida da Tese apresentada ao \\ Programa de Pós-Graduação em \\ Gerenciamento em Enfermagem da Escola \\ de Enfermagem da Universidade de São \\ Paulo para obtenção do título de Doutora em \\ Ciências da Saúde
}

Área de Concentração: Fundamentos e Práticas de Gerenciamento em Enfermagem e em Saúde

Orientadora: Prof ${ }^{-a} r^{a}$ Cláudia Prado

\section{VERSÃO CORRIGIDA}

A versão original encontra-se disponível na Biblioteca da Escola de Enfermagem da Universidade de São Paulo e na Biblioteca Digital de Teses e Dissertações da Universidade de São Paulo.

\section{SÃO PAULO}


AUTORIZO A REPRODUÇÃO E DIVULGAÇÃO TOTAL OU PARCIAL DESTE TRABALHO, POR QUALQUER MEIO CONVENCIONAL OU ELETRÔNICO, PARA FINS DE ESTUDO E PESQUISA, DESDE QUE CITADA A FONTE.

Assinatura:

Data:

\section{Catalogação na Publicação (CIP) \\ Biblioteca "Wanda de Aguiar Horta" \\ Escola de Enfermagem da Universidade de São Paulo}

Heimann, Candice

Gestão de projeto educacional a distância na perspectiva do guia PMBOK / Candice Heimann. São Paulo, 2017.

$158 \mathrm{p}$.

Tese (Doutorado) - Escola de Enfermagem da Universidade de São Paulo.

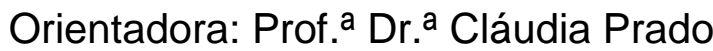

Área de concentração: Fundamentos e práticas de gerenciamento em enfermagem e em saúde.

1. Gestão do conhecimento. 2. Educação a distância. 3. Projeto de pesquisa. 4. Guias. 5. Enfermagem I. Título. 


\section{FOLHA DE APROVAÇÃO}

Nome: Candice Heimann

Título: Gestão de projeto educacional a distância: uma proposta baseada no Guia PMBOK.

Tese apresentada a Escola de Enfermagem da Universidade de São Paulo para obtenção do título de Doutora em Ciências da Saúde

Aprovado em:

Banca Examinadora

Prof. Dr.: Instituição:

Julgamento: Assinatura:

Prof. Dr.: Instituição:

Julgamento: Assinatura:

Prof. Dr.: Instituição:

Julgamento: Assinatura:

Prof. Dr.: Instituição:

Julgamento: Assinatura:

Prof. Dr.: Instituição: Julgamento: Assinatura: 


\section{Dedicatória}

Ao meu filho, Pedro Michel Heimann Moraes Por nunca ter me permitido visualizar os conhecimentos de forma compartimentada;

Por nunca ter me permitido enxergar algumas habilidades como mais importantes

que outras;

Por nunca ter me permitido achar que há momentos específicos para aprender cada coisa;

Por nunca ter me permitido contentar-me com pouco; Por nunca ter me permitido achar que o hoje, já é suficiente; Por nunca ter me permitido medir minhas capacidades;

Por nunca ter me permitido apenas consumir ideias.

Te amo. 


\section{Agradecimento Especial}

A Professora Cláudia Prado

Eu não estou aqui sozinha e se hoje recebo um título, não recebo sozinha. Há momentos em que a vida nos obriga a olhar em volta e fazer uma análise dos nossos ganhos e de nossas perdas, e se hoje eu estou ganhando algo, é porque sou resultado de sua influência.

Você esteve comigo a cada segundo, sempre a poucos metros de mim. Centenas de personagens me formaram e me educaram, mas você foi diferente:

fez-me subir degraus.

E a ti, serei eternamente grata! 


\section{Agradecimentos}

A Deus e a todos os espíritos de luz que acompanharam minha trajetória, rica em experiências e oportunidades de crescimento.

A meus pais Celia e Bertholdo Heimann, pelo apoio incondicional em todas as escolhas de minha vida.

A meus pais paulistas Elisabeth Dupont e José Maria Rimoli, por estarem sempre presentes nesta minha caminhada, me apoiando e dando forças para continuar, presencialmente ou a distância.

Aos discentes de enfermagem, meus eternos pontos de partida, de reflexão e ação sobre o ensino e a aprendizagem.

A Profa. Dra. Heloisa Helena Ciqueto Peres, por acreditar em mim a primeira vista no mestrado e a segunda vista, no doutorado. Foi você que abriu as portas deste mundo para mim!

A Profa. Maria Madalena Januário, meu reconhecimento pelo carinho e pelas valiosas contribuições no exame de qualificação e por ter sido minha inspiração de vir para USP.

A todos os professores do ENO, pelos conhecimentos a mim fornecidos. Obrigada!

As Enfermeiras Denise Maria de Almeida, Débora Vaz e Lúcia Tobase pela disponibilidade, paciência e apoio técnico no desenvolvimento deste trabalho.

A Harriet Maruxo, Naarah Dantas, Danielle Souza, mais que colegas... amigas, por favorecerem e apoiarem o meu dia a dia, em São Paulo e em Recife, facilitando com alegria o meu crescimento profissional.

À Equipe da Secretaria do Departamento de Orientação Profissional, pela presteza e solicitude no atendimento, disponibilidade, carinho e os sorrisos abertos, sempre em meus retornos interestaduais.

À Equipe da Secretaria do Programa de Pós-graduação em Enfermagem, em especial, à Silvana Maximiano e Márcia Garcia, pelo auxílio e orientação ao longo dessa jornada. 
A todos aqueles que, de uma forma ou de outra, contribuíram para a realização deste trabalho. 
Heimann, C. Gestão de projeto educacional a distância na perspectiva do Guia PMBOK. [tese] São Paulo, SP Brasil: Escola de Enfermagem, Universidade de São Paulo, 2017.

\section{RESUMO}

Introdução: Durante o processo de implantação de cursos na modalidade a distância, a etapa de planejamento e gerenciamento do curso é um dos temas que vem ocupando as discussões dos envolvidos na projeção e execução das propostas educacionais, muitas vezes com finalidades que excedem o nível do educacional e esbarram também em questões de cunho administrativo e econômico. O fato de que, na Educação a Distância (EAD), se está lidando com sujeitos e instituições de características diversas assim como tecnologias das mais sofisticadas, não tem assegurado igual avanço nos modelos pedagógicos do ensino, e menos ainda, na qualidade da gestão desses projetos. Objetivo: Desenvolver um projeto educacional a distância através das ferramentas de gestão existentes no Guia Project Management Body of Knowledge (PMBOK). Método: O estudo constituiu-se de uma pesquisa aplicada, de produção tecnológica com análise exploratório-descritiva. Quanto a técnica, foi empregado o estudo de caso de análise documental. Resultados: Neste projeto foram consideradas a existência de 5 fases do ciclo de vida que fundamentam o modelo do processo de gerenciamento de projetos, abrangendo todo percurso desde a concepção ao encerramento, identificadas por Inicialização, Planejamento, Execução, Monitoramento e Controle, Encerramento. Para inclusão das diretrizes em consonância com as orientações do Guia PMBOK, as 10 áreas de conhecimento foram selecionadas pela equipe do projeto, uma vez que elas englobam todas as ações gerenciais de um curso a distância, todavia, de acordo com o perfil do projeto, utilizou-se somente parte destes processos. A integração exerceu papel essencial no gerenciamento do curso, à medida que, criou condições propícias para 0 desenvolvimento do projeto através do estabelecimento do objetivo de capacitar profissionais no uso de Tecnologias Digitais de Informação e Comunicação como recursos pedagógicos através da EAD baseando-se na aprendizagem significativa, no uso da metodologia dialética e das metodologias ativas, vinculadas a mediação da aprendizagem na era digital. Conclusões: Cada área de conhecimento do Guia PMBOK teve em seus processos a organização de acordo com as demandas e conhecimentos do projeto e dos gestores, com ênfase no planejamento educacional. $O$ detalhamento conceitual e operacional foi analisado de forma a orientar os aspectos essenciais para o planejamento de um projeto em EAD dentro de um contexto gerencial norteada pelo modelo das boas práticas em gestão de projetos. O planejamento por unidades de aprendizagem, o monitoramento, o controle e os critérios de qualidade estabelecidos foram fundamentais para as tomadas de decisão no gerenciamento. $O$ estabelecimento das atividades predominantes do projeto educacional e sua finalidade principal fizeram que os produtos fossem desenvolvidos dentro do que era almejado pelos stakeholders, sendo benquistos sem qualquer restrição. 
Palavras chave: Gestão do Conhecimento; Guia de Boas Práticas; Projeto; Educação a distância. 
Heimann, C. Management of educational project in the distance from the perspective of PMBOK Guide. [Thesis] São Paulo, SP Brazil: School of Nursing, University of São Paulo, 2017.

\begin{abstract}
Introduction: During the process of implementation of Education Distance Learning (EDL), the planning stage and management of the course is one of the themes that has been occupying the discussions of those involved in designing and implementing educational proposals, often for purposes that exceed the educational level and also run into administrative and economic nature issues. The fact that, in distance education, you're dealing with subjects and different characteristics of institutions as well as the most sophisticated technologies, has not ensured equal advance in pedagogical teaching models, and even less in quality management. Objective: To develop an educational project in the distance through the existing management tools in the Project Management Body of Knowledge Guide (PMBOK). Method: The study consisted of an applied research, production technology with exploratory and descriptive analysis. As for technique, we used the case study of document analysis. Results: In this project we considered the existence of 5 phases of the life cycle that base the model of the process of project management, covering all path from conception to closure, identified by Initialization, Planning, Execution, Monitoring and Control, Finalization. In accordance with the guidelines of the PMBOK Guide, the 10 areas of knowledge were selected by the project team, since they encompass all managerial actions of a distance course, however, according to the project profile, only part of these processes were used. Integration has played an essential role in the management of the course, as it has created favorable conditions for the development of the project through the establishment of the objective of training professionals in the use of Digital Information and Communication Technologies as pedagogical resources through distance education based in meaningful learning, in the use of dialectical methodology and active methodologies, linked to the mediation of learning in the digital epoch. Conclusions: Each PMBOK Guide Knowledge area had in its processes the organization according to the demands and knowledge of the design and management, with an emphasis on educational planning. The conceptual and operational details was analyzed in order to guide the essentials for planning a project in distance education in a managerial context guided by the model of good practice in project management. Planning for learning units, monitoring, control and quality criteria were essential for decision-making in management. The establishment of the predominant activities of the educational project and its main purpose made that the products were developed within what was desired by the stakeholders, being well liked without any restriction.
\end{abstract}

Keywords: Knowledge Management; Good Practice Guide; Project; Education Distance Learning 


\section{LISTA DE FIGURAS}

Figura 1 - Projetos como o caminho para atingir a visão organizacional...............38

Figura 2 - Estrutura do ciclo de vida de um projeto. …………………............... 39

Figura 3 - Ciclo de vida para realização de um projeto de curso educacional...... 40

Figura 4 - Projeto de fase única com um grupo de processos............................. 41

Figura 5 - Projeto de várias fases com vários grupos de processos..................... 42

Figura 6 - Grupos de processos de gerenciamento de projetos.......................... 44

Figura 7 - Ciclo de vida de um projeto por grupo de processos. ......................... 45

Figura 8 - Fluxo de processos e áreas de conhecimento. .................................. 48

Figura 9 - Ciclo de vida do projeto subdividido em fases...................................87

Figura 10 - Mapa mental do grupo de processos de gestão de processos do

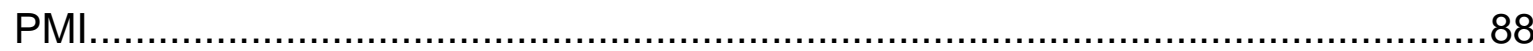

Figura 11 - Mapa Mental das áreas de conhecimento do Guia PMBOK................93

Figura 12 - Mapa Mental dos processos e ações envolvidas no Gerenciamento da Integração. .94

Figura 13 - Mapa Mental dos processos e ações envolvidas no Gerenciamento do Escopo. .104

Figura 14 - Mapa Mental dos processos e ações envolvidas na Estrutura Analítica do Projeto 105

Figura 15 - Mapa Mental dos Processos de Gerenciamento do Tempo distribuídos ao longo das fases do projeto. 108

Figura 16 - Mapa Mental dos processos e ações envolvidas no Gerenciamento de Custos. 111

Figura 17 - Mapa Mental dos processos e ações envolvidas no Gerenciamento da Qualidade 112

Figura 18 - Mapa Mental dos processos e ações envolvidas no Gerenciamento dos Recursos Humanos. 114

Figura 19 - Mapa Mental dos processos e ações envolvidas no Gerenciamento das Comunicações

Figura 20 - Mapa Mental dos processos e ações envolvidas no Gerenciamento de Riscos. 
Figura 21 - Mapa Mental dos processos e ações envolvidas no Gerenciamento

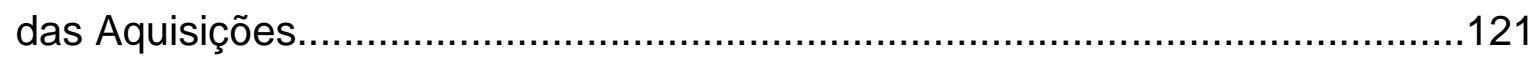

Figura 22 - Mapa Mental dos processos e ações envolvidas no Gerenciamento das Partes Interessadas............................................................................123 


\section{LISTA DE QUADROS}

Quadro 1 - Indicadores de qualidade para Educação a Distância .........................34

Quadro 2 - Diferenças entre Projetos e Processos ………………………........36

Quadro 3 - Áreas de conhecimento do PMBOK .................................................46

Quadro 4 - Grupo de processos de gerenciamento de projetos e mapeamento das áreas de conhecimento 49

Quadro 5 - Módulos do Curso de capacitação de profissionais no uso de tecnologias digitais de informação e comunicação como recursos pedagógicos...81

Quadro 6 - Plano de gerenciamento do projeto do curso. .96

Quadro 7 - Modelo de Monitoramento por cursista de acordo com as atividades de aprendizagem do curso 102

Quadro 8 - Modelo de Memória de Atividades do Curso. 102

Quadro 9 - Plano de gerenciamento do cronograma do curso. 108

Quadro 10 - Matriz do Quadro lógico com Checklist do Plano de Monitoramento e Avaliação com ênfase em diagnóstico e documentação 138

Quadro 11 - Matriz do Quadro lógico dos referenciais metodológicos-conceituais por componentes do sistema educacional com ênfase em resultados esperados e indicadores de resultados.

Quadro 12 - Checklist do Plano de Controle do Cronograma do curso. 143

Quadro 13 - Tabela das tarefas e participação nas unidades de aprendizagem por cursista. 


\section{LISTA DE SIGLAS}

AAC

ABED

ABProj

ABRAED

AVA

BoKs

CCE-USP

CEP

CETENF

- EEUSP

CNPq

EAD

EAP

EEUSP

ENO

FMUSP

GEPETE

GP

LDBE

MEC

Moodle

MQL

PGP

PMBOK

PMA

PMI
Aprendizagem Assistida por Computador

Associação Brasileira de Ensino a Distância

Aprendizagem Baseada em Projetos

Anuário Brasileiro Estatístico de Educação Aberta a Distância

Ambiente Virtual de Aprendizagem

Body of Knowledge

Centro de Computação Eletrônica da Universidade de São Paulo

Comitê de Ética em Pesquisa

Centro de Teleenfermagem da Escola de Enfermagem da Universidade de São Paulo

Conselho Nacional de Desenvolvimento Científico e Tecnológico

Educação a Distância

Estrutura Analítica do Projeto

Escola de Enfermagem da Universidade de São Paulo

Departamento de Orientação Profissional

Faculdade de Medicina da Universidade de São Paulo

Grupo de Estudos e Pesquisas de Tecnologia da Informação nos Processos de Trabalho em Enfermagem

Gestão de Projetos

Lei de Diretrizes e Bases da Educação

Ministério da Educação e Cultura

Modular Object-Oriented Dynamic Learning Environnent

Método do Quadro Lógico

Plano de Gerenciamento do Projeto

Project Management Body of Knowledge

Plano de Monitoramento e Avaliação

Project Management Institute 
PPGEn

QL

SEED

SMA

TCLE

TDIC

UFPE

UMUC

UTI

VSA

WBS

ZDP
Programa de Pós-Graduação em Gerenciamento em Enfermagem

Quadro Lógico

Secretaria de Educação a Distância

Sistema de Monitoramento e Avaliação

Termo de Consentimento Livre e Esclarecido

Tecnologias Digitais da Informação e Comunicação

Universidade Federal de Pernambuco

University of Maryland University College

Unidade de Terapia Intensiva

Virtualização da Sala de Aula

Work Breackdown Structure

Zona de Desenvolvimento Proximal 


\section{SUMÁRIO}

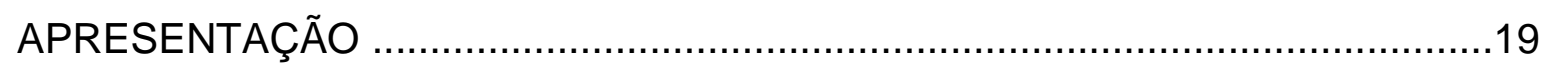

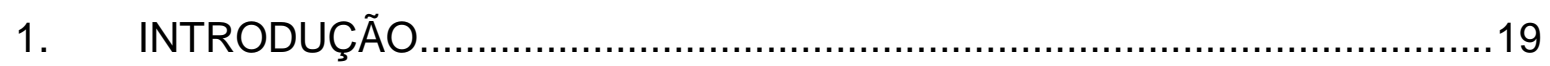

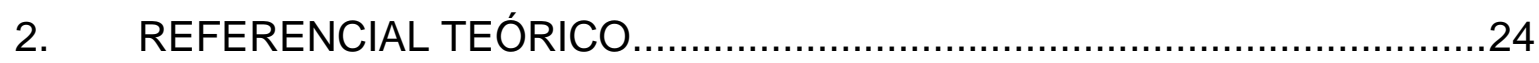

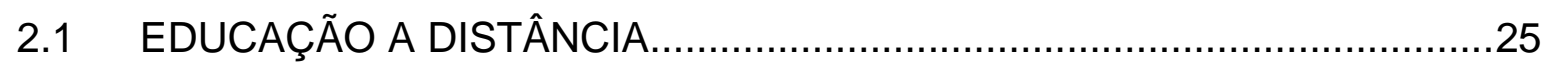

2.1.1 A Educação a Distância na Perspectiva da Sociedade da

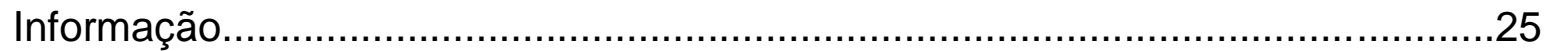

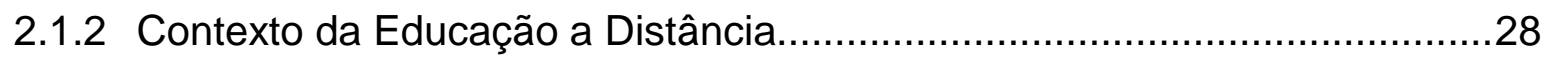

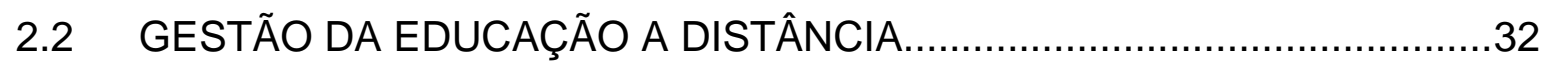

2.2.1 Gestão de Cursos em Educação a Distância............................................32

2.2.2 Referenciais de Qualidade para a Educação a Distância............................33

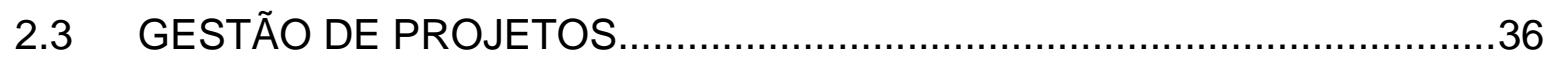

2.3.1 Definições e Características da Gestão de Projetos......................................36

2.3.2 Grupos de processos na Gestão de Projetos.........................................44

2.3.3 Grupos de processos e áreas de conhecimento no Guia PMBOK..............46

2.4 Adoção do Modelo Project Management Institute (PMI) e do Guia PMBOK

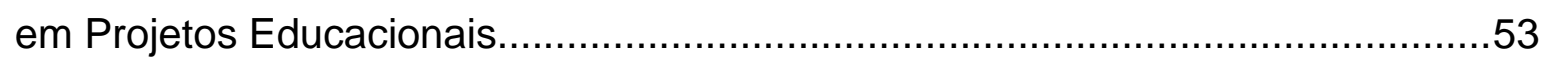

2.4.1 Conceitos do Modelo PMBOK Aplicados aos Projetos de Educação a

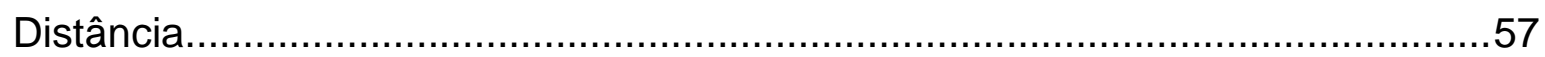

2.4.2 Gestão de Projetos Educacionais a Distância: Capacitação de Profissionais para o uso de TDIC como Recursos Pedagógicos na Educação............................60

3. REFERENCIAL METODOLÓGICO CONCEITUAL..................................66

3.1 CONCEPÇÕES SOBRE AS TEORIAS DE JOHN DEWEY, DONALD

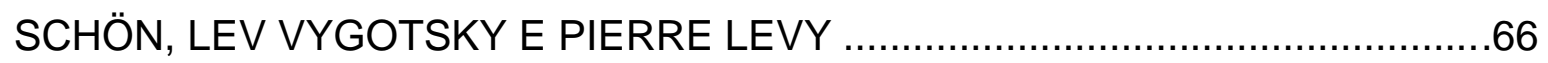

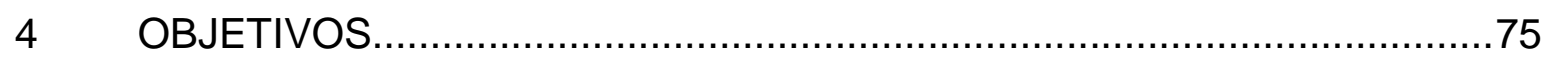

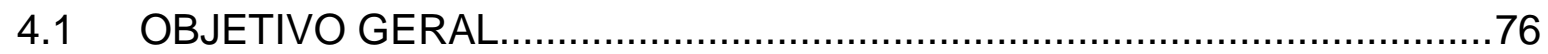

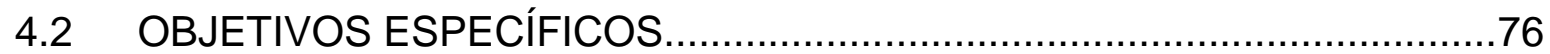

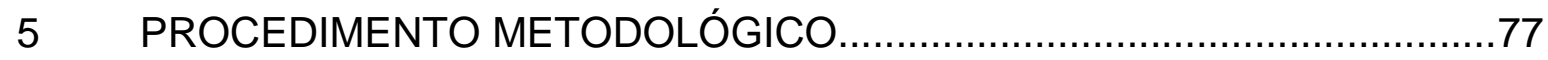

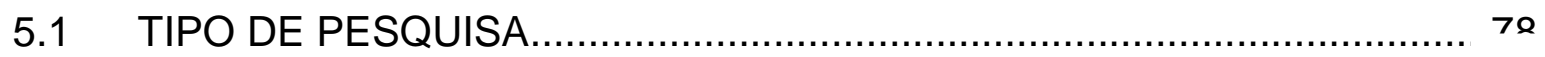

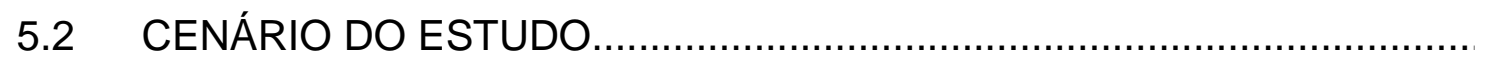

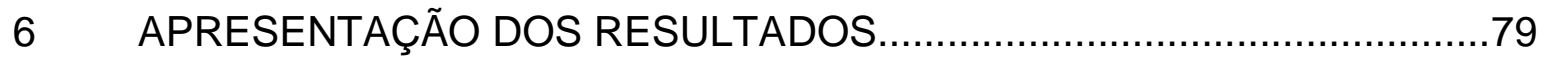

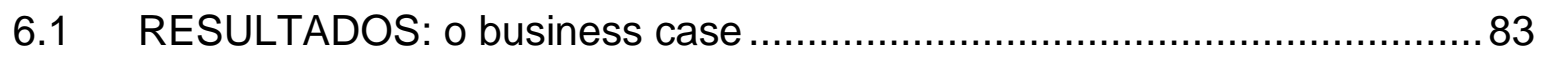




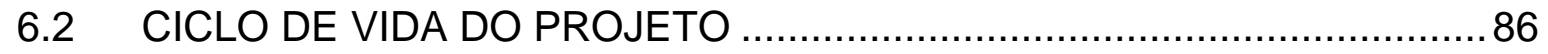

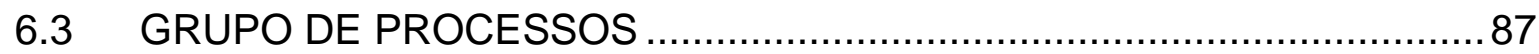

6.4 ÁREAS DE CONHECIMENTO PARA GERENCIAMENTO DO

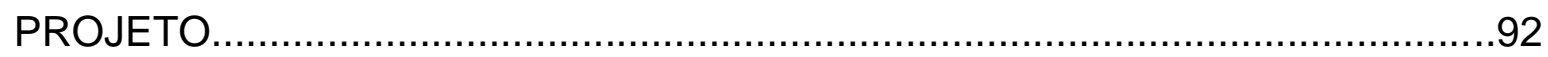

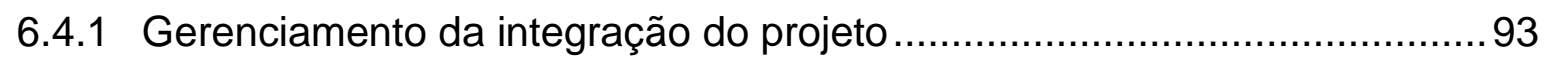

6.4.2 Gerenciamento do escopo do projeto ............................................... 103

6.4.3 Gerenciamento do tempo do projeto..................................................106

6.4.4 Gerenciamento dos custos do projeto …………………………........110

6.4.5 Gerenciamento da qualidade do projeto ….......................................112

6.4.6 Gerenciamento dos recursos humanos do projeto ................................114

6.4.7 Gerenciamento das comunicações do projeto ......................................116

6.4.8 Gerenciamento dos riscos do projeto ...............................................117

6.4.9 Gerenciamento das aquisições do projeto ………............................. 120

6.4.10 Gerenciamento das partes interessadas no projeto................................. 121

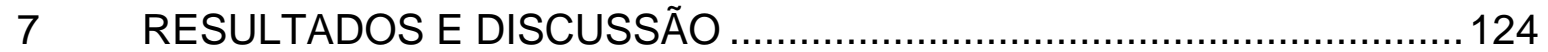

8 EFETIVIDADE DAS AÇÕES CONTIDAS NO PLANO DE

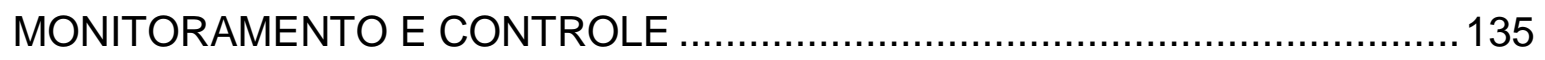

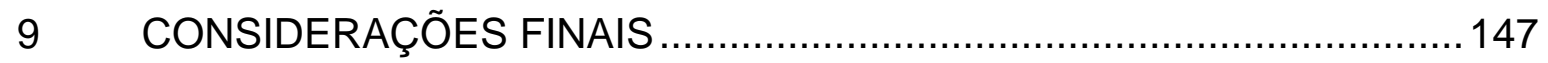

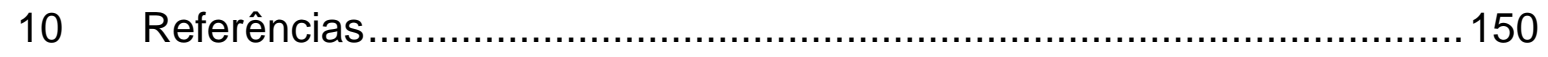

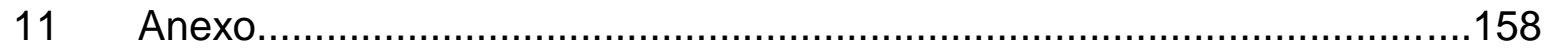




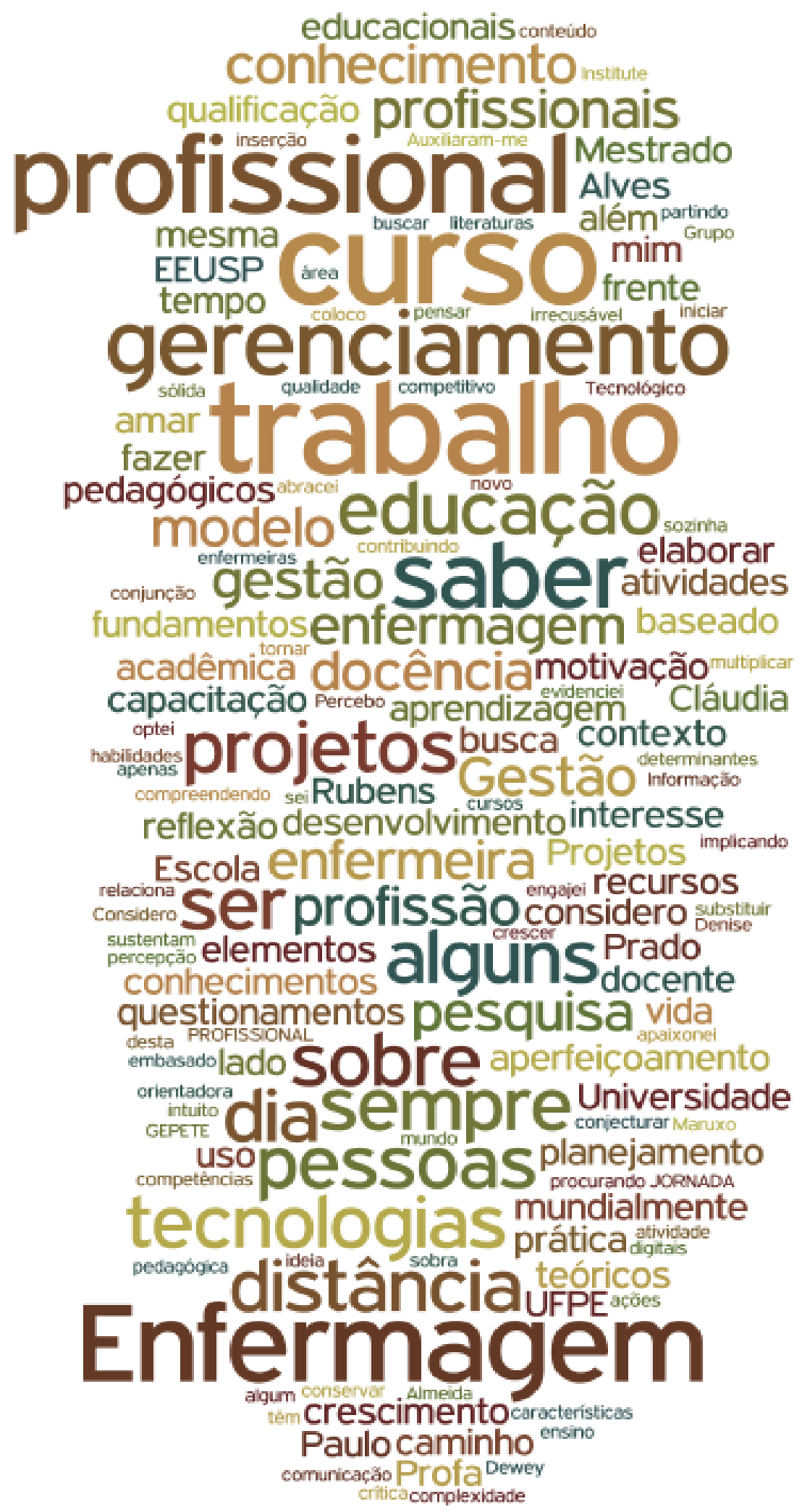

APRESENTAÇÃO 


\section{APRESENTAÇÃO}

"Mas na profissão, além de amar, tem de saber. E o saber leva tempo para crescer". Rubens Alves

Considero importante fazer uma retrospectiva profissional e acadêmica, pois é justamente onde evidenciei meu interesse pela educação permanente, atividade que aprendi a desenvolver quando trabalhei como enfermeira em um hospital privado da cidade de Recife, pela docência, profissão que abracei quando conclui a Licenciatura em Enfermagem na Universidade Federal de Pernambuco (UFPE) e pela pesquisa, uma prática que me apaixonei desde o primeiro dia de mestrado na Escola de Enfermagem da Universidade de São Paulo.

Alguns fatores foram determinantes para esse interesse, entre eles, destaco minha Graduação em Enfermagem, minhas atividades como enfermeira de Unidades de Terapia Intensiva e Emergência, a coordenação de um setor de Educação Coorporativa, o cargo de Professora substituta na UFPE, a Coordenação de um curso de graduação em Enfermagem, o Mestrado e o Doutorado.

Trabalhar nestas atividades para mim sempre tiveram a mesma motivação: formar grupos de trabalho coesos, dotados de habilidades e conhecimentos, baseado em um bom relacionamento interpessoal com profissionais das diversas áreas, que interagissem com as lideranças e que se responsabilizassem pelo seu aperfeiçoamento profissional. Desse modo fui compreendendo a importância do gerenciamento de processos e projetos na estratégia do desenvolvimento das pessoas e seus reflexos na qualidade profissional.

Sempre acreditei no conhecimento científico como diferencial competitivo entre as pessoas, aliado, claro, a ações humanas integradas no contexto. Porque como profere Rubens Alves: "na profissão, além de amar, tem de saber". E partindo desta premissa, os professos de qualificação na enfermagem, na docência e na pesquisa, me envolveram plenamente, e considero que todas as formas de aprendizagem que tenho experimentado muito têm contribuído para meu crescimento. 
Percebo a complexidade dos papéis que envolvem o ser enfermeira, gestora, docente, e pesquisadora. Por isso, quando me considero atualizada em algum conteúdo, sei que será apenas por alguns momentos, e que em seguida, terei que iniciar um novo procedimento de transformação, e este caminho, não posso trilhar sozinha. $O$ trajeto mais abrangente e alinhado com a minha realidade é a do modelo de gestão que enfatize a potencialização da aprendizagem das pessoas, contribuindo para o desenvolvimento de conhecimentos voltados aos resultados.

A educação como o trabalho são elementos que me acompanham ao longo da existência, e a relação da educação com o mundo do trabalho tem exigido cada vez mais técnicas, tecnologias e inovações, implicando conservar as informações do saber adquirido e ao mesmo tempo criticar e substituir o saber existente.

Compreendo que a qualificação dos profissionais, na saúde ou na docência, não deverá ser reduzida ao exercício das funções sociais, a aprendizagem instrumental de normas ou o domínio de equipamentos e serviços para sua adaptação às oportunidades existentes ligadas somente a empregabilidade. Os profissionais destas áreas devem se pautar pela intensificação das oportunidades de ensino-aprendizagem, da autonomia na busca de conhecimentos mais amplos e da liberdade de criar oportunidades de serem protagonistas de sua própria história.

E nesta conjunção, realizei o Mestrado Acadêmico na Escola de Enfermagem da Universidade de São Paulo (EEUSP) finalizando no ano de 2010, com a missão pessoal e profissional de aprofundar novos saberes, multiplicar experiências e elaborar um curso de capacitação a distância para os docentes de enfermagem, ao lado de minha orientadora Profa. Dra. Cláudia Prado, que sempre me acompanhou de forma crítica e afetuosa.

Rigor e afeto. Dois elementos cuja presença no dia a dia é fundamental para tornar a vida acadêmica mais consistente e efetiva. Por isso minha gratidão a esta educadora será eterna. Ao lado de Profa. Cláudia Prado, partilhei a vida e o trabalho, me sentindo sempre estimulada a seguir em frente na busca da educação de que necessitei e desejei. 
A partir de então, tive a percepção do caminho que teria que percorrer, no sentido de me dedicar profundamente ao doutorado e a pesquisa, adquirir novas literaturas voltadas para a Gestão de Projetos, a qualificação docente e a inserção das tecnologias como recursos pedagógicos no intuito de buscar uma base sólida de conhecimento que pudesse me auxiliar na gestão de um curso a distância.

Como oportunidade de crescimento profissional e de busca do conhecimento sobre o uso das tecnologias no ensino e na área de enfermagem, me engajei no Grupo de Estudos e Pesquisas de Tecnologia da Informação nos Processos de Trabalho em Enfermagem (GEPETE) da EEUSP vinculado ao Conselho Nacional de Desenvolvimento Científico e Tecnológico (CNPq), tendo como algumas de suas integrantes, as enfermeiras Denise Maria de Almeida, Débora Rodrigues Vaz, Harriet Maruxo e Lúcia Tobase.

Aliada a estas profissionais generosas, suscitou a cobiça de elaborar um curso de capacitação de profissionais no uso de tecnologias digitais de informação e comunicação como recursos pedagógicos em paralelo a emersão de alguns questionamentos tal como: "Como planejar e gerenciar projetos educacionais com estas características?", "Como conjecturar um curso baseado em um modelo de gerenciamento reconhecido mundialmente?", "Construir competências para o gerenciamento de projetos: por que e para quê?",

Ao reflexionar sobre estes questionamentos, obtive o panorama acerca do contexto que se relaciona com o tema deste estudo e para isso optei em apresentar alguns fundamentos teóricos que sustentam o gerenciamento de projetos educacionais e o planejamento de um curso a distância associada ao modelo do Project Management Institute (PMI) e do Guia Project Management Body of Knowledge (PMBOK), e embasado nos referenciais teóricos de Lev Vygotsky, Pierre Lévy, John Dewey e Donald Schön.

Auxiliaram-me neste movimento a prática e a reflexão sobra a gestão, o fazer e pensar sobre a docência e a motivação do trabalho em equipe, num exercício contínuo de razão e paixão por uma ideia irrecusável de que, aliada a pessoas melhores, eu melhoraria a mim mesma e o futuro de meus aprendizes, que eu coloco sempre a frente, como ideais a serem buscados.

Por isso, este trabalho não pretende ser qualificado como um trabalho de Gestão de Projetos ou de Gerenciamento de cursos a distância. A intenção que 
me move é a de realizar uma articulação entre Gestão e Docência, trazendo ao campo do gerenciamento uma reflexão pedagógica sobre o planejamento de um curso de aperfeiçoamento profissional e procurando explorar alguns conceitos mundialmente reconhecidos articulados a fundamentos teórico-epistemológicos e a vivência de situações concretas. 


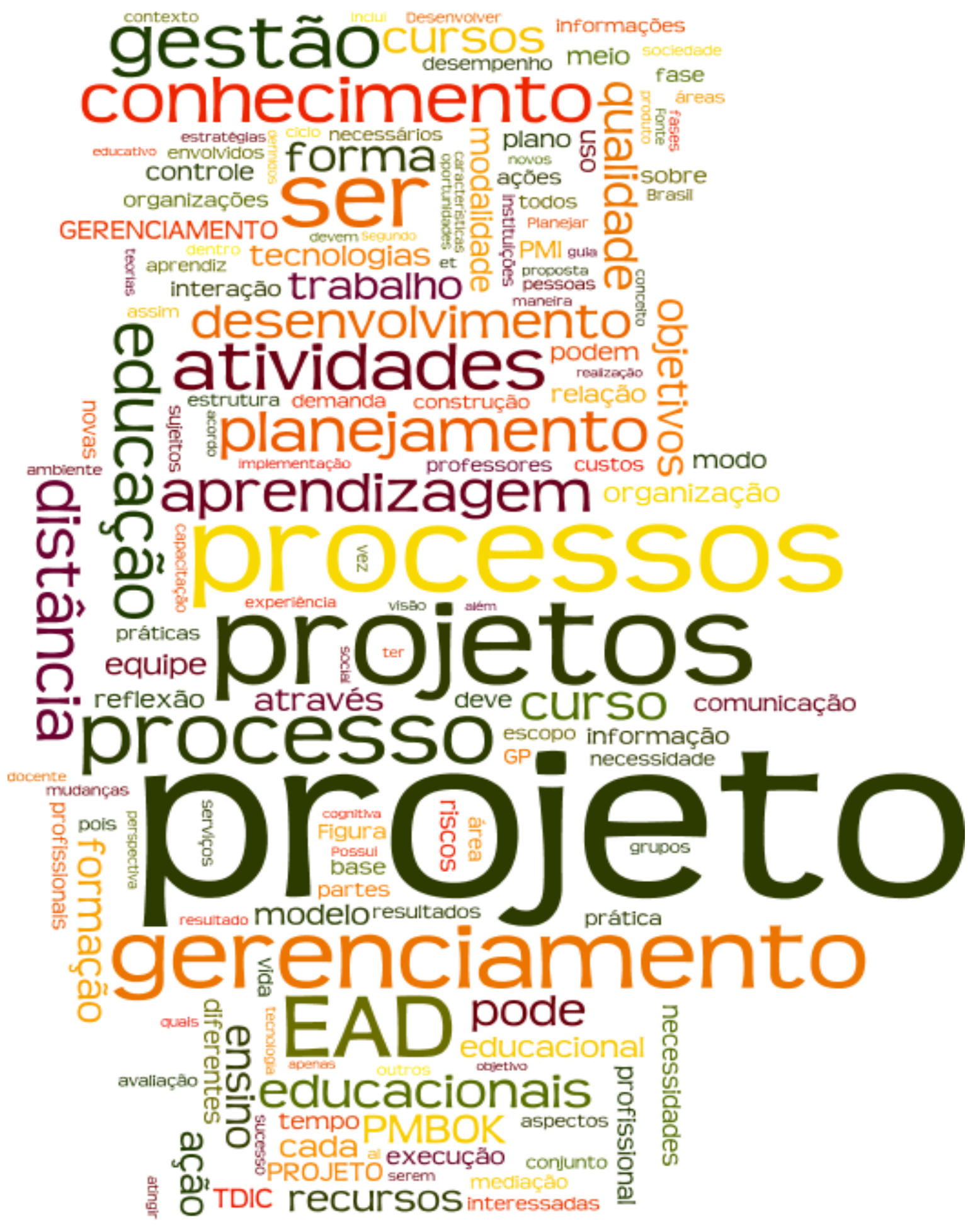

INTRODUÇÃO 


\section{INTRODUÇÃO}

Importantes mudanças socioeconômicas, políticas e tecnológicas ocorreram no Brasil gerando alterações no modo de se fazer educação, dando ênfase na utilização das Tecnologias Digitais de Informação e Comunicação (TDIC), consideradas importantes ferramentas disponíveis para a sociedade contemporânea e amplamente incorporadas na área científica. Tais mudanças refletem no campo do ensino, alterando significativamente a situação da Educação a Distância (EAD) (SILVA, 2014).

Algumas universidades públicas, principais fontes educativas nacionais, contam atualmente com um sistema híbrido de ensino que envolve tanto a educação presencial como a educação a distância, o que possibilita uma modalidade de ação com potenciais novos de utilização de TDIC. Deste modo o Brasil passou de importador de modelos de EAD para desenvolvedores de novos projetos e programas complexos implantados com rapidez (CUNHA, 2015).

De acordo com Maia e Mattar (2007), a educação a distância é praticada nos mais variados setores, como na educação básica, no ensino superior, em universidades abertas, universidades virtuais, treinamento governamentais $e$ empresariais, qualificações docentes, cursos abertos, livres, dentre outros. A EAD tem sido ampliada com a disseminação e uso das TDIC, todavia a crescente oferta de serviços fez com que as atenções recaíssem sobre como os cursos são oferecidos e gerenciados com qualidade (NOVAK, 2002).

No entanto, atribuir total credibilidade a EAD ainda é uma atitude de ousadia no meio acadêmico, principalmente nos processo de formação ou qualificação de professores. Lançar um olhar que ultrapasse a ideia reducionista de tecnificação do processo educativo a distância demanda ampliar o conceito de ensino e aprendizagem para além da escola convencional. Com efeito, não se pode estabelecer uma relação determinista da EAD com as novas tecnologias, pois não são estas que definem a abordagem, ao contrário, é essa modalidade de ensino que se apropria das tecnologias (RODRIGUES, 2011).

Diversos aspectos que tornam o ensino a distância uma modalidade eficiente e eficaz, de acordo com as atuais necessidades da sociedade são a acessibilidade assegurada à coletividade e a autonomia garantida ao aprendiz, 
como o fato de se tornar autodidata e responsável por seu desempenho na trajetória de ampliação de seu conhecimento (DE CARVALHO; BONDIOLI, 2015).

Para Lessa (2011), a EAD caracteriza-se como uma das melhores opções para inclusão social e para a melhoria quantitativa e qualitativa do processo educacional haja vista a limitação do sistema educativo convencional, também denominado de tradicional, de responder as demandas pleiteadas pela evolução dos processos de comunicação.

Considerando a educação em contínua ascensão, há a necessidade de profissionais atualizados e capacitados para um mercado de trabalho competitivo e em busca pela inovação e lucro. Neste ponto, a EAD supre esta demanda e cumpre a missão de fornecer acesso democrático à capacitação acadêmica e qualificação bem como lucro para as instituições de ensino. Observa-se um grande investimento no ensino a distância, haja vista o reconhecimento desta modalidade como um método eficaz para a constituição de novos profissionais, todavia, para que isso seja possível são necessárias infraestrutura adequada de suporte e uma equipe de professores-tutores que garanta o nível da habilitação dos participantes através de um planejamento estratégico específico (LAPA; PRETTO, 2010).

Dentre os investimentos institucionais, tecnológicos e humanos, entende-se que há uma necessária interação entre estes três aspectos para o sucesso da EAD. Embora, seja um método educacional realizado em sua maior parte a distância, os aspectos humanos e gerenciais são cruciais e, também, os que talvez devam ser mais utilizados nesta modalidade, já que a utilização da tecnologia já está implícita, e uma vez que o aprendiz em seu desenvolvimento autônomo é o objetivo final.

$\mathrm{Na}$ EAD há três tipos de abordagens através do uso tecnologias, são elas: o broadcast; a Virtualização da Sala de Aula (VSA) e a Aprendizagem Assistida por Computador (AAC). Na abordagem broadcast, predomina a simples entrega da informação de forma análoga, sem nenhuma interação dos participantes. Na VSA ocorre a transferência do paradigma do espaço-tempo da aula presencial e da comunicação bidirecional existente entre o professor-aluno para o meio virtual. Já na abordagem por AAC, procura-se explorar a potencialidade interativa das TDIC propiciada pela comunicação multidimensional, que aproxima os emissores 
dos receptores dos cursos, permitindo criar condições de aprendizagem e colaboração (ALMEIDA, 2003).

Nessa perspectiva, destaca-se o uso de metodologias que dão ênfase ao processo de ensino, aprendizagem e avaliação ao dar protagonismo aos participantes, colocando-os como agentes proativos, estimulando que busquem respostas para problemas reais e complexos com liberdade e independência, tornando os, assim, corresponsáveis na tomada de decisão, o que gera, consequentemente, uma ruptura com a aprendizagem mecânica e conteudista (COTTA et al., 2013).

Segundo Rodrigues e Barcia (2003), ao se colocar o foco na perspectiva da interferência do aluno sobre a seleção do conteúdo e nas discussões, existem três elementos constitutivos na EAD: o de "Conteúdo com suporte", onde a estrutura básica do curso é produzida em larga escala, devendo ser seguida pelo aprendiz e a possibilidade de contextualização ocorre por meio de interação com os tutores; o "Wrap Around", modelo que tende a incentivar que os aprendizes façam mais pesquisas, gerando mais liberdade e responsabilidade e o papel do tutor é mais intenso, porque uma parcela menor do curso é pré-determinada, de modo que ajustes são feitos a cada vez que o curso é implementado; e o "Integrado" na qual a base possui atividades colaborativas, pesquisas intensivas e projetos em pequenos grupos, com conteúdos fluidos, dinâmicos e determinados pelas atividades individuais ou coletivas, desaparecendo a distinção entre conteúdo e suporte.

No âmbito da relação tempo - espaço - tecnologia, a comunicação digital em interfaces interativas deve ser vista como suporte para que o aprendiz, consciente dos desafios que terá de enfrentar no desenvolvimento de seus estudos a distância e que valorize a prática educativa do professor/tutor em ambiente virtual afim de que este possa mediatizar o ensino/aprendizagem com mais flexibilidade, dando abertura ao diálogo permanente que irá imprimir qualidade ao processo educativo.

De acordo com Alves (2010), a aprendizagem em rede na EAD enfatiza processos colaborativos na medida em que permite ao aprendiz vivenciar distintos papéis e momentos, nos quais a comunicação flui descentralizada, permitindo que 
diferentes vozes sejam ouvidas. A colaboração exige autonomia e não submissão; os sujeitos são pares, coautores nos diferentes processos de criação e reconstrução de sentidos.

Todos esses avanços vêm ao encontro dos objetivos da educação a distância e possibilitam o desenvolvimento de ações educacionais a partir de concepções mais construtivistas do processo de aprendizagem de sujeitos adultos e autônomos. A inserção da tecnologia no processo educativo propiciou 0 desenvolvimento de novas competências cognitivas no usuário de EAD e o potencial interativo do uso das TDIC combinado às diversas habilidades dos aprendizes de interatuar em meio virtual, permitem o desenvolvimento de contatos e atividades por meio de um diálogo altamente participativo (BELLONI, 2009).

Mediatizar, interagir e compartilhar são palavras que ganham expressão quando se trata de contatos virtuais via hipertextos ou outros recursos midiáticos que incentivem os usuários dos sistemas informáticos a promover trocas de informações e transmissão de mensagens pedagógicas por técnicas que caracterizam a educomunicação na era digital (BARBOSA, 2012).

Confiar na possibilidade de transferências sóciocognitivas, impulsionadas pela sociedade da informação, constitui o desenvolvimento da construção do conhecimento, através dos processos andragógicos, compartilhando informações e experiências, fundamentais na permanência e participação dos sujeitos envolvidos na educação a distância. 


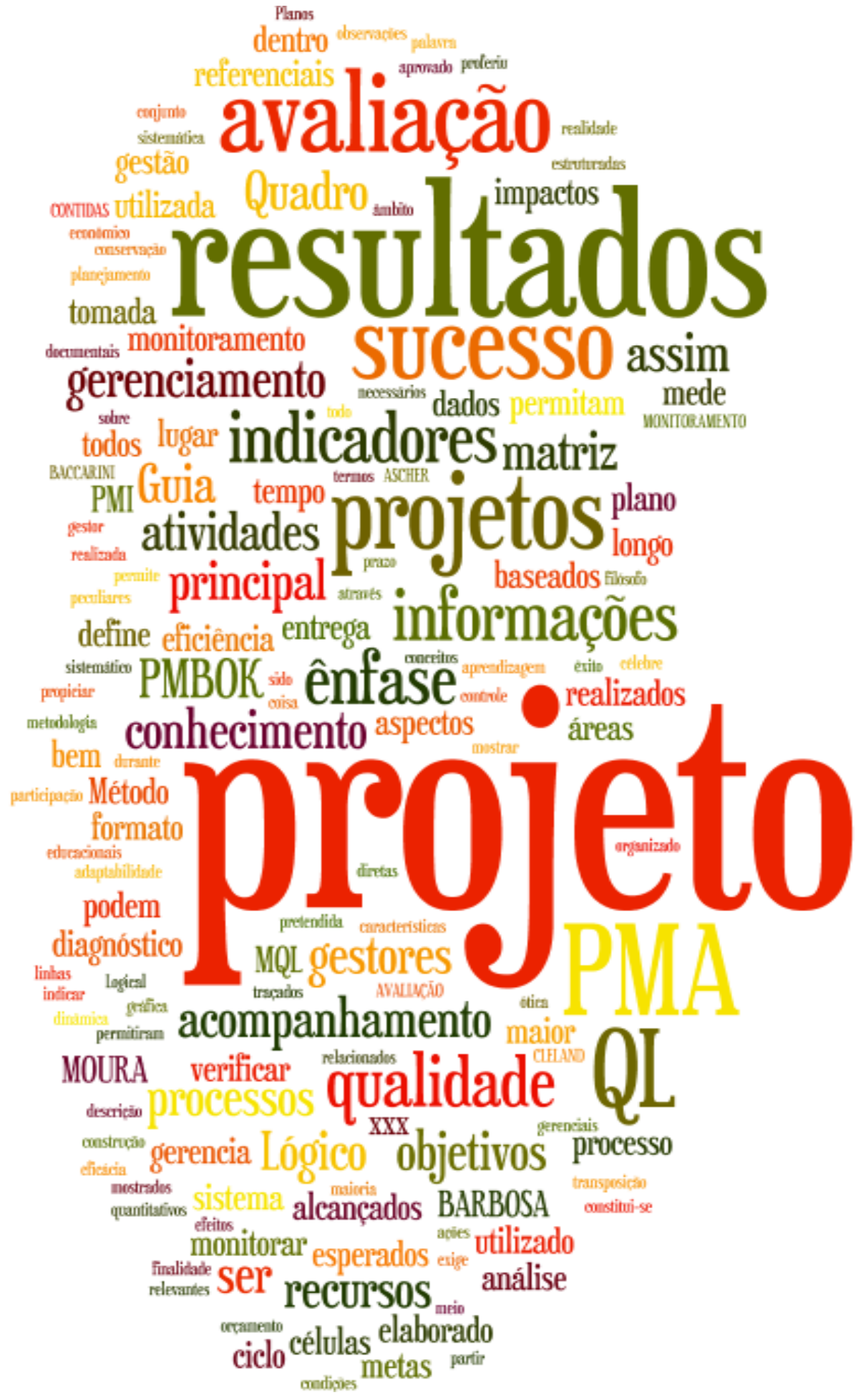

REFERENCIAL TEÓRICO 


\section{REFERENCIAL TEÓRICO}

\subsubsection{Contexto da educação a distância}

Existem vários conceitos de EAD e todos apresentam alguns pontos em comum, entretanto o conceito de educação a distância no Brasil é definido oficialmente no Decreto ㄲo 5.622 de 19 de dezembro de 2005, como a modalidade educacional na qual a mediação didático-pedagógica nos processos de ensino e aprendizagem ocorre com a utilização de meios e tecnologias de informação e comunicação, com estudantes e professores desenvolvendo atividades educativas em lugares ou tempos diversos (BRASIL, 2005).

Ao ampliar-se o conceito de ensino a distância, o foco passa a ser os processos de aprendizagem, considerando também os processos de ensino, pois ambos são importantes e não devem ser pensados de forma segregada, independentemente da modalidade de educação. Refletir conceitos de EAD significa estar disposto a colocar cada elemento em seu lugar e assim não responsabilizar as tecnologias, o aprendiz, professor ou instituição, isoladamente, por todo o processo de aprendizagem (PIMENTEL, 2014).

O governo federal também criou leis e estabeleceu normas para a EAD no Brasil onde os cursos superiores da educação a distância apresentam diplomas com equivalência aos dos cursos oferecidos pelas instituições de ensino superior que utilizam a modalidade presencial, mostrando que a EAD oferece oportunidades similares, ampla abrangência e grandiosa magnitude mundial (UNIFESP, 2009).

Por meio do acesso a EAD, o país proporcionou oportunidades de crescimento e livre concorrência. A consequência da melhora na economia refletiu nos demais segmentos, desenvolveu a indústria, o comércio, e viabilizou os acessos às zonas rurais. É um grande momento para a educação brasileira, pois estão sendo rompidas barreiras ideológicas e novas oportunidades para as classes menos favorecidas são geradas, por meio dessa formação (SOUZA, 2015).

Piconez desde 2008 já argumenta a favor das tecnologias digitais e seu uso educacional através da EAD. Segundo a autora, novas oportunidades geram a necessidade de mudanças no processo de aprender, considerando que a 
possibilidade do uso da mobilidade na aprendizagem consegue envolver alunos, integrar participantes na construção coletiva do aprendizado e incorporar novos conceitos de educação em um mundo repleto de informação e de constante transição.

A EAD vem prosperando, segundo dados do Anuário Brasileiro Estatístico de Educação Aberta a Distância (ABRAED, 2014), e os cursos superiores ofertados a distância tiveram um aumento de $2.588,5 \%$ em paralelo aos cursos presenciais, que tiveram no mesmo período, apenas um acréscimo de 66,9\%. As instituições a distância obtiveram um total de 476.484 matrículas e educandos com faixa etária, em média, entre 21 e 30 anos.

Referente à localização regional e a ampliação destas matrículas, as instituições em sua pluralidade, cresceram percentualmente nas regiões Sudeste $(47 \%)$, seguidas da região Sul e Nordeste (20\% cada) e das regiões Norte $(11,8 \%)$ e Centro-Oeste (10,4\%). Com relação aos obstáculos enfrentados, as instituições asseguram que os maiores foram: a evasão dos estudantes (índice médio de até 25\%), a resistência dos educadores a modalidade EAD e os custos de produção dos cursos, nessa ordem (ABED, 2015).

Este crescimento da EAD deve-se ao fato de hoje, ser a mais democrática das modalidades educacionais, uma vez que elimina, por meio da TDIC, os tradicionais empecilhos à conquista do conhecimento, como isolamento ou distanciamento geográfico dos grandes centros de ensino e aprendizagem, existência de áreas desprovidas de boas oportunidades educacionais, custos adicionais de deslocamento, insuficiente número de vagas, incompatibilidade de horários e impossibilidade de conciliar trabalho e estudo (LESSA, 2011).

Ainda Lesa (2011) complementa que, especificamente na modalidade a distância, na qual a presencialidade e a relação de tempo é modificada e tecnologias adicionais são incorporadas ao processo, para que a aprendizagem aconteça, o aprendiz deve ter ou desenvolver características, como: organização, automotivação, proatividade, determinação e disciplina.

Ainda que na última década inúmeros avanços tenham permeado a história da educação a distância, alguns preconceitos e barreiras precisam ser derrubados. A desconfiança humana e a ignorância social, assim como o desconhecimento de suas possibilidades, reduz o conceito de EAD ao 
elementarismo. Nas diversas regiões nacionais, com persistência, a modalidade de EAD está desfazendo estigmas, instituindo um espaço próprio e complementando o modelo presencial.

Segundo pesquisa realizada pela Associação Brasileira de Treinamento e Desenvolvimento (2014-2015) para investigar a situação das ações de Treinamento e Desenvolvimento (T\&D) no Brasil, 76\% das empresas participantes da pesquisa registraram planejar investir mais recursos em treinamento em 2016, além de terem aumentado o número de horas destinadas a treinamento, para 47 horas anuais, e destas $15 \%$ por EAD. Essa média anual de horas de treinamento é superior aos índices internacionais registrados pelos Estados Unidos da América (30 horas), Europa (36 horas), Austrália (34 horas) e América Latina (31 horas) (ABED, 2015).

Em função da relevância que a educação corporativa assumiu no Brasil, o Ministério do Desenvolvimento, Indústria e Comércio Exterior (MDIC), o Ministério da Educação (MEC) e o Ministério do Trabalho e Emprego (MTE) vem fomentado programas de educação do trabalhador pelas organizações. Além disso, a atualização profissional tem sido impulsionada pela adoção da educação a distância e pelo investimento na ampliação do acesso a oportunidades de aprendizagem profissional continuada.

A tendência de crescimento da oferta de cursos a distância em instituições de ensino e em empresas é um fato, o que resultou em um aumento do número de aprendizes beneficiados por essa modalidade educacional. Programas baseados em EAD para educação, formação, qualificação e treinamento já são uma realidade no Brasil e no mundo. As oportunidades de educação ou treinamento em ambientes abertos de aprendizagem também têm sido oportunizadas por órgãos como SEBRAE, universidades corporativas e instituições de ensino superior (DA SILVA ABBAD, 2007).

Esse contexto demanda o desenvolvimento de políticas educacionais para a formação inicial e continuada a distância com vistas a construir um programa mobilizador de educação e capacitação continuada que defina metas e indicadores de qualidade, criteriosamente selecionados e quantificados, assentados no culto à cidadania, integrando criativamente o binômio educação- 
formação. As instituições de ensino superior, a priori, posicionam-se neste desafio como fóruns de vanguarda de pensamento (PIMENTEL, 2014).

Os dados apresentados despontam a EAD como uma modalidade que promove a inclusão e a democratização do acesso à qualificação profissional. A ampliação de cursos e treinamentos pela educação corporativa são uma prova disso, assim como a diversificação de temáticas abordadas nas áreas de tecnologia, gestão, informática, educação e saúde.

\subsubsection{GESTÃO DA EDUCAÇÃO A DISTÂNCIA}

\subsubsection{Gestão de cursos em educação a distância}

Durante o processo de implantação de cursos EAD, a etapa de planejamento e gerenciamento do curso é um dos temas que vem ocupando as discussões dos envolvidos na projeção e execução das propostas educacionais, muitas vezes com finalidades que excedem o nível do educacional e esbarram também em questões de cunho administrativo e econômico. $O$ fato de que, na educação a distância, se está lidando com sujeitos e instituições de características diversas assim como tecnologias das mais sofisticadas, não tem assegurado igual avanço nos modelos pedagógicos do ensino, e menos ainda, na qualidade da gestão.

De acordo com Araújo e Boullosa (2007), o sujeito habilita-se ao exercício profissional na medida em que complementa seu desenvolvimento teórico com uma vivência profissional de modo intensivo. Assim, não basta apenas realizar cursos para se especializar em uma área do conhecimento, há que se fazer uma incursão por uma vivência prática. Questionamentos como: De que modo a educação a distância impacta no aprendizado? Como avaliar a qualidade de um curso a distância em termos de repercussão e efetividade de treinamento? Como fazer a gestão de um curso em EAD? São apenas alguns dos questionamentos possíveis e que convidam a outros estudos e investigações.

A problemática central da gestão de cursos em EAD está relacionada à dificuldade de se elaborar, de forma científica, um plano de trabalho que realmente atenda as necessidades de todos os entes envolvidos. Pela 
característica plural e pela heterogeneidade de seus alunos, a implementação e manutenção de um curso a distância requer cuidados adicionais. Inúmeros são os fatores que devem ser levados em consideração para que se atenda de maneira satisfatória às necessidades de todos os agentes envolvidos, sejam eles alunos, professores ou dirigentes (RIBEIRO; TIMM; ZARO, 2007).

A criação e manutenção de um curso de EAD exige mais do que uma discussão do melhor modelo pedagógico ou estrutura curricular, exige um adequado gerenciamento a fim de se garantir efetivamente 0 pleno desenvolvimento das atividades dos cursos e da aprendizagem. Esta gestão pode ser entendida, como um processo que permite o desenvolvimento de atividades com eficiência e eficácia, a tomada de decisões com respeito às ações que se fizerem necessárias a escolha e a verificação da melhor forma de executá-las (RUMBLE, 2003).

Em um planejamento sólido, a estrutura, a implementação e a estratégia pedagógica são requisitos para que a educação a distância tenha êxito. Neste sentido, a gestão de um curso demanda garantir que tais aspectos sejam considerados por uma equipe focada em domínios gerenciais fundamentados na gestão de projetos, visando uma ação profícua e a perenidade do curso ao longo do tempo, a qual pressupõe, além de infraestrutura tecnológica, um planejamento eficaz, dinâmico e adequado frente às demandas de atendimento.

Estabelecer um cenário completo e detalhado de funções, atividades, prioridades funcionais e ações estratégicas podem ser a diferença na gestão de uma EAD viável economicamente ou de prejuízo institucional. Apesar das instituições públicas no Brasil não sofrerem a mesma pressão das instituições privadas sobre o retorno dos investimentos financeiros, é possível analisar suas estruturas, em virtude da trajetória histórica da EAD (RIBEIRO et al.,2007).

\subsubsection{Referenciais de qualidade para a educação a distância}

O Ministério da Educação (Brasil, 2007) ressalta que não há um modelo único de educação a distância e os planejamentos podem apresentar diferentes desenhos e múltiplas combinações de linguagens, recursos educacionais e tecnológicos. A natureza do curso e as reais condições do cotidiano e 
necessidades dos estudantes são os elementos que irão definir a melhor tecnologia e metodologia a ser utilizada, visando à qualidade do projeto.

O ínterim evolutivo da EAD evidenciou uma perspectiva de expansão através do governo federal que ponderou alguns indicadores de qualidade da EAD, norteadores a consecução e gerenciamento de um projeto de curso, conforme Quadro 1. Por não possuírem força de lei, as orientações contidas nos indicadores possuem apenas função indutora, não apenas em termos da própria concepção teórico-metodológica, mas também da organização de sistemas de EAD no Brasil.

Quadro 1. Indicadores de qualidade para Educação a Distância.

\begin{tabular}{c|l}
\multicolumn{2}{c}{ INDICADORES } \\
\hline 1 & $\begin{array}{l}\text { Integração com políticas, diretrizes e padrões de qualidade definidos para o } \\
\text { curso específico }\end{array}$ \\
\hline 2 & Desenho do projeto: a identidade da educação a distância \\
\hline 3 & Equipe profissional multidisciplinar \\
\hline 4 & Comunicação/interatividade entre professor e aluno \\
\hline 5 & Qualidade dos recursos educacionais \\
\hline 6 & Infraestrutura de apoio \\
\hline 8 & Avaliação de qualidade contínua e abrangente \\
\hline 9 & Convênios e parcerias \\
\hline 10 & Edital e informações sobre o curso de graduação a distância \\
\hline
\end{tabular}

Fonte: Ministério da Educação, 2007.

Os indicadores elencados não dão conta de todas as necessidades qualitativas de um projeto de EAD, entretanto, novas soluções devem ser construídas caso a caso, impedindo as armadilhas das demandas e dos modelos rígidos. A gestão dos cursos deve ter como característica o fornecimento de soluções flexíveis e customizadas para a instituição, equacionando de maneira precisa a relação custo $x$ benefício, sem perder a visão das questões andragógicas e, principalmente, dos conteúdos complexos e de exigência cognitiva elevada.

Avaliações da qualidade dos cursos na modalidade EAD, segundo Lemak e colaboradores (2005), devem ser pautadas em cinco constructos: Diálogo, 
Estrutura, Tecnologia, Classe e Eficácia. Já Harroff e Valentine (2006) recomendam a avaliação da qualidade dos cursos em EAD com base em outros seis construtos: Instituição, Administração dos Cursos, Informação, Suporte Técnico, Informação para Potenciais Estudantes e Avaliação do Processo.

Menchaca e Bekeleb (2008) também apresentaram uma pesquisa com uma escala de qualidade baseada em cinco fatores: Serviços de suporte; Processos de aprendizagem; fatores relacionados ao curso; características do usuário e fatores relacionados à tecnologia; e recentemente, Pascual e colaboradores (2015) validaram uma escala internacional na Espanha usado sete constructos distintos: Suporte do instrutor; Interação com os estudantes; Relevância pessoal; Aprendizagem autêntica; Aprendizado ativo; Autonomia e Satisfação.

Segundo Cronin e Taylor (2003), o construto "qualidade" é de difícil avaliação, pois ele é formado por outros construtos e quando se fala de serviços, tanto na modalidade presencial como na modalidade EAD, ele se torna mais complexo, já que os serviços são mais difíceis de serem tangibilizados ou percebidos pelo usuário.

Para gerenciar estrategicamente estes indicadores, uma equipe composta por profissionais qualificados, torna-se fundamental para definir, organizar e acompanhar o projeto do curso e o planejamento viável para o mesmo. Também é através da gestão estratégica que se elabora os planos de ação em prol de se alcançar os objetivos estabelecidos e o acompanhamento das etapas, garantindo que todos os aspectos propostos sejam observados (MILL et al.,2010).

O mesmo autor sinaliza que o desenvolvimento de um curso de EAD precisa ser realizado de modo a atender aos padrões aceitáveis pelo cliente interessado, mas ressalta a necessidade de melhoria contínua da qualidade desse produto final. Além disso, a satisfação desses clientes com o produto (conhecimento em construção) move todo o sistema de gestão da qualidade da formação.

A opção epistemológica de um curso a distância pode nortear a proposta de organização em disciplina, módulo, tema, área, reflete a escolha feita pelos sujeitos envolvidos no projeto e seu desenvolvimento. A compreensão de avaliação, os instrumentos a serem utilizados, as concepções de tutor, de cliente, 
de professor, enfim, devem ter coerência com a opção teórico metodológica definida no projeto (BRASIL, 2007).

Para atender às exigências de qualidade nos processos os princípios da interação e da interatividade são fundamentais para o processo de comunicação e devem ser garantidos no uso de qualquer meio tecnológico a ser disponibilizado, da mesma forma que a interação deve ser privilegiada, garantida e fomentada. Além disso, é recomendável que o material didático, desenvolva habilidades e competências específicas, através de um conjunto de mídias compatível com a proposta e com o contexto socioeconômico do público-alvo (BRASIL, 2007).

Em uma conjuntura em que o desenvolvimento e aplicação de qualidade se tornam metas no cerne da EAD, parâmetros avaliativos e investigativos tornam-se necessários para assegurar relevância e garantias de êxito através de dimensões que envolvam o planejamento do projeto do curso, o processo de aprendizagem, a avaliação institucional, a organização andragógica, a gestão acadêmicoadministrativa, a infraestrutura e a sustentabilidade financeira (CARDOSO et al., 2012).

\subsection{GESTÃO DE PROJETOS}

\subsubsection{Definições e características da gestão de projetos}

Segundo Gido e Clements (2007) projeto pode ser definido como um esforço para se atingir um objetivo específico e bem definido por meio de um conjunto único de tarefas interrelacionadas, executado por meio de tarefas independentes. Ruuska e Vartiainen (2003) complementam que o projeto envolve um sistema de trabalho complexo onde elementos técnicos, procedimentais, organizacionais e humanos são integrados. Heldman (2006) argumenta que projetos possuem natureza temporária, com início e fim definidos, concluídos após metas e objetivos cumpridos. Segundo o guia de conhecimento em gerenciamento de projetos, estes podem ser definidos como um empreendimento temporário feito para criar um produto, serviço ou resultado único (PMI, 2013).

Os projetos não são rotineiros, por isso são ditos únicos, e temporários porque possuem começo e fim definidos que frequentemente geram ou 
aprimoram ou suprimem os processos. O Quadro 2 apresenta as diferenças entre projetos e processos.

Quadro 2. Diferenças entre Projetos e Processos.

\begin{tabular}{c|c} 
PROJETOS & PROCESSOS \\
Temporário & Permanente/Contínuo \\
\hline Único/Original & Rotineiro \\
\hline Multifuncional & Funcional \\
\hline Maior grau de incerteza & Maior grau de previsibilidade \\
\hline Foco na integração & Foco na disciplina \\
\hline
\end{tabular}

Fonte: Souza, 2015

A Gestão de Projetos (GP) pode ser definida como a aplicação de conhecimentos, habilidades, ferramentas e técnicas para projetar atividades que visem atingir os requisitos do projeto. A GP envolve criar um equilíbrio entre as demandas de escopo, tempo, custo, qualidade e bom relacionamento com o cliente; seu sucesso está condicionado ao alcance dos seguintes objetivos: entrega dentro do prazo previsto, dentro do custo orçado, com nível de desempenho adequado, aceitação pelo cliente, atendimento de forma controlada às mudanças de escopo e respeito à cultura da organização (PMI, 2013).

Desde 1990 que a busca por estruturações para o gerenciamento de projetos, com foco nas boas práticas de gestão tornou-se incessante, e demandaram guias de conhecimento e processos mais amplos (Body of Knowledge - BoKs) elaborados por instituições e associações de profissionais ligados a área. Destes guias, o mais difundido é o Project Management Body of Knowledge (PMBOK), proposto pelo Project Management Institute (PMI), que, embora tenha uma abordagem americana, está presente em mais de 100 países e é o mais difundido no Brasil.

O Guia PMBOK ressalta que a GP possibilita melhor desempenho e melhores resultados, contribuindo para a criação de uma vantagem competitiva na criação de produtos, serviços ou processos. O interesse na Gestão de Projetos pode ser explicado pela observação de que na era do conhecimento, são as atividades intelectuais que mais adicionam valor aos produtos e serviços. Os empreendimentos ligados a projetos, processos, administração de TDIC, recursos 
humanos, entre outros, estão no grupo de atividades mais importantes para empresas e profissionais que precisam ser competitivos em seus mercados de trabalho (SOUZA, 2015).

As mais diversas organizações estão conseguindo melhorar seus resultados devido à aplicabilidade da GP e consequentemente, sendo consideradas de alto desempenho por obterem mais de $80 \%$ de seus projetos no tempo e orçamento corretos, cumprindo os objetivos iniciais e desperdiçando 13 vezes menos dinheiro (PMI, 2013). A Figura 1 ilustra como os projetos podem trilhar caminhos ou trajetórias escolhidas pela organização para atingir seus objetivos.

Figura 1. Projetos como o caminho para atingir a visão organizacional.

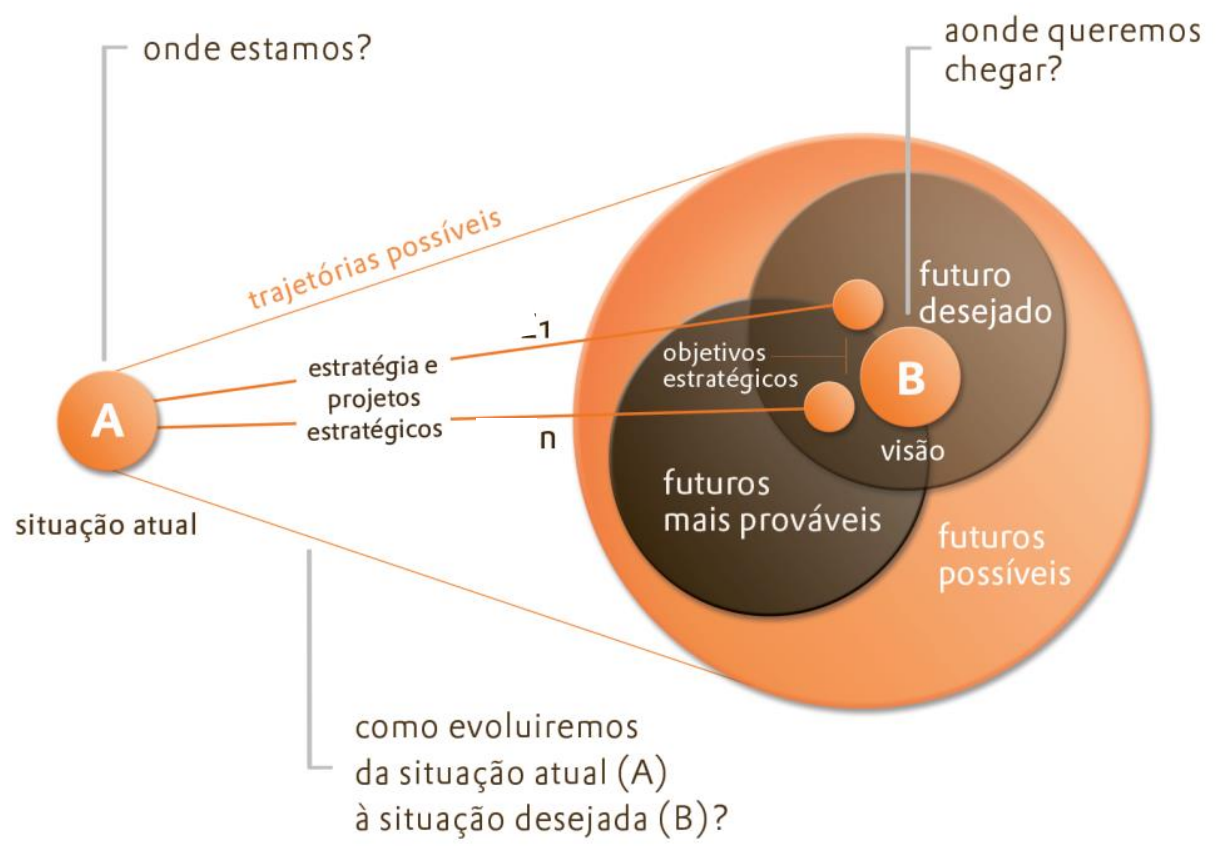

Fonte: http://www.macroplan.com.br/Documentos/Portfolio.pdf

O aumento da percepção e a aceitação do mundo acadêmico e das organizações, dos guias, normas e padrões relacionados à GP, demonstram a necessidade da adoção de métodos formais. Na realidade das organizações, a gestão de projetos constitui o caminho pelo qual as corporações seriam capazes de atingir seus objetivos, através da adoção de métodos de gestão impulsionados por três forças: a demanda cada vez maior por bens e serviços complexos, sofisticados e sob medida; a expansão geométrica do conhecimento; e o 
desenvolvimento de mercados competitivos para a produção e consumo destes bens e serviços (PAPKE-SHIELDS et al., 2010).

Para um melhor controle gerencial, os projetos podem apresentar uma única fase ou serem divididos em fases distintas, também conhecidas como ciclo de vida do projeto. As características do ciclo de vida do projeto visam definir o início e o fim da ideação, determinar quais ações deve ser ou não incluídas ao final das fases ou entre projetos, definir o trabalho ou esforço técnico que deve ser feito em cada etapa; determinar as pessoas que devem estar envolvidas assim como controlar e aprovar cada fase.

De acordo com o Project Management Institute (2013), o ciclo de vida oferece uma estrutura básica para o gerenciamento do projeto, independentemente do trabalho específico envolvido, composto por: início do projeto, organização e preparação, execução do trabalho e encerramento do projeto, como demostrado na Figura 2, quando comparado ao tempo e a intensidade de dedicação ao mesmo.

Figura 2. Estrutura do ciclo de vida de um projeto.

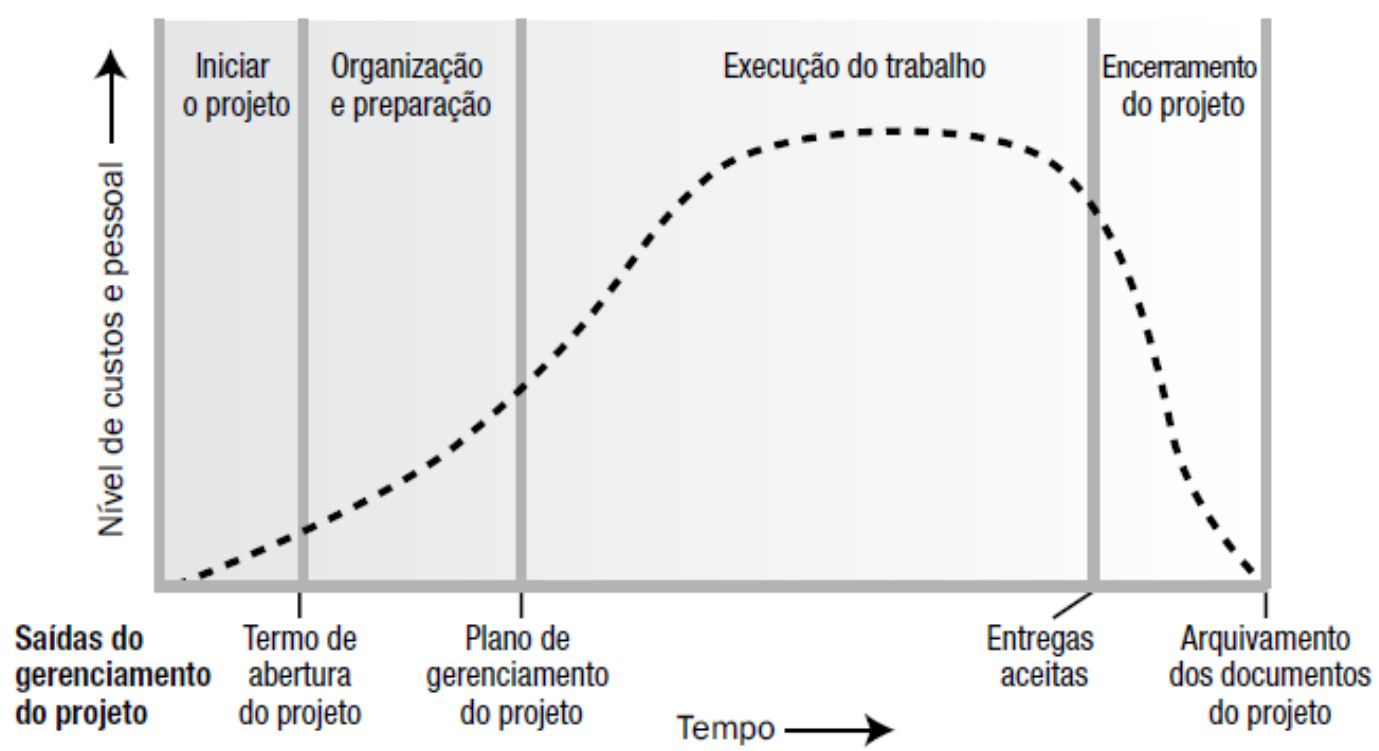

Fonte: PMBOK, 2013.

O ciclo de vida de um projeto pode ser documentado em uma metodologia, oferecendo uma estrutura básica para o gerenciamento, independentemente do trabalho envolvido, definido ou moldado de acordo com o os aspectos exclusivos 
da organização gestora, setor de concentração ou tecnologia empregada (PMI, 2013).

Não existe uma estrutura única que possa ser aplicada a todos os projetos, embora práticas comuns em determinados domínios normalmente levem à utilização de uma estrutura preferida, desmembradas por objetivos funcionais ou parciais, resultados, marcos específicos no escopo geral do trabalho, ou disponibilidade financeira, conforme modelo de exemplo na Figura 3, de ciclo de vida para a realização de um projeto de um curso educacional.

Os modelos de ciclos de vida são comumente usados por pesquisadores e gestores para entenderem como os projetos variam de um ponto no tempo para o próximo, significando também que durante uma determinada fase, alguns requisitos devem ser cumpridos ou não é permitido o projeto passar para a próxima fase (KLOPPENBORG, TESCH \& MANOLIS, 2014).

Com base neste contexto, os projetos educacionais podem ser definidos como empreendimentos de duração finita, objetivos claramente definidos em função de problemas, oportunidades, necessidades, desafios ou interesses de um sistema educacional, de um educador ou grupo de educadores, com a finalidade de planejar, desenvolver, coordenar e executar ações voltadas para melhoria de processos educativos e de formação humana em diferentes níveis (MOURA; BARBOZA, 2013).

Figura 3. Ciclo de vida para realização de um projeto de curso educacional. 


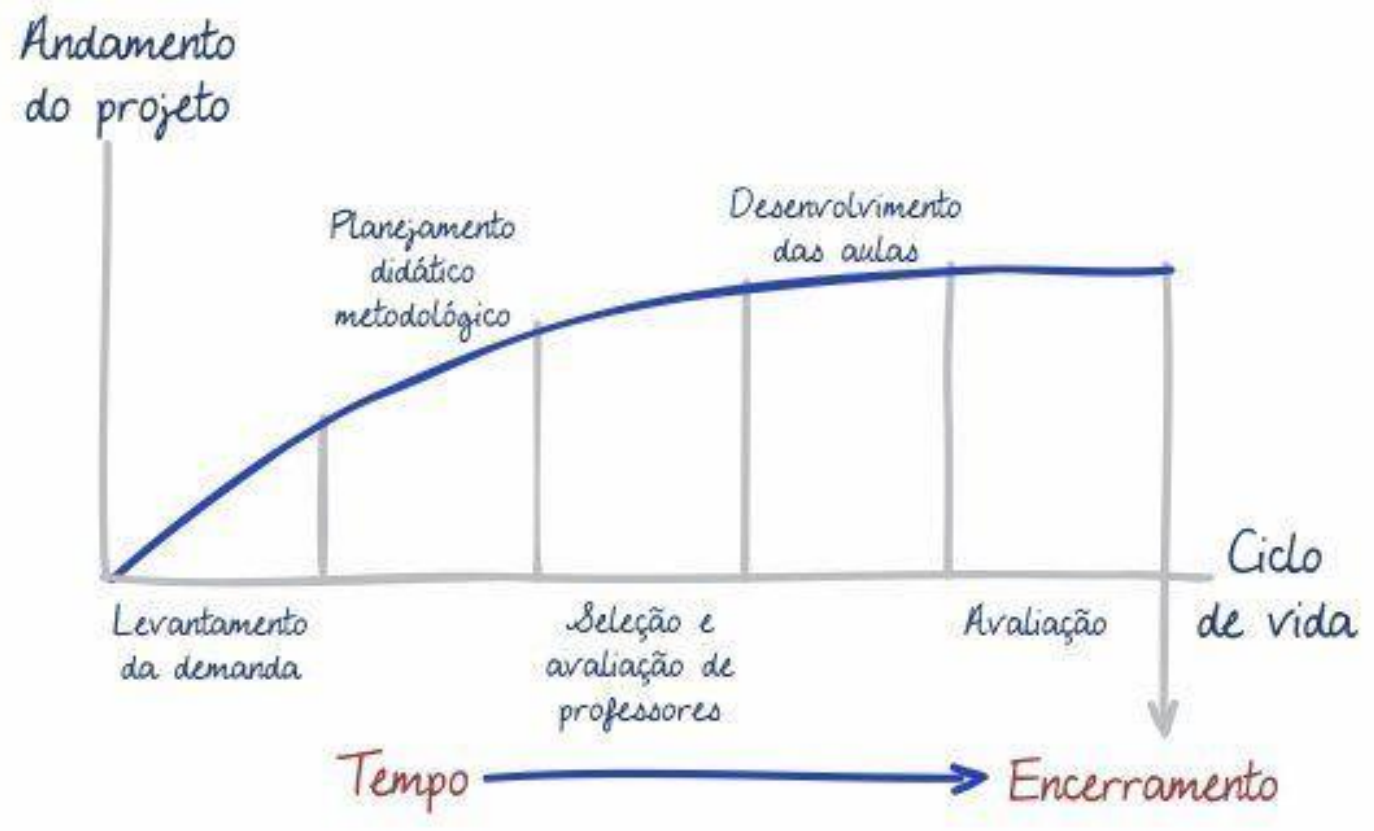

Fonte: Escola Nacional de Administração Pública, 2014.

A base teórica do gerenciamento de projetos pode contribuir na superação das dificuldades na gestão de cursos educacionais, pois a mesma é uma estratégia administrativa moldada a partir da necessidade de executar empreendimentos temporários e exclusivos com diferentes graus de complexidade, buscando atingir o objetivo proposto e visando acompanhar os projetos do início ao fim (QURESHI; WARRAICH; HIJAZI, 2009).

Dentro da estrutura genérica do ciclo de vida do projeto, um gerente de projetos pode determinar a necessidade de um controle mais eficaz, beneficiandose com a divisão formal em fases. A fase de um projeto é um conjunto de atividades relacionadas de maneira lógica que culmina na conclusão do objetivo, permitindo que o projeto seja segmentado em subconjuntos para facilitar o gerenciamento, o planejamento e controle. Alguns projetos podem ter somente uma fase, conforme exibido na Figura 4, e outros projetos podem ter duas ou mais fases, como mostra a Figura 5, que podem ser sequenciadas, uma após a outra, ou mesmo, sobrepostas, onde uma nova fase começa sem a anterior terminar.

Figura 4. Projeto de fase única com um grupo de processos. 


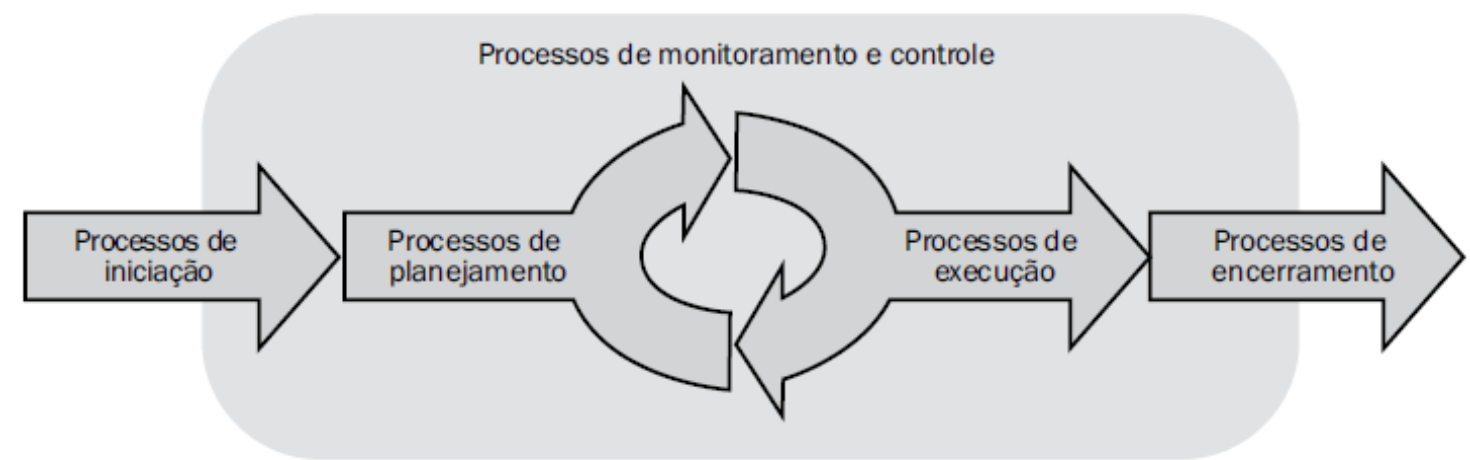

Fonte: PMBOK, 2013.

Quando os projetos incluem várias fases, estas são parte, em geral, de um processo sequencial projetado para garantir o controle apropriado e a obtenção do produto, serviço ou resultado desejado.

Figura 5. Projeto de várias fases com vários grupos de processos.

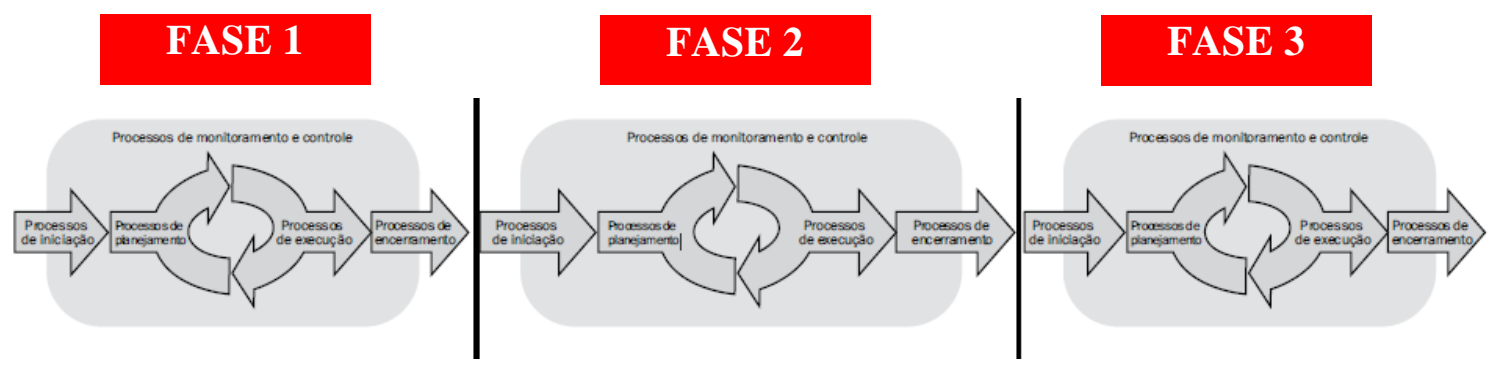

Fonte: PMBOK, 2013.

A universalidade dos processos de gerenciamento de projetos de forma monitorada e ao mesmo tempo, prática, pode enunciar a gradativa evolução da sua conscientização, onde Kerzner (2006) sugere que a gestão de projetos traz, entre outros benefícios, uma maior produtividade, um domínio mais efetivo, decisões mais concisas, adequadas além de respostas mais velozes e melhores resultados.

Projetos de pequeno porte são relativamente fáceis de acompanhar e avaliar, quando se possui um plano de ação bem elaborado e suficiente para fornecer informações essenciais ao acompanhamento das atividades. Da mesma 
forma, a declaração dos objetivos específicos e dos resultados esperados, pode servir para o processo de avaliação (MOURA; BARBOZA, 2013).

Os mesmos autores afirmam que, entretanto, o mesmo não ocorre em projetos educacionais complexos, nos quais o acompanhamento e a avaliação precisam de dados e informações sobre inúmeras atividades e tarefas interdependentes, além de dados e informações sobre resultados do projeto. Nesses casos, torna-se indispensável a adoção de métodos e estratégias de monitoramento e avaliação, visando garantir a efetividade na aplicação dos recursos físicos, humanos e financeiros no desenvolvimento de tais projetos.

Os procedimentos de acompanhamento e avaliação de projetos são conhecidos como Planos de Monitoramento e Avaliação (PMA) ou Sistemas de Monitoramento e Avaliação (SMA). A ideia fundamental que sustenta um PMA é fornecer aos gerentes de projetos um conjunto de recursos metodológicos que facilitem as tarefas de acompanhar o projeto em suas fases e avaliar os resultados (RILLO, 2012).

Um plano de monitoramento e avaliação pode ser construído no momento em que se está elaborando um projeto, no decorrer dele, ou mesmo passado um ciclo. Processos de monitoramento e avaliação estão estreitamente relacionados, pois ambos têm como intenção produzir conhecimento e descrever algum aspecto relacionado ao projeto para a construção de julgamentos, para a tomada de decisão e aprendizagem.

Enquanto o monitoramento ocorre durante a implantação do projeto, processos avaliativos ocorrem em momentos determinados, pontuais, seja ao fim de um ciclo de realização de um projeto, seja após um período predeterminado de tempo. Dessa forma, o monitoramento está relacionado àquelas informações necessárias para o bom andamento do projeto e a avaliação se volta para informações e questões mais abrangentes. Enquanto o monitoramento deve cobrir poucas e essenciais informações, a avaliação pode englobar um conjunto de procedimentos de coleta, uma investigação mais robusta que enfoque mais minúcias e detalhes das causas de cada resultado alcançado ou das deficiências encontradas (INSTITUTO FONTE, 2012).

O PMA é considerado como peça central do ciclo de projetos. Contudo, a implementação de um plano completo de monitoramento que inclua um 
cronograma de atividades de monitoramento, com dimensionamento de custos e responsabilidades, é usualmente negligenciada nos projetos. Os indicadores muitas vezes não são nem mesmo aplicados, e quando são não geram informação de qualidade para que os projetos possam fazer ajustes de rumos, retroalimentar seus processos de planejamento e mesmo refletir sobre os problemas que porventura estejam dificultando o alcance dos seus objetivos (ASCHER; GUIMARÃES, 2004).

Atualmente, tem-se dado ênfase ao monitoramento centrado na aprendizagem coletiva e na maximização dos impactos positivos gerados pelos projetos. A mudança do foco do monitoramento do controle externo, voltado para prestação de contas aos financiadores, para um processo interno de aprendizagem, no qual o foco está na geração de conhecimento, altera não só os instrumentos usados como os resultados (ASCHER; GUIMARÃES, 2004).

\subsubsection{Grupos de processos na gestão de projetos}

O projeto, durante sua gestão passa por diferentes estágios como os de concepção, planejamento, programação, execução, monitoramento, controle, avaliação e término. Dependendo do escopo, cada projeto poderá ter uma ou mais fases e dentro de cada fase, o Guia PMBOK, uma referência na gestão de projetos, define cinco grupos de processos do gerenciamento do projeto que na maior parte do tempo se entrelaçam: iniciação, planejamento, execução, monitoramento e controle e encerramento, conforme Figura 6 (PMI, 2013).

No encadeamento de cada fase, o Guia PMBOK caracterizada estes 5 grupos de processos por um conjunto de atividades distintas e interligadas, das quais resultam diferentes produtos correspondentes. O resultado de um geralmente se torna base de início de outro. Entre grupos de processos centrais essas ligações são repetidas de modo que o processo de planejamento fornece ao processo de execução um plano de projeto documentado e, depois, fornece atualizações documentadas ao plano durante o projeto. 
Figura 6. Grupos de processos de gerenciamento de projetos.

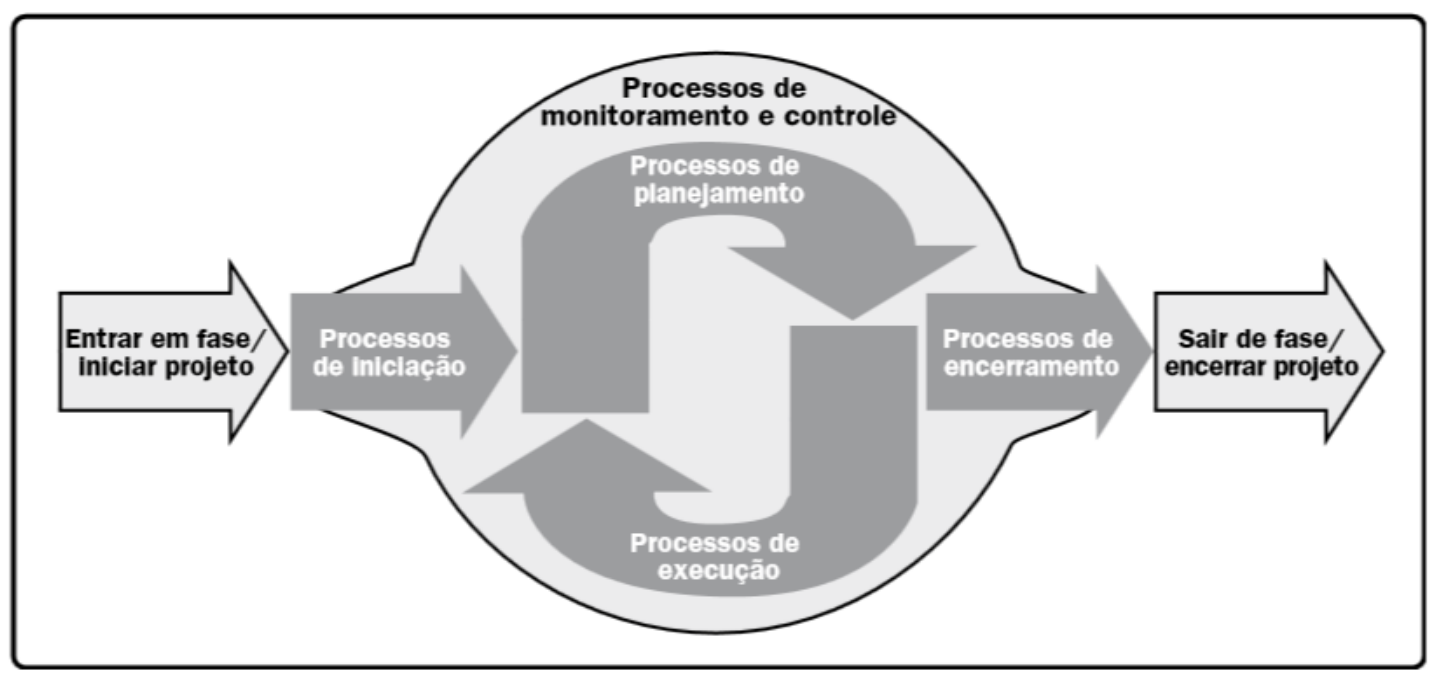

Fonte: PMBOK, 2013.

No processo de iniciação é desenvolvida a visão geral do projeto, ou seja, será verificado se o projeto deve ser realizado, identificado o problema ou a situação geradora, determinado o que será feito e definida sua abrangência. No processo de planejamento ficarão definidos os objetivos, os resultados esperados, os recursos, a estimativa de custos e prazos. Neste momento será detalhado o escopo do projeto, listadas as atividades e tarefas necessárias aos resultados desejados, sequenciada as atividades e definido um cronograma para cada atividade programada. No processo de execução serão organizadas e coordenadas as equipes de modo a atribuir tarefas, resolver conflitos, mantendo uma comunicação efetiva para garantir o planejamento inicial.

O processo de monitoramento e controle consiste na realização do acompanhamento do projeto para que não ocorram desvios em relação ao plano, adotando ações corretivas para manter o curso planejado, reescalonando as atividades quando necessário e adequando recursos disponíveis. No encerramento serão avaliados os resultados, verificando e analisando os objetivos alcançados, elaborando relatórios finais, disseminando os resultados e consolidando o aprendizado, assim como formulando novas propostas para projetos vindouros. Os grupos de processos estão ligados pelos resultados que produzem e o resultado de um geralmente se torna base de início de outro. 


\subsubsection{Grupos de processos e áreas de conhecimento no PMBOK}

Os processos de gerenciamento identificados no Guia PMBOK são também agrupados em dez áreas de conhecimento distintas totalizando 47 processos agrupados em cinco grupos de processos. Cada área de conhecimento representa um conjunto completo de conceitos, termos e atividades que compõem um campo profissional, campo de gerenciamento de projetos, ou uma área de especialização. As áreas de conhecimento estão descritas no quadro 3 e em seguida no quadro 4 estão mapeadas por grupo de processos, onde são apresentados no grupo em que a maior parte das atividades ocorre.

Quadro 3. Áreas de conhecimento do PMBOK.

\begin{tabular}{|c|c|}
\hline \multicolumn{2}{|c|}{ ÁREAS DE CONHECIMENTO } \\
\hline $\begin{array}{l}\text { GERENCIAMENTO DA } \\
\text { INTEGRAÇÃO DO } \\
\text { PROJETO }\end{array}$ & $\begin{array}{l}\text { Inclui processos e atividades para identificar, } \\
\text { definir, combinar, unificar e coordenar os vários } \\
\text { processos e atividades dentro dos grupos de } \\
\text { processos de gerenciamento de projetos. } \\
\text { Possui } 6 \text { processos. }\end{array}$ \\
\hline $\begin{array}{l}\text { GERENCIAMENTO DO } \\
\text { ESCOPO DO PROJETO }\end{array}$ & $\begin{array}{c}\text { Inclui processos necessários para assegurar } \\
\text { que o projeto inclui todo o trabalho necessário } \\
\text { para terminar o projeto com sucesso. Está } \\
\text { relacionado principalmente com a definição e } \\
\text { controle do que está e do que não está incluso } \\
\text { no projeto. Possui } 6 \text { processos. }\end{array}$ \\
\hline $\begin{array}{l}\text { GERENCIAMENTO DO } \\
\text { TEMPO DO PROJETO }\end{array}$ & $\begin{array}{l}\text { Inclui processos necessários para gerenciar o } \\
\text { término pontual do projeto. Possui } 7 \text { processos. }\end{array}$ \\
\hline $\begin{array}{l}\text { GERENCIAMENTO DOS } \\
\text { CUSTOS DO PROJETO }\end{array}$ & $\begin{array}{l}\text { Inclui processos envolvidos em planejamento, } \\
\text { estimativas, orçamentos, financiamentos, } \\
\text { gerenciamento e controle de custos, de modo } \\
\text { que o projeto possa ser terminado dentro do } \\
\text { orçamento aprovado. Possui } 4 \text { processos. }\end{array}$ \\
\hline $\begin{array}{l}\text { GERENCIAMENTO DA } \\
\text { QUALIDADE DO } \\
\text { PROJETO }\end{array}$ & $\begin{array}{l}\text { Inclui processos e atividades da organização } \\
\text { executora que determinam as políticas, os } \\
\text { objetivos e as responsabilidades, de modo que } \\
\text { o projeto satisfaça às necessidades para as } \\
\text { quais foi empreendido. Possui } 3 \text { processos. }\end{array}$ \\
\hline $\begin{array}{l}\text { GERENCIAMENTO DOS } \\
\text { RECURSOS HUMANOS } \\
\text { DO PROJETO }\end{array}$ & $\begin{array}{l}\text { Inclui processos que organizam, gerenciam e } \\
\text { guiam a equipe do projeto. A equipe do projeto } \\
\text { consiste das pessoas com papéis e } \\
\text { responsabilidades designadas para completar o }\end{array}$ \\
\hline
\end{tabular}




\begin{tabular}{|c|c|}
\hline & projeto. Possui 4 processos. \\
\hline $\begin{array}{c}\text { GERENCIAMENTO DAS } \\
\text { COMUNICAÇÕES DO } \\
\text { PROJETO }\end{array}$ & $\begin{array}{c}\text { Inclui processos necessários para assegurar } \\
\text { que as informações do projeto sejam } \\
\text { planejadas, coletadas, criadas, distribuídas, } \\
\text { armazenadas, recuperadas, gerenciadas, } \\
\text { controladas, monitoradas e finalmente dispostas } \\
\text { de maneira oportuna e apropriada. Possui } 3 \\
\text { processos. }\end{array}$ \\
\hline $\begin{array}{l}\text { GERENCIAMENTO DOS } \\
\text { RISCOS DO PROJETO }\end{array}$ & $\begin{array}{c}\text { Inclui processos de planejamento, identificação, } \\
\text { análise, planejamento de respostas e controle } \\
\text { de riscos de um projeto. Os objetivos do } \\
\text { gerenciamento de riscos do projeto são } \\
\text { aumentar a probabilidade e o impacto dos } \\
\text { eventos positivos e reduzir a as dos eventos } \\
\text { negativos. Possui } 6 \text { processos. }\end{array}$ \\
\hline $\begin{array}{l}\text { GERENCIAMENTO DAS } \\
\text { AQUISIÇÕES DO } \\
\text { PROJETO }\end{array}$ & $\begin{array}{c}\text { Inclui processos necessários para comprar ou } \\
\text { adquirir produtos, serviços ou resultados } \\
\text { externos à equipe do projeto. A organização } \\
\text { pode ser tanto o comprador quanto o vendedor } \\
\text { de produtos, serviços ou resultados de um } \\
\text { projeto. Possui } 4 \text { processos }\end{array}$ \\
\hline $\begin{array}{c}\text { GERENCIAMENTO DAS } \\
\text { PARTES INTERESSADAS } \\
\text { DO PROJETO }\end{array}$ & $\begin{array}{c}\text { Inclui processos exigidos para identificar todas } \\
\text { as pessoas, grupos ou organizações que podem } \\
\text { impactar ou serem impactados pelo projeto, } \\
\text { analisar as expectativas das partes interessadas } \\
\text { e seu impacto no projeto, e desenvolver } \\
\text { estratégias de gerenciamento apropriadas para } \\
\text { o engajamento eficaz das partes interessadas } \\
\text { nas decisões e execução do projeto. Possui } 4 \\
\text { processos. }\end{array}$ \\
\hline
\end{tabular}

Fonte: Adaptado de PMI (2013).

Como elementos de apoio, as áreas de conhecimento fornecem uma descrição detalhada das entradas e saídas do processo e uma explicação descritiva das ferramentas e técnicas usadas com maior frequência nos processos de gerenciamento de projetos para produzir cada resultado. Um diagrama de fluxo de dados é fornecido em cada área de conhecimento (Figura 8), com uma visão resumida dos processos que fluem por todos os grupos de processos dentro de uma área de conhecimento específica. Embora os processos sejam apresentados como elementos distintos com interfaces bem definidas, na prática eles são iterativos e podem se sobrepuser e interagir (PMBOK, 2013). 
Figura 8. Fluxo de processos e áreas de conhecimento.

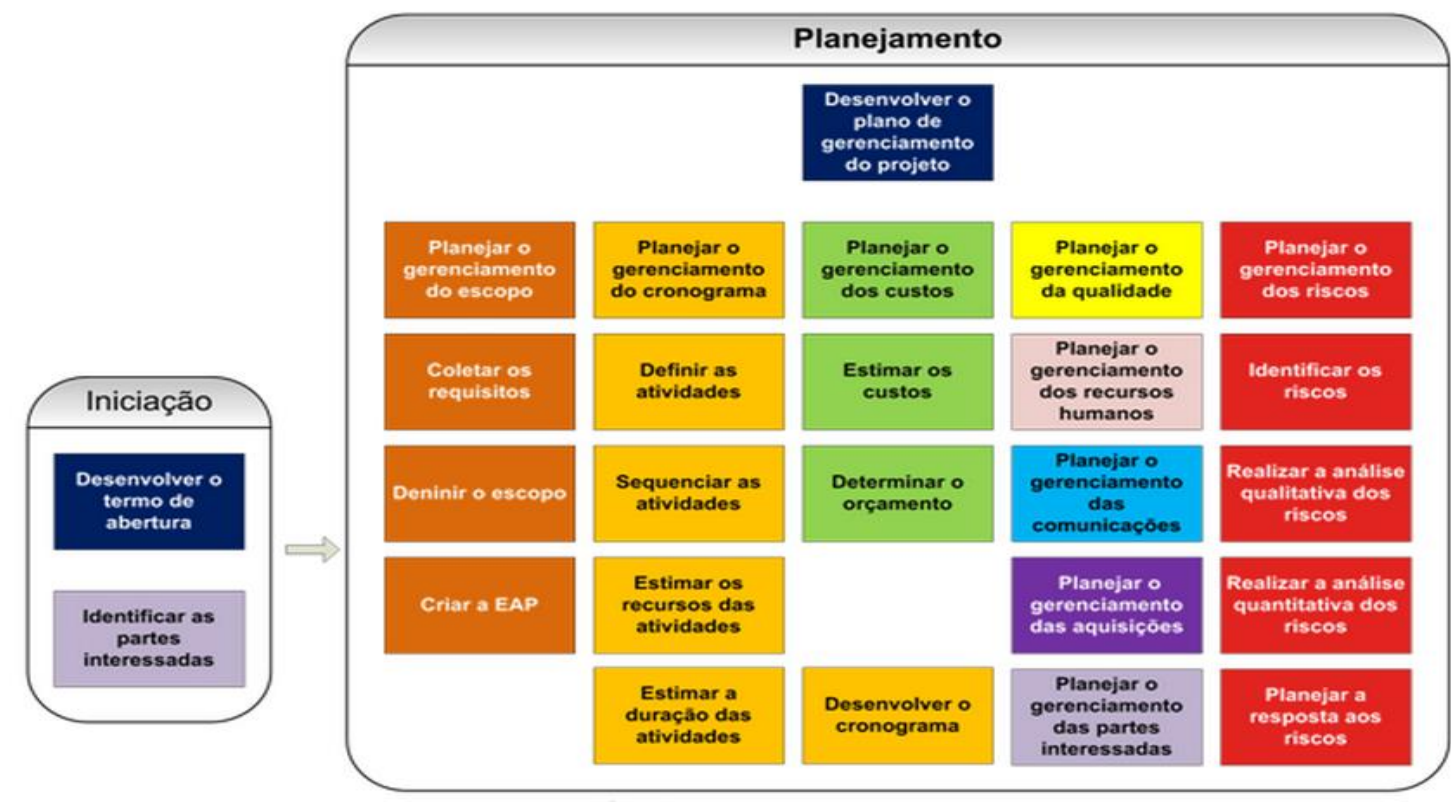

نூ

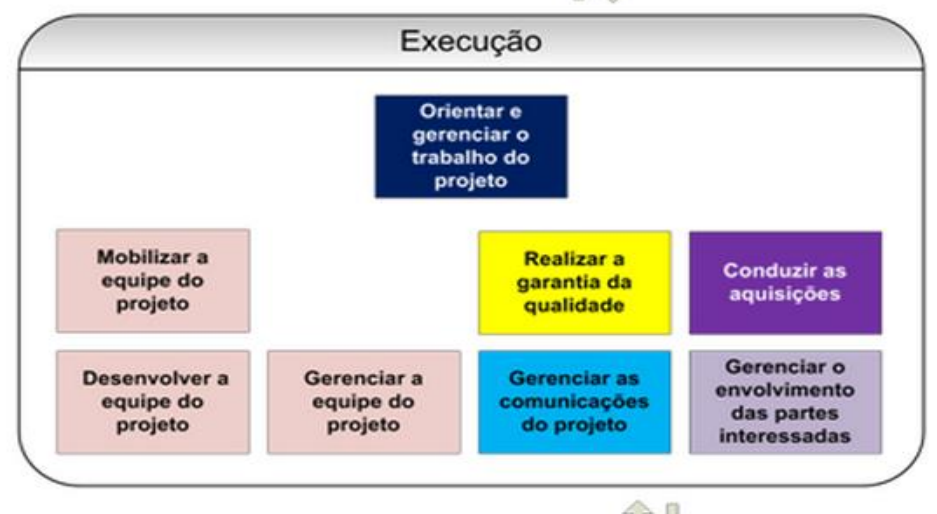

ญ』

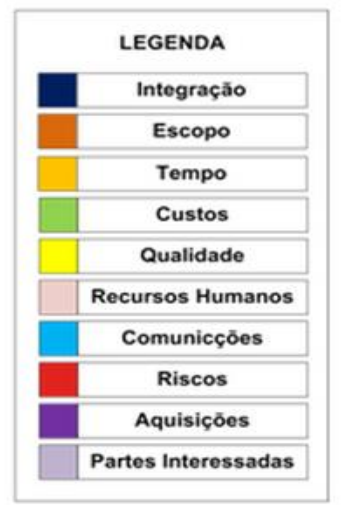

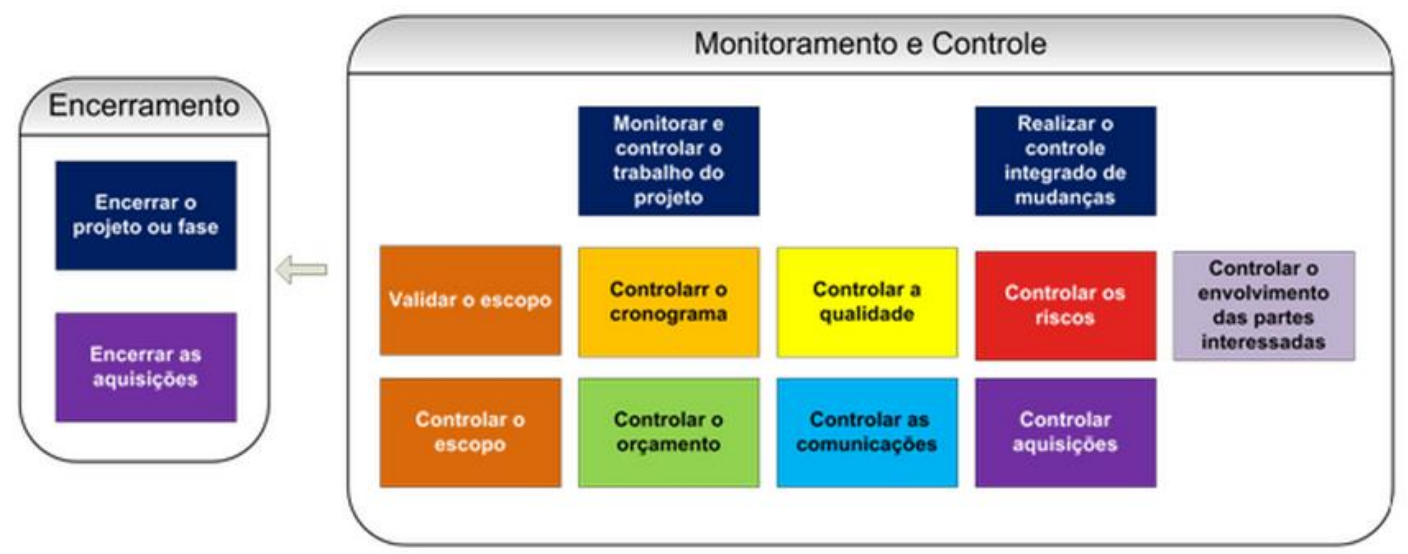

Fonte: Adaptado do Guia PMBOK, 2013. 
Quadro 4. Grupo de processos de gerenciamento de projetos e mapeamento das áreas de conhecimento.

\begin{tabular}{|c|c|c|c|c|c|}
\hline $\begin{array}{c}\text { ÁREAS DE } \\
\text { CONHECIMENTO }\end{array}$ & $\begin{array}{l}\text { Grupo de } \\
\text { processos de } \\
\text { INICIAÇÃO }\end{array}$ & $\begin{array}{c}\text { Grupo de } \\
\text { processos de } \\
\text { PLANEJAMENTO }\end{array}$ & $\begin{array}{l}\text { Grupo de } \\
\text { processos de } \\
\text { EXECUÇẪO }\end{array}$ & $\begin{array}{l}\text { Grupo de processos } \\
\text { de } \\
\text { MONITORAMENTO E } \\
\text { CONTROLE }\end{array}$ & $\begin{array}{c}\text { Grupo de } \\
\text { processos de } \\
\text { ENCERRAMENTO }\end{array}$ \\
\hline $\begin{array}{l}\text { GERENCIAMENTO } \\
\text { DA INTEGRAÇÃO } \\
\text { DO PROJETO }\end{array}$ & $\begin{array}{l}\text { Desenvolver } \\
\text { o tempo de } \\
\text { abertura do } \\
\text { projeto. }\end{array}$ & $\begin{array}{l}\text { Desenvolver o } \\
\text { plano de } \\
\text { gerenciamento } \\
\text { do projeto. }\end{array}$ & $\begin{array}{c}\text { Orientar e } \\
\text { gerenciar o } \\
\text { trabalho do } \\
\text { projeto. }\end{array}$ & $\begin{array}{c}\text { Monitorar e } \\
\text { controlar o trabalho } \\
\text { do projeto; Realizar } \\
\text { o controle integrado } \\
\text { de mudanças. }\end{array}$ & $\begin{array}{c}\text { Encerrar o projeto } \\
\text { ou fase. }\end{array}$ \\
\hline $\begin{array}{l}\text { GERENCIAMENTO } \\
\text { DO ESCOPO DO } \\
\text { PROJETO }\end{array}$ & & $\begin{array}{c}\text { Planejar o } \\
\text { escopo; Coletar } \\
\text { os requisitos; } \\
\text { Definir o escopo; } \\
\text { Criar a estrutura } \\
\text { analítica do } \\
\text { projeto. }\end{array}$ & & $\begin{array}{l}\text { Validar o escopo; } \\
\text { Controlar o escopo. }\end{array}$ & \\
\hline $\begin{array}{l}\text { GERENCIAMENTO } \\
\text { DO TEMPO DO } \\
\text { PROJETO }\end{array}$ & & $\begin{array}{l}\text { Planejar o } \\
\text { cronograma; } \\
\text { Definir as } \\
\text { atividades; } \\
\text { Estimar os } \\
\text { recursos; Estimar } \\
\text { a duração das } \\
\text { atividades; } \\
\text { Desenvolver o } \\
\text { cronograma. }\end{array}$ & & $\begin{array}{l}\text { Controlar o } \\
\text { cronograma. }\end{array}$ & \\
\hline $\begin{array}{c}\text { GERENCIAMENTO } \\
\text { DOS CUSTOS DO } \\
\text { PROJETO }\end{array}$ & & $\begin{array}{l}\text { Planejar e } \\
\text { Estimar os } \\
\text { custos; } \\
\text { Determinar o } \\
\text { orçamento. }\end{array}$ & & Controlar os custos. & \\
\hline $\begin{array}{c}\text { GERENCIAMENTO } \\
\text { DA QUALIDADE DO } \\
\text { PROJETO }\end{array}$ & & $\begin{array}{c}\text { Planejar o } \\
\text { gerenciamento } \\
\text { da qualidade. }\end{array}$ & $\begin{array}{l}\text { Realizar a } \\
\text { garantia da } \\
\text { qualidade. }\end{array}$ & $\begin{array}{l}\text { Controlar a } \\
\text { qualidade. }\end{array}$ & \\
\hline $\begin{array}{c}\text { GERENCIAMENTO } \\
\text { DOS RECURSOS } \\
\text { HUMANOS DO } \\
\text { PROJETO }\end{array}$ & & $\begin{array}{c}\text { Planejar o } \\
\text { gerenciamento } \\
\text { dos recursos } \\
\text { humanos. }\end{array}$ & $\begin{array}{l}\text { Mobilizar a } \\
\text { equipe do } \\
\text { projeto; } \\
\text { Desenvolver a } \\
\text { equipe; } \\
\text { Gerenciar a } \\
\text { equipe. }\end{array}$ & & \\
\hline $\begin{array}{l}\text { GERENCIAMENTO } \\
\text { DOS RECURSOS DE } \\
\text { COMUNICAÇÕES } \\
\text { DO PROJETO }\end{array}$ & & $\begin{array}{c}\text { Planejar o } \\
\text { gerenciamento } \\
\text { das } \\
\text { comunicações. }\end{array}$ & $\begin{array}{c}\text { Gerenciar as } \\
\text { comunicações. }\end{array}$ & $\begin{array}{l}\text { Controlar as } \\
\text { comunicações. }\end{array}$ & \\
\hline $\begin{array}{c}\text { GERENCIAMENTO } \\
\text { DOS RISCOS DO } \\
\text { PROJETO }\end{array}$ & & $\begin{array}{c}\text { Planejar e } \\
\text { Identificar os } \\
\text { riscos; Realizar a } \\
\text { análise qualitativa } \\
\text { e quantitativa dos } \\
\text { riscos; Planejar } \\
\text { as respostas aos } \\
\text { riscos. }\end{array}$ & & Controlar os riscos. & \\
\hline
\end{tabular}




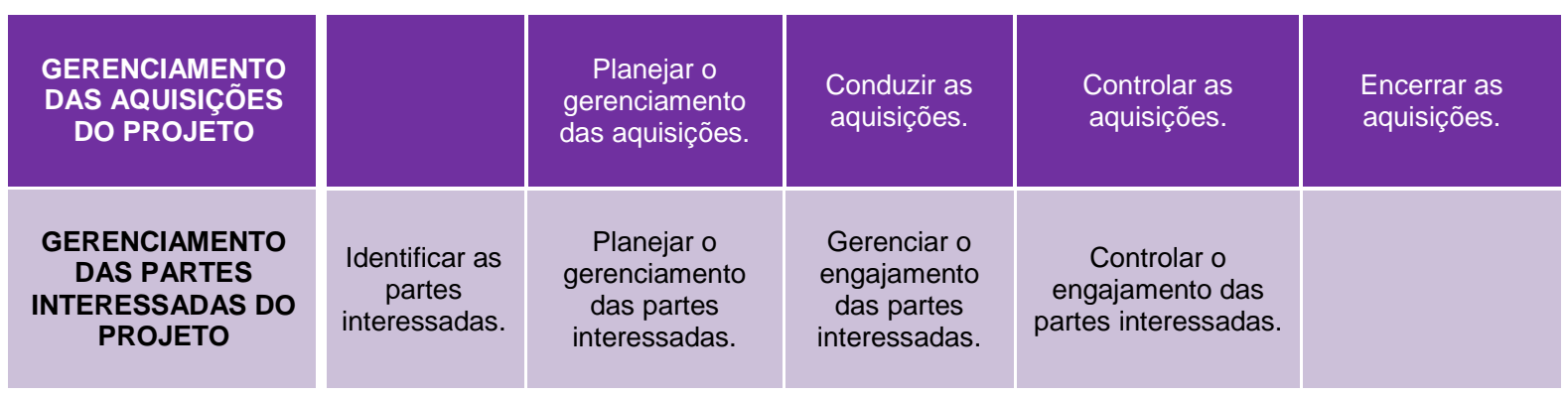

Fonte: Adaptado de PMI (2013).

\subsection{4 Áreas de conhecimento no PMBOK}

O gerenciamento da integração inclui ações necessárias para definir e coordenar os vários processos e atividades dos grupos de processos de gerenciamento, tais como: 1. Desenvolver documentos que formalizem o projeto ou uma fase e documente seus requisitos iniciais para satisfazer as necessidades e expectativas dos stakeholders (pessoas ou organizações, interessadas e envolvidas no projeto); 2. Desenvolver o plano de gerenciamento do projeto; 3. Realizar o trabalho do plano de gerenciamento do projeto, para atingir seus objetivos; 4. Monitorar e revisar o progresso, para atendimento dos objetivos de desempenho definidos; 5. Revisar, aprovar e gerir as solicitações de mudança nas entregas, documentos e plano de gerenciamento do projeto; 6. Finalizar as atividades para formalizar o término do projeto ou uma fase.

O gerenciamento do escopo assegura que todo o trabalho necessário para finalização do projeto esteja descrito, como: 1. Criar um plano de gerenciamento do escopo do projeto que documenta como tal escopo será definido, validado e controlado; 2. Documentar as necessidades dos stakeholders para atingir os objetivos do projeto; 3. Descrever detalhadamente o projeto e o seu produto; 4. Subdividir as entregas e o trabalho do projeto em componentes menores e mais facilmente gerenciáveis; 5. Aceitar as entregas concluídas do projeto; 6. Monitorar o progresso do escopo e produto do projeto além de gerir as mudanças praticadas.

O gerenciamento do tempo gerencia o término do projeto, desenvolvendo ações de: 1. Estabelecimento de políticas, procedimentos e documentação para o planejamento, desenvolvimento, gerenciamento, execução e controle do cronograma do projeto. 2. Identificação das ações a serem realizadas para produzir as entregas do projeto; 3. Identificação e documentação dos 
relacionamentos entre as atividades do projeto; 4. Estimativa dos tipos e quantidades de material, pessoas, equipamentos ou suprimentos que serão necessários para realizar cada atividade; 5 . Estimativa do número de períodos de trabalho que serão necessários para terminar atividades específicas com os recursos previstos; 6. Análise das sequências das atividades, durações, recursos necessários e restrições visando a criação do cronograma; 7. Monitoramento do andamento do projeto, para atualização do seu progresso e gestão das mudanças feitas no cronograma.

O gerenciamento dos custos abarca os processos envolvidos em cálculos e controle dos custos, de modo que o mesmo possa ser terminado dentro do orçamento aprovado, que em síntese são: 1. Estabelecer as políticas, os procedimentos e a documentação para o planejamento, gestão, despesas e controle dos custos do projeto; 2. Desenvolver de uma avaliação de custos dos recursos monetários necessários para concluir as atividades do projeto; 3 . Agregação dos custos estimados de atividades individuais ou pacotes de trabalho, para estabelecer uma linha de base dos custos; 4. Monitoramento do orçamento do projeto e gerenciamento das mudanças feitas na linha de base dos custos.

O gerenciamento da qualidade contém os processos e as atividades que determinam as políticas de qualidade, os objetivos e as responsabilidades, de modo que o projeto convenha às necessidades para as quais foi empreendido, portanto envolve: 1. Identificar os requisitos de qualidade do projeto e do produto, bem como documentar de que modo demonstrará a conformidade; 2. Auditar dos requisitos de qualidade das medições de controle da mesma, para garantir que sejam usados os padrões e definições operacionais apropriados; 3. Monitorar e registrar as atividades de qualidade, para avaliação do desempenho e recomendação das mudanças necessárias.

O gerenciamento dos recursos humanos organiza e gerencia a equipe do projeto, de forma a: 1. Determinar e documentar de funções, responsabilidades, habilidades necessárias e relações hierárquicas do projeto, além de criar um plano de gerenciamento do pessoal; 2. Confirmar a disponibilidade de pessoal e formação da equipe necessária para concluir as designações do projeto; 3. Melhorar as competências, interação da equipe e ambiente global da equipe, para aprimorar o desempenho do projeto; 4. 
Acompanhar o desempenho de membros da equipe, fornecer feedback, resolver questões e gerenciar mudanças para aperfeiçoar o desempenho do projeto.

O gerenciamento das comunicações assegura que as informações do projeto sejam geradas, coletadas, distribuídas, armazenadas, recuperadas e organizadas de maneira apropriada, de forma a: 1. Desenvolver uma abordagem apropriada e um plano de comunicações do projeto com base nas necessidades de informação e requisitos das partes interessadas; 2. Criar, coletar, distribuir, armazenar, recuperar e dispor as informações do projeto de acordo com o plano de gerenciamento das comunicações; 3. Monitorar e controlar as comunicações no decorrer de todo o ciclo de vida do projeto para assegurar que as necessidades de informação das partes interessadas do projeto sejam atendidas.

O gerenciamento dos riscos abrange os processos de planejamento, identificação, análise, planejamento de respostas, monitoramento e controle de riscos, com foco na: 1. Descrição de como reger as atividades de gerenciamento dos riscos de um projeto; 2. Determinação dos riscos do projeto e sua documentação; 3. Priorização dos riscos para avaliação de probabilidade de ocorrência; 4. Análise dos riscos identificados nos objetivos gerais do projeto; 5 . Desenvolvimento de ações para aumentar as oportunidades e reduzir as ameaças aos objetivos do projeto; 6. Implementação de planos de respostas aos riscos, acompanhamento dos riscos identificados, monitoramento dos riscos e novos riscos e avaliação da eficácia dos processos de tratamento dos riscos.

O gerenciamento das aquisições relaciona os processos necessários para aquisição de produtos e serviços, que em estão vinculados a: 1 . Documentação das decisões de compras do projeto e identificação dos fornecedores; 2. Obtenção e seleção de fornecedores e adjudicação dos contratos; 3. Relações de aquisição, através da monitoração do desempenho do contrato e realização de mudanças e correções conforme necessário; 4. Finalização das aquisições do projeto.

O gerenciamento das partes interessadas analisa as expectativas das partes interessadas e seu impacto no projeto e desenvolver estratégias de gerenciamento apropriadas para o engajamento eficaz das partes nas decisões e execução do projeto, incluindo: 1. Identificar pessoas, grupos ou organizações que podem impactar ou serem impactados por uma decisão, atividade ou resultado do 
projeto e analisar e documentar informações relevantes relativas aos seus interesses, nível de engajamento, interdependências, influência, e seu impacto potencial no êxito do projeto; 2. Desenvolver estratégias apropriadas de gerenciamento para engajar as partes interessadas de maneira eficaz no decorrer de todo o ciclo de vida do projeto; 3. Comunicar e trabalhar com as partes interessadas para atender às suas necessidades e expectativas; 4. Monitorar os relacionamentos das partes interessadas do projeto em geral.

Existem indicações da relação entre o nível de utilização das práticas do Guia PMBOK e o relativo sucesso de um projeto. Porém a questão do sucesso do projeto versus o sucesso da gestão do projeto também deve ser considerado de forma diferenciada, pois um projeto de sucesso pode ou não ter sucesso na gestão e vice-versa. Ocorre, assim, uma mudança da visão cartesiana, onde o sucesso do projeto acontecerá se ele for executado dentro de seu escopo, custo, tempo e qualidade passando a ser: o valor agregado na entrega do projeto, a organização, a satisfação dos stakeholders e a evolução do conhecimento da organização na execução de novos projetos, demonstrando com isso o amadurecimento do gerenciamento de projetos (PMI, 2013).

\subsection{ADOÇÃO DO MODELO PMI E DO GUIA PMBOK EM PROJETOS EDUCACIONAIS}

O Project Management Institute (PMI) é a principal associação mundial de gerenciamento de projetos. Durante quase 40 anos, o PMI vem compartilhando teorias, práticas e experiências em gerenciamento, possuindo como meta principal avançar cientificamente na profissão de gerenciamento de projetos em todo o mundo, de uma maneira consciente e proativa, para que as organizações apoiem, valorizem e utilizem o gerenciamento de projetos, atribuindo seus sucessos a ele (PMI, 2013).

O PMI acredita que gerenciamento de projetos é uma competência crítica que tem uma influência positiva nos resultados das organizações e da sociedade, sendo indispensável para os resultados de qualquer empreendimento. O Programa de Pesquisa do PMI promove a ciência, a prática e a profissão de gerenciamento de projetos por meio de projetos de pesquisa, simpósios e pesquisas, divulgando 
essas informações através de publicações, conferências de pesquisa, sessões de trabalho e guias de padronização no gerenciamento de projetos, entre eles, o Project Management Body of Knowledge (PMBOK).

O Guia PMBOK em sua quinta edição reflete a colaboração e o conhecimento de gerentes de projetos na ativa e fornece os fundamentos de gerenciamento de projetos da maneira como são aplicados em uma ampla variedade de projetos. Esse padrão com reconhecimento mundial fornece aos gerentes de projetos as ferramentas essenciais para exercer o gerenciamento de projetos e entregar resultados organizacionais (PMI, 2013).

A metodologia utilizada pelo PMI e o Guia PMBOK tem sido amplamente empregada, tanto pela força de sua técnica, que consegue estruturar de maneira completa todas as fases, eventos e partes que compõem um projeto, mas principalmente pela facilidade de compreensão e acompanhamento que diferentes pessoas, de localidades diferentes, conseguem ter.

A GP surgiu como uma área específica do conhecimento, como objeto de trabalho, pesquisa e estudo na década de 1960. O que havia antes disso, para realizar um evento, era o uso das noções gerais de administração e engenharia, sem o foco em resultados diferenciados, sem início e fim bem definidos. No início, a gestão era voltada para os grandes projetos de engenharia, desenvolvimento de protótipos de sistemas e desenvolvimento de novos produtos, contudo, a partir da década de 60 surgiram alguns projetos na área educacional, voltados para o ensino e que envolviam profissionais de diferentes áreas.

A gestão de um projeto educacional é um processo complexo e dinâmico, principalmente quando aliado as TDIC, pois requer características, formatos e linguagens diferenciadas. Assim, a elaboração e manutenção de um projeto educacional com recursos digitais exige mais do que uma simples discussão do melhor modelo andragógico ou matriz curricular, exige-se um adequado gerenciamento a fim de garantir efetivamente o desenvolvimento das atividades propostas.

Como ressaltam Hermenegildo e Ribas (2008), uma gestão de projetos educacionais ideal seria responsável pela definição de objetivos e metas a serem alcançadas e estaria relacionada a tomada de decisão em todos os níveis do processo visando a ampliação do capital intelectual. Nesta perspectiva é que são 
elaborados os projetos de cursos, treinamentos, capacitações e atualizações, assim como o planejamento viável para os mesmos aspirando um crescimento socioeconômico.

O chamado capital intelectual das organizações é um valor que se constrói mediante ações educativas, muitas delas originadas em projetos que facilitam e promovem a aprendizagem. Como exemplos de projetos educacionais desenvolvidos, podem ser citados: projetos de implantação de universidades corporativas, projetos de cursos e programas de formação profissional e projetos de produção de material didático (MOURA; BARBOZA, 2013).

O futuro dos projetos educacionais voltados a formação profissional envolve a renovação permanente e progressiva dos saberes para um novo horizonte de trabalho. As tecnologias beneficiam o acesso à informação, estilos de conhecimento e compartilhamento de documentos entre indivíduos. Nesse sentido, o fluxo informacional convertido em fluxo de conhecimento, através das TDIC modifica os objetivos da ação educativa mediante uma aprendizagem cooperativa através da EAD e seu potencial interativo conferindo um novo estilo de pedagogia.

Moura e Barboza (2013) também classificam, de forma ampla, os vários tipos de projetos que ocorrem na área educacional a partir da finalidade principal ou razão de ser do projeto:

- Projetos Educacionais de Intervenção: preveem intervenção no contexto para alterar a estrutura ou dinâmica do sistema ou organização. É prevista uma mudança positiva no desempenho, como objetivo a ser atendido;

- Projetos Educacionais de Pesquisa: preveem a obtenção de conhecimentos como resultado do projeto, verificado pela experimentação;

- Projetos Educacionais de Desenvolvimento ou de Produto: têm como finalidade a implantação de novas atividades, serviços ou produtos;

- Projetos Educacionais de Ensino: são elaborados dentro de uma disciplina, dirigidos à melhoria do processo de ensino-aprendizagem;

- Projetos Educacionais de Trabalho: são desenvolvidos por alunos em uma disciplina, sob a orientação de um professor, para a aprendizagem de conceitos e desenvolvimento de competências específicas. 
Apesar de serem diferentes, podem existir situações nas quais um mesmo projeto se enquadre em mais de um tipo. Pode-se observar que os cinco tipos de projetos assinalados não são excludentes, significando que podem existir situações em que os mesmos ocorrem de forma articulada ou integrada.

A atividade predominante do projeto educacional e sua finalidade principal são os critérios usados para classificar o tipo de projeto. Assim, um projeto de desenvolvimento ou de produto pode incluir atividades que representam algum tipo de intervenção, ou seja, um determinado tipo de projeto pode abranger atividades que seriam as atividades básicas de outro tipo de projeto.

Neste sentido, utilizar mecanismos capazes de propiciar o planejamento, organização, capacitação da direção e de controle das atividades desenvolvidas, segundo Moura e Barboza (2013), é elemento basilar para que os objetivos sejam atingidos. Desenvolver programas e projetos educacionais contemplando o resultado do planejamento elaborado constitui-se de atividade elementar, embora desenvolvida por muitas organizações com deficiências, principalmente com relação ao desdobramento dos objetivos do planejamento em questão.

Planejar um projeto educacional no contexto da gestão do conhecimento como fator gerador de vantagem competitiva deve considerar aspectos relevantes para contextualização de um planejamento alinhado a GP. Um planejamento ideal deve estar integrado com os aspectos relevantes ao objetivo delineado e também as dificuldades de execução, de modo que para fins de operacionalidade, os aspectos metodológicos, tecnológicos, organizacionais e educacionais estejam presentes (BASSIS, 2009).

O que se observa é que a gestão de um projeto educacional pode ser composta por múltiplos subprojetos, tendo cada qual sua tipologia distinta compondo um só projeto. Dessa característica de complexidade visualiza-se: a heterogeneidade de perfis profissionais, tecnologias agregadas, métodos e técnicas de planejamento e gestão. A coerência harmônica dos prazos, recursos tecnológicos e a comunicação são grandes desafios, porém não são maiores do que a capacidade dos profissionais envolvidos no planejamento do projeto em visualizar as dimensões envolvidas e de forma dinâmica do casamento entre educação, tecnologia e gestão em um projeto através da EAD. 
A ideia da gestão de projetos educacionais é fazer o planejamento do projeto de uma forma que a equipe participe da construção do inicio do processo, representando apenas o essencial, podendo ser usado primeiro como documento único e consistente do planejamento do projeto, imediatamente seguido pela execução; e em segundo como ferramenta preliminar que conformará a lógica do projeto, servindo como base para a transcrição posterior a um plano de projeto representado de modo formal (FINOCCHIO JUNIOR, 2013).

Um projeto educacional demanda para sua efetiva realização o que Bassis (2009) denomina de Sistema Educacional, que é o conjunto formado por pessoas, processos, sistemas de informação, conteúdos, materiais, modelo de gestão, métodos e meios. A proposta de desenvolver um projeto educacional presencial, a distância ou híbrido, baseado no modelo do PMI e do Guia PMBOK representa uma forma importante de prezar por todos os elementos fundamentais na formação acadêmica adequada do ser humano, visto que a adoção deste método significa contribuir para uma melhor adaptação de uma educação centrada interação com a realidade.

\subsubsection{Conceitos do modelo PMBOK aplicados aos projetos de educação a distância}

Por se tratar de uma modalidade de ensino em amplo crescimento no Brasil, os projetos de EAD carecem da adoção de um modelo de gestão que considere um enfoque sistêmico na produção de cursos, envolvendo uma equipe multidisciplinar, com habilidades e conhecimentos especializados, interligando processos vinculados à concepção, produção e implementação de programas e incluindo desde a escolha do modelo conceitual de ensino/aprendizagem até procedimentos gerenciais que garantam a realização do projeto (ARNOLD, 2002). É nesse contexto que a GP no modelo do PMBOK vem ganhando espaço.

Além desse potencial reconhecido, outros fatores vêm contribuindo para que projetos de EAD se estabeleçam de vez como uma estratégia de ensino/aprendizagem, dentre os quais: a) a percepção, por parte do governo federal, de que a educação a distância pode ser uma alternativa para a ampla demanda social por democratização do ensino, preceito estampado na LDBE - Lei 
de Diretrizes e Bases da Educação - Lei 9394 (BRASIL, 1996); b) a necessidade das organizações de capacitarem seus profissionais de forma contínua com vistas à otimização de processos e ganhos de produtividade; e, c) a demanda crescente do mercado de trabalho por profissionais cada vez mais qualificados, com domínios específicos em diferentes áreas do conhecimento (CASTRO; LADEIRA, 2010).

No universo das organizações, inclusive as educacionais, o termo "boas práticas" é representado por um conjunto de técnicas identificadas como as melhores para atingir um determinado objetivo, tarefa ou ação. É sempre recomendável seguir as "boas práticas" estruturando os projetos baseados em guias e manuais em prol de gerenciar as circunstâncias em que o conhecimento pode prosperar (BESSA, 2009).

O PMBOK é um guia de boas práticas reconhecido na área de GP que descreve normas, métodos, processos e práticas estabelecidas para gerenciar projetos de qualquer natureza com alvo na aplicação de ferramentas e técnicas para aumentar as chances de sucesso de um projeto incorporando processos e atividades que suprem as necessidades de todas as etapas ou fases do ciclo de vida de um projeto. Dessa forma é plausível e beneplácito a adoção do PMBOK devido a sua característica genérica e aplicada a todos os tipos de projetos, inclusive projetos educacionais (ANDRADE; TAIT, 2012).

A vantagem da utilização do Guia PMBOK como fonte de inspiração é que a experiência e o discernimento da equipe de gerenciamento do projeto poderão determinar para cada situação e contexto específico, aquilo que deve ou não ser utilizado do Guia. As boas práticas são caracterizadas justamente pelo o seu uso de acordo com a demanda das especificidades de cada projeto, pois cada uma das 10 áreas de conhecimento do PMBOK tem seus processos e a equipe, pode utilizar-se apenas dos processos que vê necessidade.

Analisando a efetividade da GP, Pinheiro e Rocha (2012), alertam que as instituições que tiveram por base o emprego da metodologia de gerenciamento de projetos baseados no PMI e no Guia PMBOK, proporcionam melhoria dos resultados de gestão, pois ampliaram a eficiência do processo, contribuindo para a melhoria da eficácia, traduzida pelo melhor atingimento das metas de gestão. A fronteira entre o sucesso e o fracasso é tênue e se dá por questões intangíveis, 
portanto, lograr êxito com a adoção de novos recursos de gestão requer o enfrentamento de fatores paradigmáticos, comuns às organizações.

Para que projetos de educação a distância operem de maneira eficiente e eficaz é necessário um grau estimável de requinte gerencial. Almeida et al (2006) alegam que os projetos de EAD possuem especificidades que precisam de um acompanhamento mais detalhado e sistemático e que ao planejar e desenvolver um projeto nesta modalidade se faz necessário atender uma série de fatores relativos à viabilização, organização e funcionamento do curso. Nesse conjunto, a GP baseado no modelo PMBOK se apresenta como uma viável ferramenta para atender esta demanda, uma vez que possui uma metodologia capaz de nortear esse processo.

Para Ribeiro, Timm e Zaro (2007) planejar e executar projetos de EAD requer um planejamento estratégico detalhado, que se desdobra em inúmeras tarefas, com suas particularidades que são efetuadas por equipes multidisciplinares. A carência de um plano de gestão é um fator crítico, pois em um sistema de EAD é preciso compreender como os projetos são conduzidos, integrados e produzidos para possibilitar que 0 curso atenda tanto as necessidades do aprendiz como as da instituição promotora do projeto (LENZI, 2010).

O processo de planejamento de cursos a distância é muito mais do que traduzir aulas presenciais para um ambiente web. O desenvolvimento de um ambiente para suporte ao processo ensino/aprendizagem apoiado pelas TDIC pressupõe um cuidadoso planejamento. A estrutura do modelo pode ser dividida nas etapas de definição do contexto do ambiente, das estratégias pedagógicas, das táticas pedagógicas, da estrutura de recursos do ambiente e implementação do design educativo (FRANCIOSI et al.,2001).

As TDIC forneceram inúmeros recursos ambientais para aplicação em EAD para autoria e gerenciamento de cursos a distância na internet, como, por exemplo, o Moodle (MOODLE, 2015), o TelEduc (SILVA; FREIRE; ROCHA, 2013), e o Lotus Learning Space (LOTUS, 2016), entre muitos outros sistemas de gestão da EAD. Inclusive há uma forte tendência em personalizar ambientes com programa de códigos-fonte abertos, gerando Ambientes Virtuais de Aprendizagem (AVA) próprios. 
O advento do uso das tecnologias e ambientes virtuais na educação, demanda a necessidade de uma redefinação do conceito de gestão em EAD, ou seja, um gerenciamento contemporâneo capaz de assegurar criatividade, inovação, definição de estratégias e muita interação, condição essencial para qualidade do trabalho andragógico dos cursos a distância (POLAK; 2009).

Bernardi, Daudt e Behar (2013) ressaltam que a gestão, analisada por essa perspectiva, demanda uma nova dinâmica no conceito de EAD, apropriando-se da flexibilidade e organização exigidas por essa modalidade, combinada com os aspectos de design pedagógico, planejamento e estratégias de comunicação. A mobilização e implementação desses aspectos podem garantir a mediação dos diferentes atores envolvidos no processo dentre seus espaços no oferecimento de um ensino de excelência nos cursos dessa modalidade, quando associada a modelos de gestão de projetos como PMBOK.

Como razão do projeto de EAD é a educação em seus processos de ensino-aprendizagem, a ênfase das questões a serem observadas no planejamento está diretamente ligada na relação organização-docente-discente. Realizar um curso de formação profissional através da EAD baseado no Guia PMBOK é, primordialmente, uma revisão da forma de gerenciar cada vez mais estrategicamente e menos operacionalmente.

\subsubsection{Gestão de projetos educacionais a distância: capacitação de profissionais para o uso de TDIC como recursos pedagógicos na educação.}

A EAD no Brasil passa por um período de consolidação e a maior evidência desse fato é o projeto da Universidade Virtual do Estado de São Paulo, que reúne parcerias da USP, Unicamp e Unesp, além da FAPESP e TV Cultura. Moran (2007) comenta que essa evolução pode ser derivada do fato de que, nos primeiros anos, o foco da modalidade foi a capacitação dos professores em serviço, porém sem aplicação de projetos gerenciais peculiares baseados em processos (MORAN, 2007).

Segundo Martins et al (2013), crescente disponibilidade de cursos a distância para formação de professores, seja inicial (licenciaturas) ou continuada (cursos de especialização e aperfeiçoamento) desperta questionamentos quanto ao tipo de relação que pode haver entre a oferta, as características pessoais dos 
aprendizes, o desempenho e o uso competente dos recursos tecnológicos necessários às atividades de estudo e o processo de gerenciamento, visto que tais elementos concorrem para a qualidade da formação ofertada.

A partir do advento da atual sociedade da informação, fomentada pelo desenvolvimento e democratização das tecnologias de informação, que ocorre de forma massiva nos últimos anos, não se pode pensar em manter o modelo tradicional da educação, sob a pena de cair no anacronismo frente às novas tecnologias (ALVES; PEREIRA; PEREIRA, 2015).

Portanto, é de se esperar que a atualização de professores oferecida em cursos a distância permita ao aprendiz uma imersão na cultura digital, reestruturando seu pensamento em novos modos de expressá-lo, de interação, construção, trabalho colaborativo e reorganização do seu próprio tempo, desenvolvendo práticas não somente no nível cognitivo, mas também no nível da gestão. Ao lado disso, considera-se que para participar de forma competente dos cursos a distância e ter bom desempenho de aprendizagem é necessário reunir um conjunto de características pessoais e ter domínio das TDIC utilizadas para a mediação andragógica do ensino tal como preconizam Moore e Kearsley (2007).

Diante do exposto, a demanda de cursos de capacitação de profissionais para o uso de tecnologias como recursos educacionais através da EAD gerenciado por projetos é cogente. Segundo o Guia PMBOK a aplicação dos conhecimentos de gerenciamento de projetos requer o gerenciamento eficaz dos processos de gerenciamento de projetos, considerando que "um processo é um conjunto de ações e atividades inter-relacionadas que são executadas para criar um produto, serviço ou resultado pré-especificado" (PMI, 2013).

A problemática central da gestão de projetos educacionais está relacionada à dificuldade de preparar, de forma científica, um plano de trabalho que realmente atenda as necessidades de todos os sujeitos envolvidos. Pela característica plural e pela heterogeneidade de seus aprendizes, professores ou dirigentes, a implementação e manutenção de um curso de atualização docente requer cuidados adicionais, haja vista ser a gestão educacional, um campo de extrema importância para se compreender o conjunto do processo de ensinoaprendizagem (RIBEIRO; TIMM; ZARO, 2007). 
Deste modo, é perceptível que a gestão de projetos educacionais baseia-se nas ideias e processos da administração geral, mas guarda certas particularidades que merecem cuidados especiais dos gestores. Por ser um projeto de natureza peculiar, as formas de planejar, organizar, dirigir e controlar precisam ser diferenciadas das decisões do gestor e o processo de ensinoaprendizagem deve contemplar além das questões andragógicas, as administrativas e tecnológicas, especialmente quando se tratar de uma proposta de qualificação docente.

Um dos primeiros desafios gerenciais é estruturar os recursos para iniciar a oferta de cursos de qualificação docente, uma vez que, geralmente, as universidades não estão focadas em cursos desta perspectiva. O ideal é que estes projetos estejam bem concebidos e enraizados em todos os departamentos e centros de ensino da instituição. O desafio está na mudança de mentalidade de toda a comunidade universitária em prol de uma gênese docente efetiva, o que exige um trabalho descentralizado e participativo com discussões entre os sujeitos em seus respectivos setores institucionais (CASTRO; LADEIRA, 2010).

A consolidação de um projeto de curso de atualização docente a distância para a prática do ser docente induz uma (res)significação de paradigmas educacionais, sobretudo no que diz respeito à concepção de ensino e de aprendizagem, à compreensão de educação como um sistema aberto, à construção do conhecimento em rede e como processo, ao redimensionamento dos tempos/espaços educacionais como construção subjetiva, à comunicação e à autonomia dos sujeitos da ação educativa. Nesta condição, a opção por um modelo de GP baseado no Guia PMBOK torna-se um desafio e ao mesmo tempo uma opção confiável aos idealizadores do projeto.

Do ponto de vista organizacional, a capacitação de profissionais para o uso de TDIC como recursos pedagógicos na educação através da EAD nas universidades implica no alinhamento de estratégias gerenciais e educacionais. A consequência é a necessidade de adoção de um estilo de gestão que considere a necessidade de gerir equipes que trabalhem com alto grau de interfuncionalidade e com uma intensa dinâmica de interação entre seus membros. Tais considerações refletem as características predominantes do trabalho desenvolvido em projetos educacionais, em projetos de EAD e na proposta do PMI. 
A gestão de um projeto de capacitação profissional pode contemplar processos diversos, responsável por uma linha de ação, entendida como planejamento. $O$ processo de iniciação envolve os diagnósticos e análises preliminares, possuindo como objetivos principais delinear o perfil do público-alvo, suas necessidades de atualização, suas expectativas e identificar o contexto sócio-empresarial, geográfico e tecnológico deste público (LEE; OWENS, 2000). As informações referentes a essa etapa nortearão o projeto assim como a produção e a implementação do mesmo.

O processo subsequente é de planejamento do projeto. Tal formulação se faz a partir dos objetivos educacionais, a projeção da matriz curricular, os conteúdos e os programas do curso, especificação de materiais, recursos educacionais, sistemas de apoio ao desempenho do aluno e as avaliações (ARNOLD, 2002).

De modo semelhante, Franciosi et al (2001) propõem a construção de um projeto de um curso em EAD a partir de duas etapas, sendo a primeira, o design educativo que consiste na modelagem da arquitetura pedagógica do ambiente por meio do plano de ensino das disciplinas e de pressupostos pedagógicos e, a segunda, o design computacional que consiste na organização das atividades e recursos necessários à implementação do conteúdo que propicie autonomia e reflexão crítica do aluno.

O processo de execução do curso é a otimização do planejamento, envolvendo atividades que vão desde o estabelecimento de um cronograma de efetivação como a elaboração de mídias até a avaliação e aprovação do material didático. Nessa fase faz-se mister o levantamento dos recursos necessários para a implementação das atividades interativas e colaborativas com a delimitação de atividades síncronas e assíncronas, elaboração e organização dos recursos, como também a definição de ferramentas de colaboração, informação, acompanhamento e de comunicação que serão utilizadas (ARNOLD, 2002; FRANCIOSI et al., 2001).

Santos (2002) sugere que exista nesse processo a preocupação com o treinamento de professores, tutores e monitores, formação de convênios e parcerias, definição de metodologia e critérios de avaliação. E Arnold (2002) sugere que a execução demanda uma logística própria, incluindo procedimentos 
didáticos, tecnológicos e administrativos que devem ser monitorados constantemente.

No processo de encerramento do programa Castro e Ladeira (2010) sugere avaliar a aplicabilidade das atividades propostas, o tempo de retorno das respostas às questões acadêmicas e administrativas, a estrutura da equipe de suporte e da equipe administrativa, a satisfação do aluno quanto à equipe de $E A D$, isto é, professores e tutores e a relação e finalmente a relação custobenefício do programa.

Quando se compara a realização dos processos de capacitação profissional ou projetos de cursos na modalidade a distância, segundo alguns autores da área educacional, verifica-se que os cinco processos de gerenciamento, reflexões sobre a realidade e necessidades, supõe todas as fases disseminadas pelo PMI para geração de um produto ou serviço.

O estabelecimento de uma cultura de projetos na área de educação deve superar algumas dificuldades específicas que não ocorrem em projetos de outras áreas, haja vista poderem ser tangíveis e avaliados com facilidade. Entretanto um projeto de capacitação de profissionais para o uso de TDIC como recursos pedagógicos na educação, que possui como objetivo a aquisição de habilidades e competências, dificilmente pode ser medido diretamente e pode não ser imediatamente visível assim que o projeto termina. Portanto, planejar e gerenciar um projeto educacional são práticas que apresentam um amplo estudo científico. 
Plano

cognitiva conitoramento ogprática

을. 을.

产 Conhecimento

açõeso

ב. Avaliação distância

co grupos oprocesso

projeto $\varlimsup^{\text {Avaliar }}$

contidas

言 흥항.

áreas
baseando-se $\overline{\overline{\mathbf{D}}}$ "reflexiva

OBJETIVO

gerenciamento

OBJETIVOS 


\section{OBJETIVOS}

\subsection{OBJETIVO GERAL}

Desenvolver um projeto educacional a distância utilizando ferramentas de gestão presentes no Guia PMBOK.

\subsection{OBJETIVOS ESPECÍFICOS}

- Avaliar a viabilidade do projeto educacional baseando-se na efetividade das ações contidas no Plano de Monitoramento e Avaliação. 


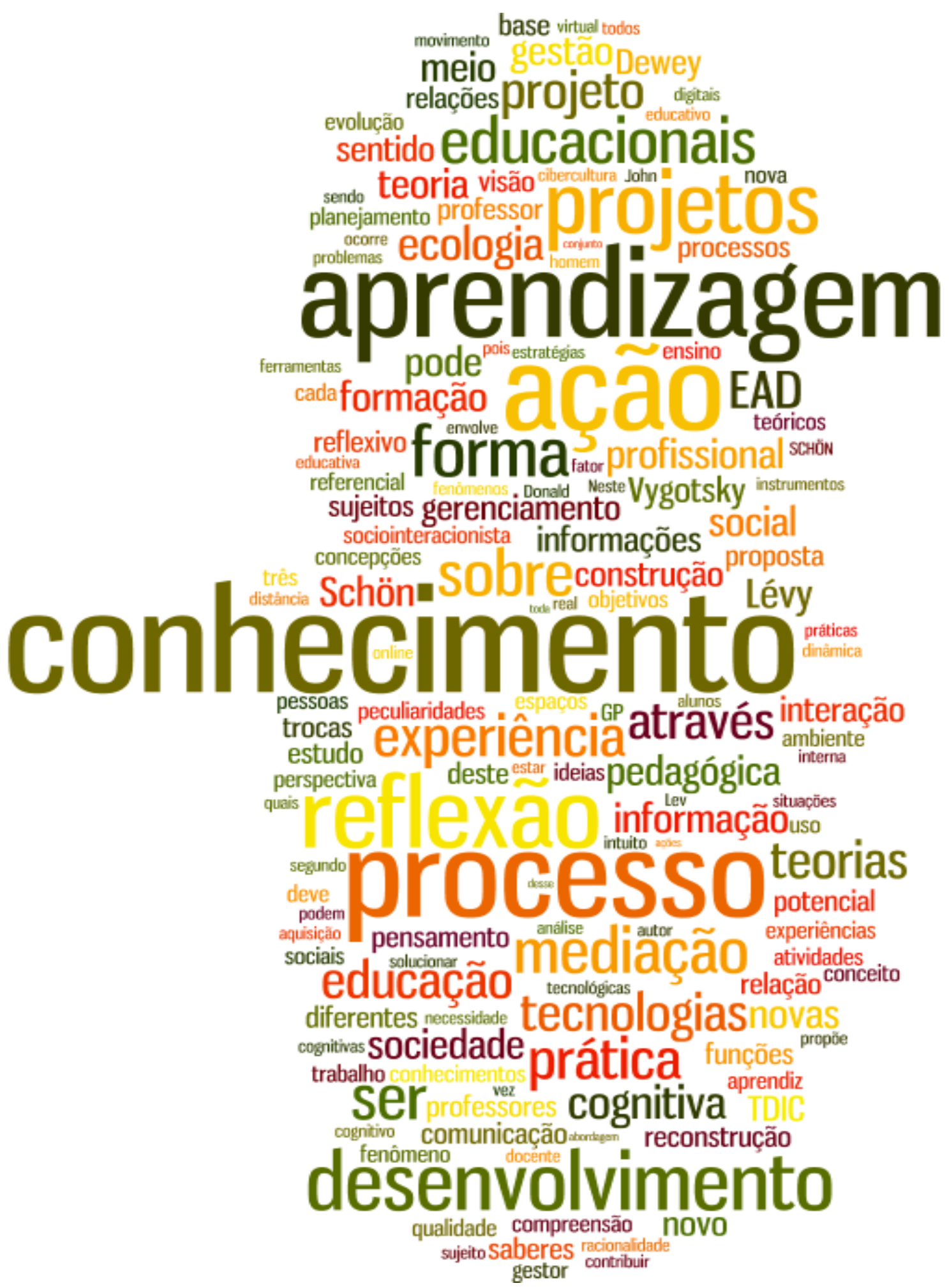

REFERENCIAL METODOLÓGICO-CONCEITUAL 


\section{REFERENCIAL METODOLÓGICO-CONCEITUAL}

\subsection{CONCEPÇÕES SOBRE AS TEORIAS DE LEV VYGOTSKY, PIERRE LÉVY, JOHN DEWEY E DONALD SCHÖN}

Identificar um referencial teórico para atingir o objetivo deste estudo proporcionou o conhecimento de diferentes concepções e teorias que fundamentam o processo de GP, a inserção de TDIC e a incorporação da educação a distância para as práticas pedagógicas na educação. Para atender a tais exigências que a gestão de projetos educacionais propõe, é necessário investir no planejamento e na organização dos suportes de aprendizagem e dos espaços de socialização do conhecimento entre os agentes do processo.

A figura do gestor na educação online está representada pelo especialista que planeja o curso, produz e garante a qualidade do material didático que será utilizado, e pelo tutor que de maneira síncrona ou assíncrona, deve garantir a eficácia comunicacional para efetivação do referido material, conduzindo, acompanhando e avaliando a aprendizagem dos alunos (MERCADO; FIGUEIREDO; JOBIM, 2009).

Neste formato, salienta-se a proposta de aprendizagem por projetos. Esta perspectiva pedagógica encontra referenciais teóricos em diferentes autores como por exemplo nas ideias de Lev Semenovitch Vygotsky (1856 - 1934), bem como em outros pensadores, dentre os quais se destacam John Dewey (1859 - 1952), Donald Alan Schön (1930 -1997) e Pierre Lévy (1956).

As TDIC deram um novo sentido a EAD por meio de interfaces de aprendizagem estruturadas para facilitar os contatos e a construção do conhecimento entre os participantes nos ambientes virtuais de aprendizagem como uma proposta pedagógica, rica em trocas sociais. Neste contexto, o planejamento e a gestão de um ambiente virtual de aprendizagem para capacitação docente por meio de um curso a distância foi construído na perspectiva das teorias sóciointeracionista e da ecologia cognitiva associada ao conceito do ensino reflexivo.

O primeiro referencial partiu de Lev Semionóvich Vygotsky (1896 1934), que postulou a teoria sóciointeracionista, a qual concebe que o homem constitui-se através de sua interação com o meio em que está inserido, 
fortalecendo o sentido de estabelecer relevância ao meio social como fator precursor da prática de mediação pedagógica online e do desenvolvimento cognitivo do aprendiz.

No cenário da EAD, em que pessoas situadas em espaços e tempos diferenciados buscam interagir com o intuito construir sua aprendizagem em AVA, a teoria sociointeracionista de Vygotsky atende às peculiaridades dessa nova abordagem de ensino/aprendizagem, em razão de enfatizar a interação social como fator que propicia trocas recíprocas que, na concepção de educadores, é um fator importante para o desenvolvimento cognitivo do aprendiz (BARBOSA, 2012).

Já com relação às questões de gerenciamento, as ideias de Vygostky desencadeiam potenciais relativos ao compartilhamento de informações, conhecimentos, funções e papéis. Trata-se de um processo que caminha do plano social, relações interpessoais, para o plano individual interno, relações intrapessoais, ou seja, a reconstrução interna de uma operação externa.

Vygostky distinguia dois níveis de desenvolvimento: o real e o potencial. $\mathrm{O}$ nível de desenvolvimento real define as funções que já amadureceram, e o nível de desenvolvimento potencial, define as funções que possuem as bases necessárias para serem desenvolvidas. Este processo define, o que ele chama de "Zona de desenvolvimento Proximal (ZDP)", ou seja, a distância entre o real, que se costuma determinar através da solução independente de problemas, e o potencial, determinado através da solução de problemas sob orientação de especialistas mais capazes.

Podemos considerar como "gestor vygotskyano", aquele que possuindo mais experiência em gerenciamento, faria o planejamento do projeto através da mediação do conhecimento, vinculando seu trabalho em criar Zonas de Desenvolvimento Proximal, ou seja, atuando através de ações de intervenção, interagindo e mediando o processo, apoiando os stakeholders de forma que eles utilizem o conhecimento que eles já possuem paralelamente ao novo que esta sendo apresentado de forma a alcançar os objetivos programados como também superá-los, alcançando avanços que não aconteceriam de forma espontânea. É nessa direção que a teoria de Vygotsky tem muito a contribuir na gestão de projetos educacionais. 
$\mathrm{Na}$ visão vygotskyniana, o ambiente social e histórico estabelecido nas relações é o ponto central. Ainda acredita que o conhecimento se constrói com participação e colaboração do outro, isto é, no social, tendo como meios de intercâmbio e estímulo à aquisição deste conhecimento, a ênfase na discussão em grupo e no poder de argumentação. A relação sujeito e sociedade é inexoravelmente indissociável, bem como, está diretamente relacionada ao processo de trabalho e sua interação (THOFEHRN, LEOPARDI, 2006).

Segundo Andrade e Vicari (2011) a interação está na verdade inserida dentro do processo de mediação que ocorre por meio de instrumentos e signos. Onde estarão estes signos e instrumentos nos ambientes de EAD? Ambos podem estar modelados nas ferramentas de chat, na linguagem adotada para a comunicação, nos serviços de e-mail, de fórum, na vídeo e teleconferência, em toda e qualquer ferramenta que exerça a função de mediação.

Lev Vygotsky propunha romper com a forma tradicional de análise dos fenômenos, ou seja, fragmentados, pois acreditava que o estudo de forma conjunta dos fenômenos possibilitava, ao investigador, compreender o caráter dinâmico do funcionamento mental, além de possibilitar a observação da interação desse fenômeno no processo de desenvolvimento do ser humano. A ideia de realização de um projeto engloba ação e reflexão entre pessoas ou de uma pessoa com as ideias de outrem, uma vez que o pensamento humano encontrase imbricado com o seu ambiente social e ocorre na zona proximal de desenvolvimento constituída no contexto de atuação das pessoas (THOFEHRN, LEOPARDI, 2006).

Assim, o sociointeracionismo dá um novo significado ao processo de EAD pela diversidade de mediação das TDIC. Na era da informação e em tempos de comunicação digital, o ato de aprender adquire novas concepções e linguagens e novas formas de explorar o saber permitem criar oportunidades para que todos possam estar incluídos e interagindo na sociedade da informação, habilitados ou habilitando-se a lidar com as tecnologias digitais de forma participativa. A aplicação das teorias sociointeracionista e da ecologia cognitiva ao processo de mediação da educação online permite compreender as peculiaridades da dinâmica interativa que as ferramentas tecnológicas proporcionam aos sujeitos da ação educativa (BARBOSA, 2012). 
Com a necessidade de explicar as peculiaridades da aprendizagem nos espaços virtuais, o segundo referencial utilizado foi o de Pierre Lévy. Este autor apresenta a teoria da ecologia cognitiva no intuito de levar a adequada compreensão das potencialidades e possibilidades de aprendizagem integrada pelas tecnologias intelectuais. Considerando que ecologia refere-se às relações, interações e diálogos entre organismos e cognitiva, a relação com um novo conhecimento, a teoria propõe o estudo de uma nova dinâmica na relação entre homem, tecnologia e ambiente de aprendizagem, visando o estabelecimento e a compreensão de outras formas de aprendizagem e construção do conhecimento (ANJOS, ANDRADE, 2008).

Em linhas gerais, a ecologia cognitiva diz respeito, segundo Lévy (2001), ao estudo das dimensões técnicas e coletivas da cognição partindo da infraestrutura tecnológica, mas não permanecendo somente nela. Isto significa partir das esferas da mente e da apreensão, o que envolve os degraus da aprendizagem e os fundamentos da educação na cibercultura, integrando tecnologias e perspectivas de transformação conjuntural de uma sociedade de interação entre os indivíduos e o desenvolvimento das conjecturas estruturais da evolução social.

Nesta perspectiva, a cibercultura se tornou no século XX um fenômeno cada vez mais presente no processo gerencial e educativo. A cibercultura representa uma ferramenta imprescindível porque viabiliza a ampliação e melhoramento dos conhecimentos dos sujeitos envolvidos, na medida em que todos os envolvidos manipulam as ferramentas tecnológicas de forma contínua, estabelece outra via para aperfeiçoar-se.

As interfaces digitais, segundo Lévy (2001), favorecem o domínio de novas informações e experiências humanas, as quais devem ser somadas às já existentes. Nesse processo de construção de novos saberes, o papel do professor, na função de mediador e gestor do conhecimento, é investir nas potencialidades educacionais que as TDIC oferecem à construção do conhecimento compartilhado entre os aprendizes, valorizando as trocas de informações para o alcance dos objetivos de aprendizagem, permitindo desenvolver contatos e atividades por meio do diálogo participativo que possibilitem o "estar junto virtual". 
Frente à flexibilidade da veiculação de informações e da aplicabilidade das tecnologias de informática, a evolução do conhecimento exige do sujeito uma constante reformulação de sua formação profissional, porque diversas áreas do conhecimento acompanham a evolução dos saberes. Os processos educativos encontram-se hoje submetidos a novas restrições no que diz respeito à quantidade, diversidade e velocidade de evolução dos saberes (LÉVY, 2001).

Partindo desse princípio, Lévy (2010) propõe que toda instituição é uma tecnologia intelectual, e os processos são atividades cognitivas, com base no pressuposto de que os sujeitos não apenas transmitem ou reproduzem as estruturas de sua cultura, eles também as reinterpretam de acordo com seus interesses e projetos.

Grande parte dos projetos educacionais apenas reorganiza a visão de mundo de seus usuários e seus reflexos mentais. $\mathrm{Na}$ medida em que repensarmos a GP através da inserção de teorias de aprendizagem e das concepções tecnológicas, certas funções são eliminadas, novas habilidades aparecem e a ecologia cognitiva se transforma. $O$ que equivale a dizer que a inteligência coletiva estaria combinada com a habilidade de organizar comportamentos, revelar significados, arquitetar projetos e conservá-los, solucionar dificuldades e analisá-las.

O terceiro referencial empregado foi o da "Epistemologia da Prática Reflexiva" ou corrente do "Professor Reflexivo". Esta perspectiva para a formação de professores emergiu de um movimento mundial de reformas educacionais nos finais da década de 1980 e início da década de 1990. Esta teoria foi proposta por estudiosos que discutiam a formação inicial e continuada de professores em diversos países, tais como Schön (1983; 1987 e 2000) e Zeichner (1993) nos Estados Unidos, Pérez Gómez (1990 e 1992) e Marcelo García (1992 e 1999) na Espanha, Nóvoa (1992) e Alarcão (1996) em Portugal.

Entender a ideia de ensino reflexivo implica procurar as suas raízes no pensamento sobre a educação. Importa, então, caracterizar o pensamento reflexivo de John Dewey (1959) que relata a educação como uma reconstrução ou reorganização da experiência adicionada ao significado da experiência, e que amplia a capacidade de conduzir o destino da experiência subsequente. 
Para John Dewey, o conhecimento produz-se mediante a reconstrução da experiência. Durante o processo de experiência humana cada um aprende ao mobilizar o conjunto dos aprendizados anteriores em uma situação que, por ser nova, acrescenta alguma coisa à experiência anterior. Isso desloca a relação de ensino da ênfase exclusiva no relato lógico que supõe na matéria o eixo da atividade: ensinam-se alunos e não matérias. Da lógica interna dos mecanismos de transmissão e aquisição de conhecimento, centra-se a atividade pedagógica na dinâmica interna do que se passa a caracterizar como reconstrução da experiência (BOTO, 2006).

Sob esta visão Deweyana, em que em que o mundo está em constante movimento sob o impulso do modo de vida democrático, o conhecimento científico deve ser apresentado, sempre, como provisório. Neste prisma, tanto o empenho dos cientistas para dominar os fenômenos naturais, individuais e sociais, quanto à transposição dos saberes daí resultantes para terrenos alheios ao de sua elaboração, subjugam-se a definições que dependem da coletividade, esta também em permanente movimento (DA CUNHA, 2001).

Para este autor, a educação não pode ficar reduzida à racionalidade técnica, pois não dará conta de solucionar os problemas que delas emergem. É nesse sentido que a ação reflexiva, proposta por Dewey, aplicada na formação inicial e continuada de professores, apresenta-se como uma possibilidade de ruptura deste modelo, sendo o ponto de partida na direção de uma racionalidade prática. A necessidade de formar professores que venham a refletir sobre a sua prática, na expectativa de que a reflexão será um desenvolvimento do pensamento e da ação (SOUZA, MARTINELI, 2009).

Sob os ideários de Dewey vieram à luz as primeiras discussões referentes à necessidade de proporcionar, por meio da educação, as condições para que um estudante se tornasse protagonista do seu processo de aprendizagem, ao se reportar especificamente aos projetos como uma abordagem pedagógica. Mais do que o olhar sobre aspectos estruturais dos projetos educacionais, deve-se adquirir uma compreensão sobre os valores presentes no seu desenvolvimento e os aspectos construtivos de um fazer educativo capaz de contribuir para a autonomia dos sujeitos em processo de formação (ALENCASTRO, 2010). 
Uma das contribuições que se constitui em uma referência aos estudos, foi a proposta de Donald Schön para programas de desenvolvimento de professores com a utilização de momentos estruturados da prática pedagógica, com base em três ideias centrais: o conhecimento na ação, a reflexão na ação e a reflexão sobre a reflexão na ação.

Esses três processos que se complementam em intervenção racional, compõem o pensamento prático do professor, com os quais ele enfrenta as diferentes situações no cotidiano educativo. Refletindo na e sobre a ação, o professor torna-se um investigador, afastando-se da racionalidade técnica e de regras derivadas de teorias externas, de prescrições curriculares, conhecendo mais profundamente as peculiaridades de seu trabalho e elaborando estratégias de ação mais adequadas (SCHÖN, 2000).

Ressalta-se que as práticas de ensino exigem um professor com qualidades e perspectivas profissionais diferentes, mais exigentes e atentos aos conceitos contemporâneos do ato de educar e da nova sociedade da informação. O professor mediador e articulador, contudo, sempre será a pessoa que criará possibilidades de construção do conhecimento, em parceria com seus alunos, dentro dos ambientes de aprendizagem e de acordo com as estratégias educacionais eleitas naquele momento (FRANÇA, 2007).

Schön afirmava que com base nos conhecimentos teóricos e na experiência prática é possível solucionar um problema passando pelas fases de caracterização da situação problemática, desenvolvimento da sugestão, observação, experimentação, reelaboração intelectual e verificação dos resultados.

Estes conhecimentos podem ser demonstrados pelos profissionais quando executam uma ação, mas há três tipos distintos de reflexão: (1) reflexão na ação que seria o pensar no decurso da ação sem interrompê-la, provocando reformulação do que está sendo feito, pois o profissional vivencia situações que extrapolam suas experiências prévias, tendo, entretanto, o conhecimento como base para a ação; (2) reflexão sobre a ação que consiste na reconstrução mental da ação, analisando-a retrospectivamente e incorporando-a ao seu repertório de experiências adquiridas; e, (3) reflexão sobre a reflexão na ação que equivale ao 
processo que leva o profissional a progredir no seu desenvolvimento e construir sua forma pessoal de conhecer (FILHO, 2010).

A aderência do conceito de profissional reflexivo para a área de gerenciamento de projetos pode ser traduzida através da análise diária que um gerente de projetos vivencia em com os três níveis de reflexão apresentados por Schön: reflexão na ação (praticamente automática), reflexão sobre a ação (quando pensa no que deu certo, no que deu errado, nas reações e motivação da equipe, etc) e a reflexão sobre a reflexão na ação, ou seja, quando estabelece o seu "lessons learned" (lições aprendidas) dos projetos (FILHO, 2010).

Um projeto pode ser caracterizado como um processo de reflexão prática entre a ação e a cognição em que parte das experiências e cultura de soluções de projeto adquirido com a prática e com a compreensão de outros projetos se materializa pela reinterpretação e reutilização de soluções conhecidas, como fonte do processo criativo de projeto (SCHÖN, 1983).

Donald Schön defende que o profissional competente deve improvisar, inventando e testando estratégias situacionais que ele próprio produz, assim, 0 gerente de projetos além de conhecer as boas práticas contidas no Guia PMBOK do PMI, englobando a gestão de tempo, custos, prazos, pessoas, qualidade, aquisições e riscos, deve assumir sua posição de profissional reflexivo, pesquisador e crítico.

Ao trazer à discussão, neste estudo, a visão de teóricos como Lev Vygotsky, e Pierre Lévy, John Dewey e Donald Schön pode garantir um arcabouço teórico que possibilite pensar num modelo educacional mais coerente com os reclamos da sociedade contemporânea, uma vez que compartilham elementos que podem contribuir diretamente para a gestão e construção dessas novas metodologias em EAD.

Com base nos autores investigados, visualiza-se que a sociedade caminha para o estabelecimento da popularidade das tecnologias digitais de informação e comunicação em seu cotidiano. O que pode ser visto é a confirmação das teorias destes estudiosos, inclusive sociólogos, que já vislumbravam estas características sociais há décadas, não como modismo, mas sim como um fenômeno de características positivas e negativas. 


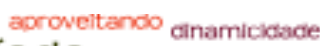

período açōes

gerente

atividades aplicação

profissionais adotados

aprendizagem

durantecomunicação utilizados

durantecomunica rerlexva Escola gerenciamento centro objetos rearzadas Conteúdos técnicos pesaúsado especialzacso tratamento anclise conteuodo gula observaçoes professores

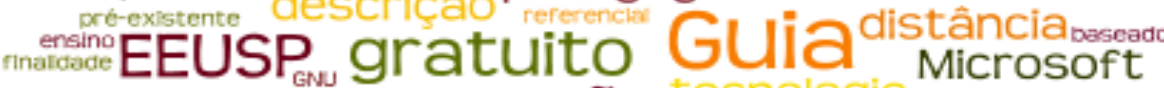
relação capacitação bem docentes apresentou

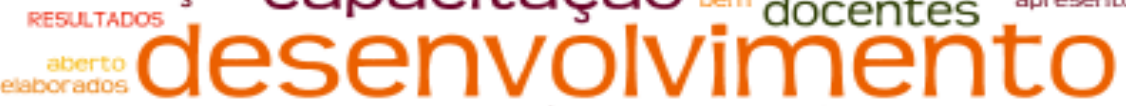

instrucional metodológica pedagógico horas cursos PAB computasores

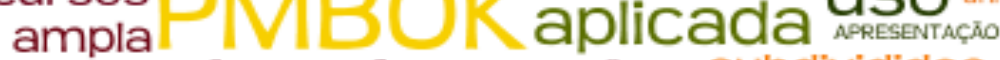

conhecimento subdivididos

permite digitais $\cap \mathrm{P} O \mathrm{O}$ descritiva restriçă assim informação gestão tooso Monitoramentosobre permeou $9<\mathbf{M U}^{\text {meio }}$ Articulate OUSUU duração in recursos In agens formatitos maior tutores livirraes SOftWare e-Learning ferramentas

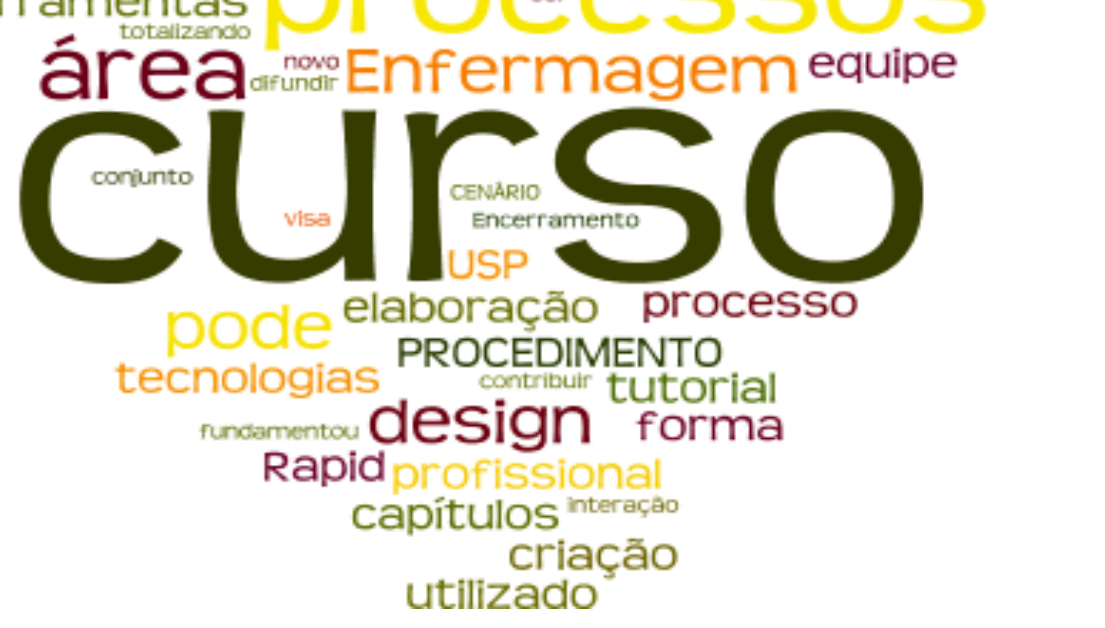

PROCEDIMENTO METODOLÓGICO 


\section{PROCEDIMENTO METODOLÓGICO}

\subsection{TIPO DE PESQUISA}

O estudo constituiu-se de uma pesquisa aplicada, de produção tecnológica com análise exploratório-descritiva com análise documental. A pesquisa metodológica foi escolhida por tratar-se de um processo de desenvolvimento/criação de um novo produto, atividade ou serviço, isto é, um ambiente virtual de aprendizagem para realização de um curso de capacitação profissional para o uso da TDIC como recurso pedagógico, planejado e gerenciado através do Guia PMBOK. Na pesquisa aplicada, o conceito de "aplicação" conduz a solução de problemas de interesse imediato para a sociedade em detrimento a sua relevância teórica. Atualmente o termo tem estado mais ligado ao desenvolvimento de novos produtos ou processos orientados às necessidades de mercado (APPOLINÁRIO, 2006; GIL, 2010).

A pesquisa exploratório-descritiva é usada quando o pesquisador tem a necessidade de definir o problema com maior precisão, identificar e descrever trajetórias de ação ou obter dados adicionais que possibilitem maior familiaridade com o problema a ser estudado (POLIT; BECK; HUNGLER, 2011). Segundo os mesmos autores, este tipo de pesquisa objetiva construir hipóteses mais adequadas, identificar melhor as variáveis e elaborar instrumentos para avaliação.

\subsection{CENÁRIO DO ESTUDO}

A pesquisa foi realizada por meio de um curso de capacitação de profissionais no uso de tecnologias digitais de informação e comunicação como recursos pedagógicos, realizado na Escola de Enfermagem da USP (EEUSP) em parceria com o Centro de Apoio à Escola de Enfermagem da USP (CEAP-EE) e o Departamento de Orientação Profissional (ENO), respeitando a Resolução CNE no 1, de 08/06/2007 e as Resoluções da Comissão de Cultura e Extensão Universitária no 4940, de 26/06/2002, 5857 de 19/05/2010 que define como curso de Atualização aquele que visa a difundir o progresso do conhecimento da área 
de enfermagem e afins, com no mínimo, trinta horas de duração e ministrado somente para já graduados.

O curso foi desenvolvido por meio de ambiente virtual de aprendizagem utilizando-se da plataforma moodle-rede aluno/USP. O Moodle (Modular Object Oriented Distance Learning) é um software Open Sourse (aberto, livre e gratuito), sendo distribuído sob a GNU (General Public License), o que proporciona constante melhoria de suas funcionalidades. Um software livre ou Free Software pode ser usado, copiado, estudado, modificado e redistribuído sem restrição (MOODLE, 2010).

Para o desenvolvimento do curso foram utilizados computadores do Centro de Teleenfermagem da EEUSP (CETENF-EEUSP), bem como o notebook das pesquisadoras. Com relação à edição de textos e de apresentação foram

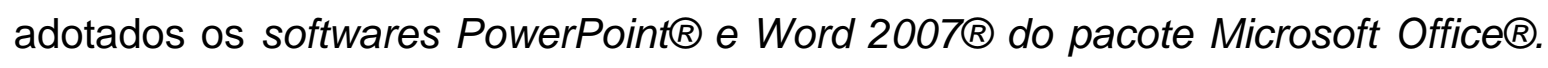
Para a criação dos objetos de aprendizagem foi utilizado o software de autoria Articulate Rapid e-Learning Studioß com a finalidade de ilustrar e proporcionar maior dinamicidade aos conteúdos selecionados e elaborados para o curso.

Esse programa apresenta um conjunto de ferramentas voltadas para criação de cursos online de forma rápida e eficaz na modalidade Rapid e-Learning. As principais vantagens proporcionadas pelo Articulate são as de desenvolver avaliações e conteúdos com elevado grau de interatividade, potencializar a utilização do PowerPoint como ferramenta de autoria, aproveitando o conhecimento já existente na organização sobre essa tecnologia, além de material pré-existente nesse formato e distribuir suas mensagens de forma ampla e em um formato que qualquer um pode visualizar.

Os editores de imagens adotados para o tratamento das imagens foram 0 Adobe Photoshop CS4® e o Picasa (software gratuito disponibilizado pelo Google®). Para o desenvolvimento do tutorial sobre arquivamento das imagens, foi utilizado o software create screen. As figuras e desenhos utilizados no curso foram obtidos por meio de banco de imagens gratuito e livre, como o da Microsoft®.

Com relação aos recursos humanos foram convidados docentes com ampla experiência na área de orientação profissional e formação de professores, assim como da área de design instrucional para o desenvolvimento dos objetos de 
aprendizagem, elaboração da tutorial e tratamento de imagens, vinculados a EEUSP.

O curso ocorreu no período de 15 de setembro a 14 de dezembro de 2015, contemplando uma carga horária de 90 horas a distância, composto por 09 módulos subdivididos conforme quadro 5 e programa do curso.

Quadro 5. Módulos do Curso de capacitação de profissionais no uso de tecnologias digitais de informação e comunicação como recursos pedagógicos.

\begin{tabular}{|c|c|c|}
\hline Temas & $\mathrm{CH}$ & Período \\
\hline Ambientação & $5 \mathrm{~h}$ & $1^{a}$ semana \\
\hline Cibercultura e Cyberespaço & $5 \mathrm{~h}$ & $2^{\mathrm{a}}$ semana \\
\hline O educador e o aprendiz na era digital & $15 \mathrm{~h}$ & $3^{\mathrm{a}}$ e $4^{\mathrm{a}}$ semanas \\
\hline O adulto como aprendiz na era digital & $5 \mathrm{~h}$ & $5^{\text {a }}$ semana \\
\hline Significar a aprendizagem na era digital & $5 \mathrm{~h}$ & $6^{\mathrm{a}}$ semana \\
\hline Metodologias ativas e as TDIC & $15 \mathrm{~h}$ & $7^{a}$ e $8^{\underline{a}}$ semanas \\
\hline $\begin{array}{l}\text { Metodologia dialética e a construção do conhecimento } \\
\text { na era digital }\end{array}$ & $5 \mathrm{~h}$ & 9as semana \\
\hline $\begin{array}{l}\text { Mediação da aprendizagem na era digital e as TDIC na } \\
\text { prática educativa. }\end{array}$ & $5 \mathrm{~h}$ & $10^{\mathrm{a}}$ semana \\
\hline Tecnologias digitais e a prática educativa & $30 \mathrm{~h}$ & $\begin{array}{l}11^{\mathrm{a}}, 12^{\mathrm{a}} \text { e } 13^{\mathrm{a}} \\
\text { semanas }\end{array}$ \\
\hline \multicolumn{3}{|c|}{$\begin{array}{l}\text { O curso totalizou } 13 \text { semanas de duração com atividades pedagógicas. A } \\
\text { ção do curso permeou todo este período prorrogando-se até o mês de } \\
\text { o. Estavam inseridos no AVA as regras do curso, o conteúdo base, o guia do } \\
\text { as matrizes instrucionais de cada módulo, as estratégias de ensino } \\
\text { íficas, as ferramentas síncronas e assíncronas, as relações dos tutores, os }\end{array}$} \\
\hline
\end{tabular}


processos avaliativos e os instrumentos de apoio e aprimoramento da aprendizagem.

O público-alvo, de demanda espontânea, foi composto por pesquisadores, educadores, tutores, docentes e coordenadores de cursos técnicos, de graduação, especialização e extensão, profissionais de educação continuada e corporativa, profissionais da área de saúde, gestão, comunicação e tecnologia, dos diversos estados brasileiros e de Portugal, totalizando 51 integrantes, entre eles 44 aprendizes e sete responsáveis técnicos pelo curso, integrantes da equipe de gerenciamento das atividades.

A equipe multidisciplinar foi composta pelos seguintes gerenciadores: gerente do projeto, gerente de processos, gerente pedagógico, designer instrucional, revisor, editores de conteúdos, professor/conteudista e tutores. $\mathrm{O}$ gerenciamento do projeto do curso foi baseado no guia PMBOK a partir da aplicação dos processos de Iniciação, Planejamento, Execução, Monitoramento e Controle e Encerramento. Estes processos foram distribuídos em dez áreas de conhecimento e subdivididos em instâncias descritas individualmente. Cada item apresentou uma análise específica juntamente com as observações pertinentes. 


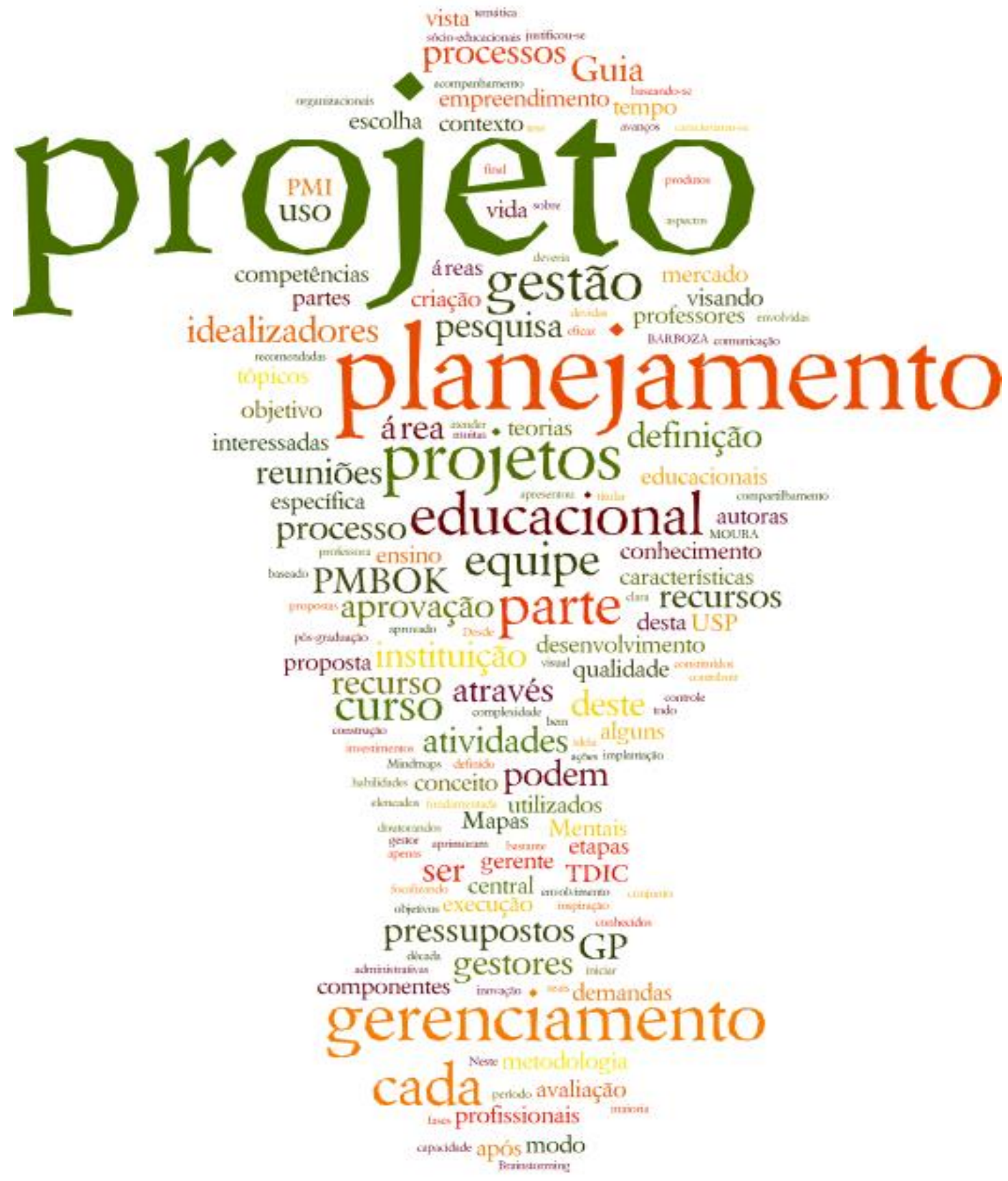

APRESENTAÇÃO DOS RESULTADOS 


\section{RESULTADOS}

O processo de início caracterizou-se, fundamentalmente, pela aprovação do projeto pelos gestores idealizadores (professores da USP e doutorandos do programa de pós-graduação). Em seguida, a gerente do projeto (professora associada na USP) solicitou aprovação da instituição de ensino, que após aprovação, possibilitou a alocação de recursos organizacionais ao projeto.

Uma vez aprovado pela instituição, os gestores idealizadores iniciaram o processo de planejamento do projeto, baseando-se em todas as áreas de conhecimento propostas pelo PMl e alguns fatores críticos elencados para o sucesso, como: apoio da instituição de ensino, definição clara dos objetivos, planejamento consistente com a realidade local, boa comunicação e feedback, envolvimento das partes interessadas, qualificação da equipe gestora, recursos suficientes, tecnologia comprovada e eficaz, cronograma realista e monitoramento contínuo.

Para melhor entender como foram constituídos todos os pressupostos, foi apresentado as características de cada grupo de processos e como as áreas de conhecimento foram correlacionadas ao ciclo de vida deste projeto. Também foi utilizado como recurso visual de associação, os Mapas Mentais, também conhecidos como Mindmaps, considerados um padrão mundial para criação, gerenciamento e compartilhamento de ideias.

Empregaram-se os Mapas Mentais para iniciar o conceito central e suas decomposições reflexivas, de modo a facilitar o entendimento do desenvolvimento do projeto.

\subsection{CICLO DE VIDA DO PROJETO}

Naturalmente este projeto pode ser visto panoramicamente através das fases do seu ciclo de vida. O conceito de ciclo de vida apoia a equipe de gestão a administrar de forma mais linear o projeto e os integrantes passam a obedecer aos requisitos de cada fase e o controle é vivenciado de forma mais profissional.

Neste projeto foi considerada a existência de cinco fases, abrangendo todo percurso desde a concepção ao encerramento, identificadas por Inicialização, 
Planejamento, Execução, Monitoramento e Controle, Encerramento. O tempo e o esforço empreendido em cada uma das fases deste projeto educacional estão representados na figura 9.

Figura 9. Ciclo de vida do projeto subdividido em fases.

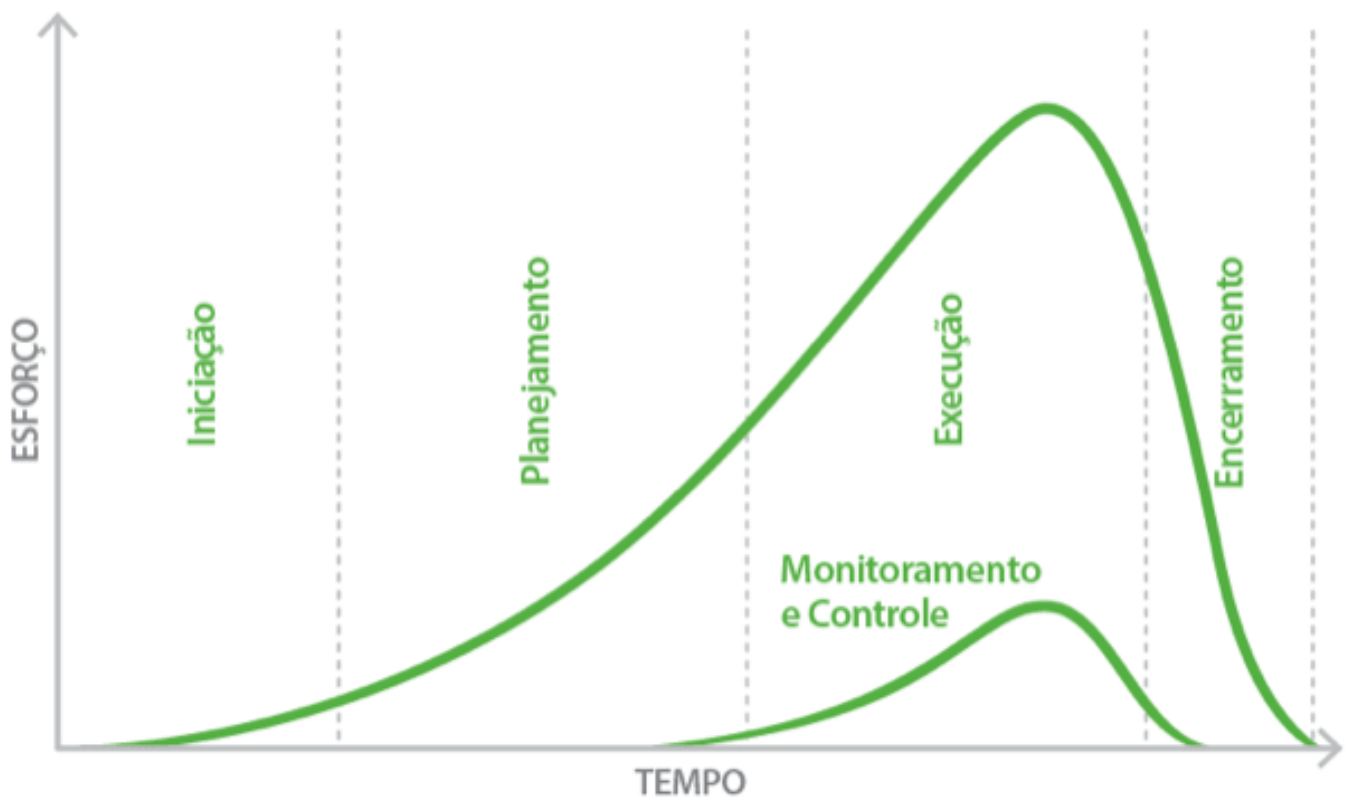

Fonte: Adaptado do Guia PMBOK, 2013.

Durante todo o projeto, alguns destes processos ocorreram de forma simultânea, principalmente a fase de planejamento que permeou todo processo de realização, por ser um elemento de caráter estrutural e de referência básica para sua execução, visando uma gestão ágil e flexível.

As dimensões de planejamento referiram-se a elaboração dos documentos básicos e planos de trabalho (a estrutura do projeto), já a dimensão de gestão envolveu ao modelo de gerenciamento, controle e condução do projeto (a operacionalidade do projeto).

As fases de planejamento e execução envolveram a equipe do projeto na busca da clareza da identificação das demandas, a formulação de objetivos factíveis e dimensionados a capacidade de realização das equipes, planos, tarefas, atividades bem elaboradas, definição de instrumentos e mecanismos de 
implantação e avaliação. Estas fases visaram o entendimento a respeito de tudo que deveria ser feito, bem como seus motivos e finalidades.

Os componentes da equipe, por sua vez, que vivenciaram as cinco fases, alcançaram um intenso envolvimento com todos os aspectos relacionados com o projeto, com os resultados esperados e com os meios concebidos para alcançalos, envolvendo necessariamente, as dimensões de planejamento e gestão.

\subsection{GRUPO DE PROCESSOS}

No PMI as fases do ciclo de vida fundamentam o modelo do processo de gerenciamento de projetos. Os grupos de processos gerenciais caracterizam um conjunto de atividades distintas, das quais resultam diferentes produtos deste a iniciação ao encerramento.

Figura 10. Mapa mental do grupo de processos de gestão de processos do PMI.

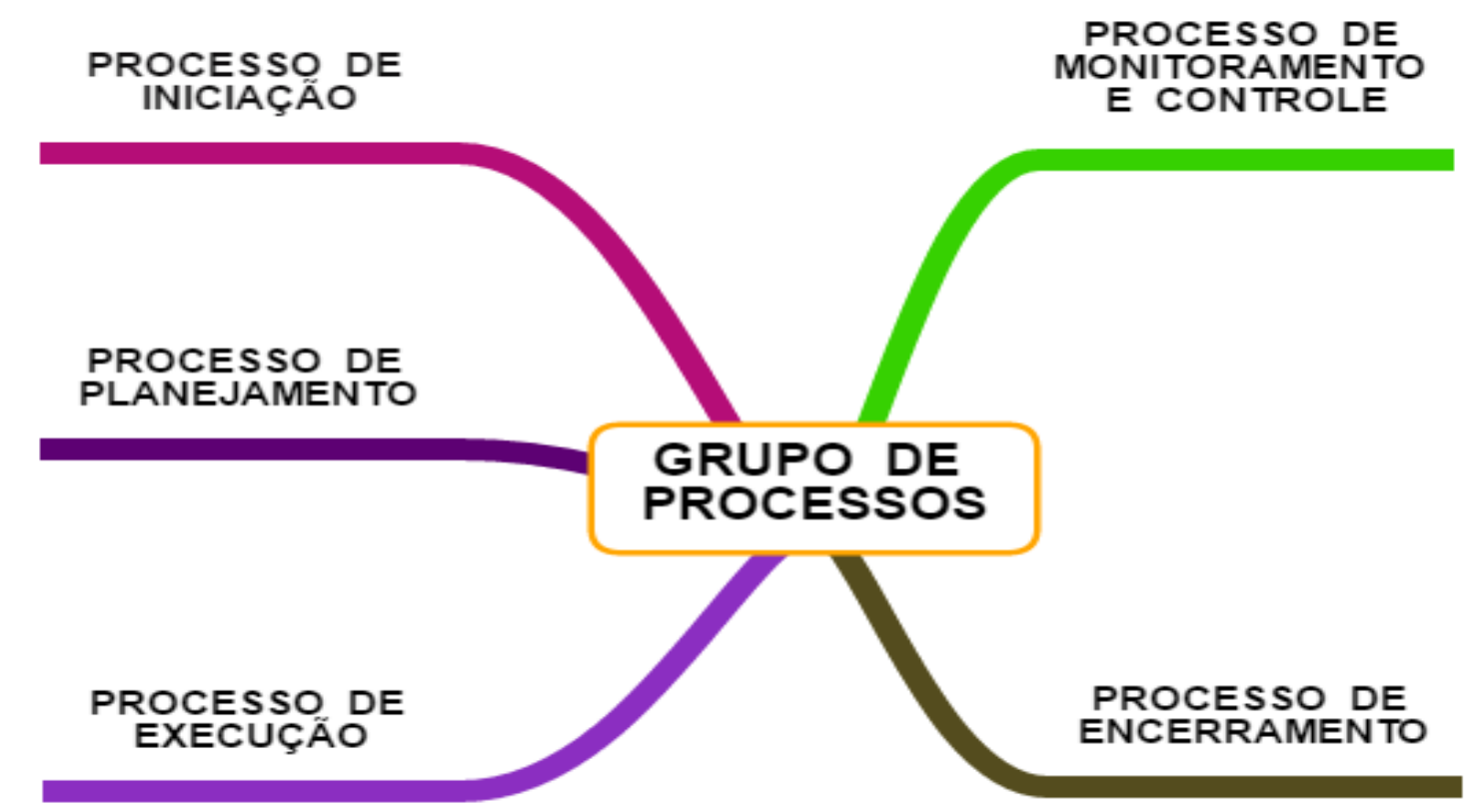

Fonte: A autora (2016).

O processo de iniciação foi o ponto em que o projeto foi elaborado, aprovado e iniciado. Foi considerado pela equipe a importância de implantar um curso de aperfeiçoamento docente no uso das TDIC na modalidade de EAD através de processos específicos que garantissem eficiência e eficácia as ações 
educativas com um olhar gerencial as questões pedagógicas, administrativas e tecnológicas.

As atividades relacionadas ao processo de iniciação foram:

1. Identificação da situação motivadora para efetivação do projeto;

2. Definição das metas principais do projeto educacional, consistindo em Capacitar os cursistas para a utilização das TDIC na prática educativa.

3. Definição dos critérios de seleção dos gestores do projeto, permanecendo as professoras associadas da USP, as doutorandas convidadas a integrar a pesquisa e as tutoras virtuais, mestres em enfermagem com ênfase em tecnologias educativas.

4. Definição do escopo preliminar do projeto.

5. Definição dos critérios de seleção dos cursistas que foram: serem pesquisadores, educadores, docentes e coordenadores de cursos técnicos, de graduação, especialização e extensão, profissionais de educação continuada e corporativa e aqueles que desejam investir na sua formação visando a aplicabilidade das TDIC como recurso educacional.

6. Diagnóstico e coleta de informações acerca dos cursistas, suas demandas técnicas, operacionais e pedagógicas.

7. Definição do modelo do curso: um aperfeiçoamento profissional para o uso das TDIC como recursos pedagógicos, totalmente a distância.

8. Estimativa de custos e orçamento.

9. Elaboração do Termo de abertura do projeto, também denominado Project Charter, documento com a descrição do projeto, seus objetivos, equipe gestora, orçamento, cronograma e detalhamento das atividades.

10. Abertura do projeto juntamente a instituição proponente, ou seja, o envio da proposta de uma atividade de formação profissional de educação continuada e curso de difusão juntamente a Pró-Reitoria de Cultura e Extensão Universitária da Universidade de São Paulo, com seus aspectos gerenciais, acadêmicos e financeiros.

11. Liberação da Pró-Reitoria para efetivação do curso juntamente ao Departamento de Orientação Educacional da Escola de Enfermagem da USP. 
O processo de planejamento foi o âmago dos processos de gerenciamento deste projeto. Os documentos produzidos durante este processo foram usados em todos os processos restantes do projeto para realização das atividades e monitoramento do seu progresso. As atividades realizadas nesta etapa foram:

1. Planejamento e definição do escopo.

2. Definição da estrutura de design instrucional dos materiais e ambiente virtual.

3. Definição do início do curso, que ocorreu em setembro de 2015.

4. Formulação da proposta didático-pedagógica, baseada em pressupostos teóricos.

5. Descrição das atividades estratégicas do curso e seu sequenciamento, como: definição dos módulos, ementas, caracterização das aulas, cronograma, materiais complementares, escolha dos ambientes virtuais e recursos tecnológicos de apoio, critérios de aprovação e certificação, assim como direitos autorais a equipe de elaboração.

6. Definição dos recursos necessários: gestores, tutores, design instrucional, equipe administrativa para inscrição dos cursistas, equipe de tecnologia da informação da instituição proponente.

7. Definição do processo de inscrição dos cursistas, junto a instituição proponente.

8. Planejamento do processo de atendimento aos cursistas, presencialmente e a distância, desde o processo de inscrição até o encerramento do curso.

9. Elaboração do cronograma, que compreendeu 6 meses de iniciação e planejamento, 3 meses de execução, monitoramento e controle e mais 2 meses de fechamento.

10. Planejamento da qualidade do curso.

11. Identificação e análise dos riscos.

12. Pré-produção do curso. 
A execução foi o processo de produção do projeto. Foi nesta fase que todas as ações elaboradas nos processos de iniciação e planejamento ganharam vida, os recursos foram aplicados e o cronograma teve que ser cumprido efetivamente. Neste processo foram realizadas as seguintes providências:

1. Mobilização da equipe do projeto e compartilhamento dos conhecimentos.

2. Divulgação do curso em meios de comunicação internos e externos.

3. Realização das matrículas das partes interessadas.

4. Liberação do curso na plataforma moodle aos cursistas, de acordo com o cronograma.

5. Ativação da equipe para realização de suas atividades específicas de gestão, docência e tutoria no curso.

6. Coordenação das gerentes de projeto nas atividades semanais do curso.

7. Comunicação efetiva entre os stackholders para resolução de conflitos e pendências.

8. Gerenciamento das expectativas dos cursistas, seus avanços e dificuldades.

9. Implementação das atividades pedagógicas com aplicação do conteúdo e atividades acadêmicas, bem como modelagem do ambiente virtual.

10. Reorganização do planejamento frente a dificuldades encontradas.

O processo de monitoramento e controle do projeto ocorreu paralelamente aos demais processos e contribuiu para a avaliação de cumprimento dos objetivos traçados no planejamento, realização de alterações do planejamento e elaboração dos relatórios de progresso. Foi necessário nesta fase rever o planejamento e a execução para realizar as ações corretivas. Neste momento do projeto ocorreu a "gestão de mudanças", onde foram revistas algumas atividades. $\mathrm{O}$ grupo de processos de monitoramento e controle também envolveu: 
1. Controle integrado das mudanças e recomendação de ações corretivas (alteração de cronogramas, inclusão de materiais didáticos e ampliação da equipe de tutores).

2. Monitoramento das atividades contínuas do projeto em relação ao plano de gerenciamento do projeto (atividades, postagens nos ambientes virtuais distintos, feedback entre as partes envolvidas).

O processo de encerramento, também conhecida como fase de aprendizado, foi uma das etapas mais importantes do projeto. Foi neste momento do ciclo de vida que se comemorou o êxito do projeto, documentando-se o que aprendido, concluindo o curso oferecido e transformando os resultados em publicações. Algumas providências foram tomadas:

1. Finalização de todos os objetivos traçados no curso.

2. Encerramento dos contratos.

3. Documentação das lições aprendidas.

4. Arquivamento dos registros do projeto e relatos dos cursistas.

5. Avaliação dos rendimentos individuais de cada cursista participante.

6. Elaboração dos relatórios institucionais.

7. Definição se o mesmo projeto educacional será novamente aplicado, pela mesma equipe, na mesma instituição de ensino, na mesma modalidade.

\section{4 ÁREAS DE CONHECIMENTO PARA GERENCIAMENTO DO PROJETO}

Definidos os grupos de processos, segue-se para a análise das áreas de conhecimento por grupo, de acordo com o cenário peculiar do empreendimento realizado neste projeto. A proposta de planejar um projeto educacional em EAD como razão desta obra faz-se detalhada adiante, servindo como um mapa de possibilidades a serem observadas neste desafio: planejar e gerir processos educacionais de forma eficiente utilizando-se de tecnologias para aperfeiçoamento docente.

Os processos de gerenciamento de projetos são estruturas específicas classificadas por especialidade, onde ocorrem as atividades necessárias a 
realização do curso. Estas estruturas são divididas em áreas de conhecimento, de forma a garantir melhor distribuição do projeto em forma modularizada. Vale relembrar que no modelo de gestão do PMl têm-se 47 processos de gerenciamento divididos em dez áreas de conhecimento. As áreas de conhecimento são apresentadas na Figura 11.

Figura 11. Mapa Mental das áreas de conhecimento do Guia PMBOK.

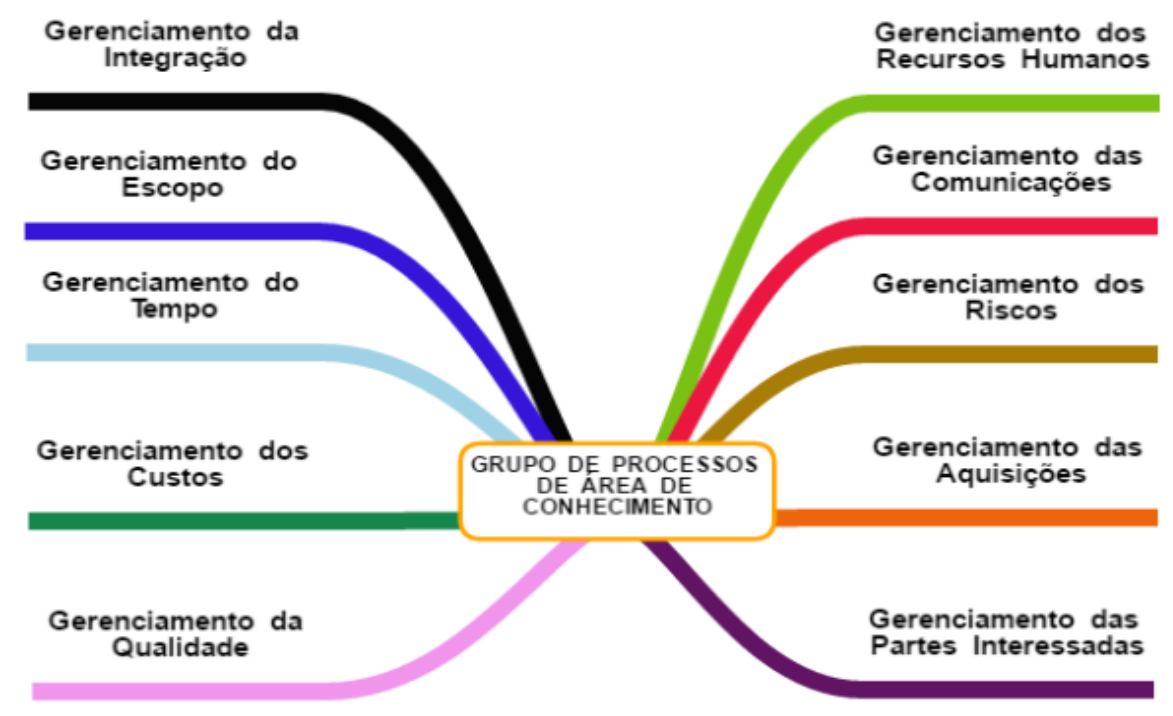

Fonte: A autora (2016).

Para inclusão das diretrizes em consonância com as orientações do Guia PMBOK, as dez áreas de conhecimento foram selecionadas pela equipe do projeto, uma vez que elas englobam todas as ações gerenciais de um curso a distância, todavia, de acordo com o perfil do projeto, utilizou-se somente parte destes processos.

\subsubsection{GERENCIAMENTO DA INTEGRAÇÃO DO PROJETO}

O gerenciamento da integração do projeto inclui os processos e atividades para identificar, definir, combinar e coordenar os vários processos e atividades dentro dos grupos de processos. No contexto de gerenciamento de projetos, integração inclui características de unificação, consolidação, comunicação e ações integradoras que são essenciais para a execução controlada do projeto até 
a sua conclusão, a fim de gerenciar com sucesso as expectativas das partes interessadas e atender aos objetivos definidos (PMBOK, 2013).

Os processos de gerenciamento da integração se decompõem conforme o Mapa Mental a seguir:

Figura 12. Mapa Mental dos processos e ações envolvidas no Gerenciamento da Integração.

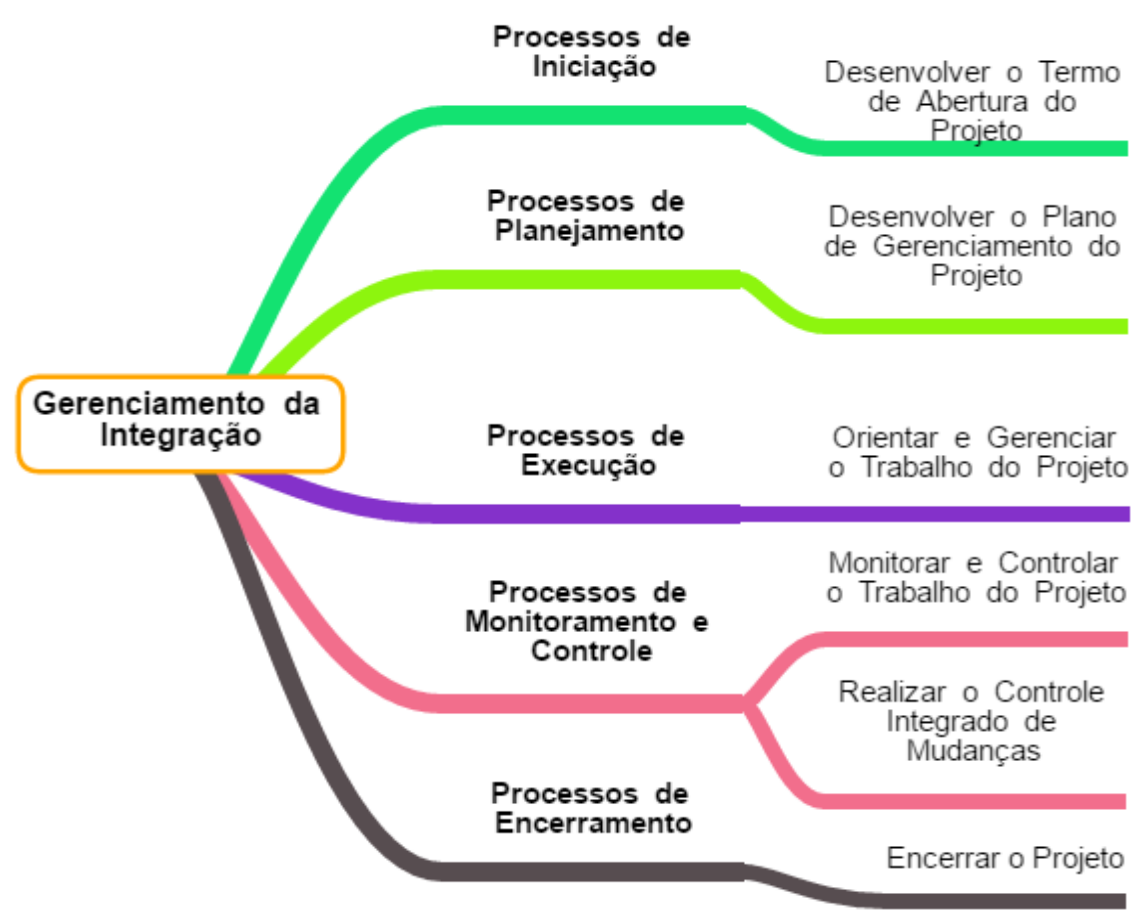

Fonte: A autora (2016).

A integração exerceu papel essencial no gerenciamento do projeto do curso, à medida que, criou condições propícias para o desenvolvimento do projeto através do estabelecimento do objetivo geral de capacitar profissionais no uso de TDIC como recursos pedagógicos através da EAD baseando-se na aprendizagem significativa, no uso da metodologia dialética e das metodologias ativas, vinculadas a mediação da aprendizagem na era digital.

O primeiro passo foi a elaboração do Termo de Abertura do Projeto, também denominado pelo PMI de Project Charter, que consistiu no preenchimento de uma documentação que autorizava formalmente a existência do curso junto a Pró-Reitoria de Cultura e Extensão Universitária da Universidade de São Paulo e ao Departamento de Orientação Profissional da Escola de Enfermagem da Universidade de São Paulo. O Project Charper foi também usado para estabelecer 
acordos internos no âmbito da própria equipe para garantir a entrega nos termos do contrato.

O termo de abertura utilizado era padronizado institucionalmente e continha informações vinculadas à caracterização acadêmica do curso, tais como: unidade proponente, natureza da formação profissional proposta por um curso de atualização na modalidade EAD, público-alvo, profissionais responsáveis, justificativa do projeto, objetivo geral e específicos, programa do curso, carga horária, processo de inscrição dos cursistas e critérios de seleção, política de isenções, número de vagas, critérios de aprovação; e informações vinculadas a sua caracterização financeira, com dados referentes a taxas de inscrição, convênios, aplicação das receitas estimadas e resultado financeiro previsto.

O segundo processo foi desenvolvimento do Plano de Gerenciamento do Projeto (PGP), que definiu todas as etapas do curso, integrando-as em um plano único de gestão. Um dos principais desafios deste projeto foi acertar um plano onde estivessem representadas todas as preocupações a serem administradas, integrando as áreas de conhecimento descritas no PMI com as preocupações específicas do projeto educacional.

O PGP do curso considerou, inicialmente, os elementos organizacionais tais como: objetivo geral, específicos, as estratégias e como o projeto estaria alinhado a tudo isso, assim como ações, atividades, tarefas, recursos e cronograma (Quadro 6). Neste momento também foi elaborado o Plano de Monitoramento e Avaliação (PMA) para monitoramento e avaliação sistemática da execução e resultados do projeto, com planilhas de acompanhamento e instrumento de coleta de dados.

Entre as condições visualizadas durante a elaboração do PGP, destaca-se: a clareza na definição dos objetivos a serem atingidos durante todas as etapas do curso de forma factível, dimensionados de acordo com a capacidade de realização da equipe do projeto, assim como cronogramas bem elaborados, viabilizando o cumprimento dos prazos de cada unidade do curso, assim como a finalização das atividades sugeridas. 
Quadro 6. Plano de gerenciamento do projeto do curso.

\begin{tabular}{|c|c|c|}
\hline $\begin{array}{l}\text { Nome do Projeto } \\
\text { Curso de Atualização: } \\
\text { Tecnologias Digitais de } \\
\text { Informação e Comunicação } \\
\text { na Educação }\end{array}$ & $\begin{array}{l}\text { Gerentes } \\
\text { Profa. Cláudia Prado } \\
\text { Profa. Maria Madalena } \\
\text { Januário Leite }\end{array}$ & $\begin{array}{l}\text { Instituição } \\
\text { Escola de Enfermagem da } \\
\text { Universidade de São Paulo }\end{array}$ \\
\hline \multicolumn{3}{|c|}{$\begin{array}{l}\text { Objetivo Geral } \\
\text { Capacitar profissionais no uso de TDIC como recursos pedagógicos através da EAD. }\end{array}$} \\
\hline \multicolumn{3}{|c|}{$\begin{array}{l}\text { Objetivos Específicos } \\
\text { Apresentar os fundamentos pedagógicos e metodológicos que norteiam o uso de tecnologias } \\
\text { digitais de informação e comunicação na educação; } \\
\text { Promover a reflexão sobre os novos cenários de aprendizagem na cibercultura e a importância } \\
\text { da inclusão das tecnologias digitais para a inovação das práticas pedagógicas; }\end{array}$} \\
\hline
\end{tabular}

ESCOPO DO PROJETO

\begin{tabular}{|c|c|c|c|c|c|}
\hline \multicolumn{6}{|c|}{$\begin{array}{l}\text { Carga Horária } \\
90 \text { horas/aula }\end{array}$} \\
\hline \multicolumn{6}{|c|}{$\begin{array}{l}\text { Total de vagas } \\
50 \text { vagas }\end{array}$} \\
\hline \multicolumn{6}{|c|}{ MATRIZ DE DESIGN INSTRUCIONAL GERAL } \\
\hline Unidade & Cronograma & Tema & Objetivo & $\begin{array}{l}\text { Ferramentas } \\
\text { e Conteúdos }\end{array}$ & Avaliação \\
\hline 1 & $\begin{array}{c}15.09 .15 \mathrm{a} \\
21.09 .15\end{array}$ & Ambientação & $\begin{array}{c}\text { Conhecer o } \\
\text { ambiente virtual } \\
\text { de aprendizagem; } \\
\text { Apresentar a } \\
\text { proposta do curso; } \\
\text { Identificar as } \\
\text { etapas do curso, } \\
\text { os integrantes, as } \\
\text { atividades e a } \\
\text { proposta final de } \\
\text { trabalho. }\end{array}$ & $\begin{array}{c}\text { Fórum de } \\
\text { apresentação; } \\
\text { Blog; } \\
\text { Vídeos; } \\
\text { Fórum de } \\
\text { dúvidas. }\end{array}$ & \\
\hline 2 & $\begin{array}{c}22.09 .15 \mathrm{a} \\
28.09 .15\end{array}$ & $\begin{array}{c}\text { Cibercultura e } \\
\text { Ciberespaço }\end{array}$ & $\begin{array}{l}\text { Compreender as } \\
\text { proposições } \\
\text { acerca da nova } \\
\text { relação que o ser } \\
\text { humano } \\
\text { estabelece com o } \\
\text { saber, agora que } \\
\text { esta imerso na } \\
\text { cibercultura; } \\
\text { Identificar os } \\
\text { preceitos sobre } \\
\text { cibercultura e } \\
\text { ciberespaço. }\end{array}$ & $\begin{array}{l}\text { Literatura } \\
\text { digital; } \\
\text { Vídeos; } \\
\text { Fórum de } \\
\text { dúvidas; } \\
\text { Biblioteca } \\
\text { virtual }\end{array}$ & $\begin{array}{l}\text { Construção do } \\
\text { infográfico }\end{array}$ \\
\hline
\end{tabular}




\begin{tabular}{|c|c|c|c|c|c|}
\hline 3 & $\begin{array}{c}29.09 .15 \mathrm{a} \\
12.10 .15\end{array}$ & $\begin{array}{l}\text { O educador e } \\
\text { o aprendiz na } \\
\text { era digital: } \\
\text { configurando } \\
\text { novos perfis }\end{array}$ & $\begin{array}{c}\text { Reconhecer } \\
\text { alguns desafios } \\
\text { enfrentados por } \\
\text { educadores e } \\
\text { aprendizes diante } \\
\text { dos diferentes } \\
\text { tipos de } \\
\text { tecnologias } \\
\text { educacionais que } \\
\text { poderão ser } \\
\text { utilizadas na } \\
\text { prática educativa; } \\
\text { Vivenciar a } \\
\text { experiência de } \\
\text { uma estratégia de } \\
\text { ensino que } \\
\text { possibilite ao } \\
\text { aprendiz a } \\
\text { responsabilidade } \\
\text { pelo seu } \\
\text { conhecimento; }\end{array}$ & $\begin{array}{l}\text { Literatura } \\
\text { digital; } \\
\text { Webquest; } \\
\text { Vídeos; } \\
\text { Fórum de } \\
\text { dúvidas; } \\
\text { Biblioteca } \\
\text { virtual }\end{array}$ & $\begin{array}{l}\text { Construção de } \\
\text { uma História } \\
\text { em Quadrinhos } \\
\text { em aplicativo } \\
\text { virtual }\end{array}$ \\
\hline 4 & $\begin{array}{c}13.10 .15 \mathrm{a} \\
19.10 .15\end{array}$ & $\begin{array}{l}\text { O adulto } \\
\text { como } \\
\text { aprendiz na } \\
\text { era digital }\end{array}$ & $\begin{array}{c}\text { Compreender as } \\
\text { características } \\
\text { dos adultos como } \\
\text { aprendizes, } \\
\text { relacionando-as } \\
\text { com os princípios } \\
\text { andragógicos; } \\
\text { Identificar os } \\
\text { princípios } \\
\text { andragógicos } \\
\text { contemplados nas } \\
\text { aulas já } \\
\text { percorridas do } \\
\text { curso; Refletir } \\
\text { acerca da } \\
\text { aplicabilidade da } \\
\text { andragogia na } \\
\text { prática educativa. }\end{array}$ & $\begin{array}{l}\text { Literatura } \\
\text { digital; } \\
\text { Vídeos; } \\
\text { Biblioteca } \\
\text { virtual; } \\
\text { Fórum de } \\
\text { dúvidas }\end{array}$ & $\begin{array}{l}\text { Composição } \\
\text { de um texto } \\
\text { coletivo na } \\
\text { Wiki }\end{array}$ \\
\hline 5 & $\begin{array}{c}20.10 .15 a \\
26.10 .15\end{array}$ & $\begin{array}{c}\text { Significar a } \\
\text { aprendizage } \\
\text { m na era } \\
\text { digital }\end{array}$ & $\begin{array}{l}\text { Identificar os } \\
\text { princípios da } \\
\text { Teoria da } \\
\text { Aprendizagem } \\
\text { Significativa; } \\
\text { Refletir sobre } \\
\text { aplicabilidade dos } \\
\text { conceitos e } \\
\text { princípios da } \\
\text { Teoria da } \\
\text { Aprendizagem } \\
\text { Significativa no }\end{array}$ & $\begin{array}{l}\text { Literatura } \\
\text { digital; } \\
\text { Vídeos; } \\
\text { Biblioteca } \\
\text { virtual; } \\
\text { Fórum de } \\
\text { dúvidas }\end{array}$ & $\begin{array}{l}\text { Criação de } \\
\text { uma Nuvem de } \\
\text { palavras em } \\
\text { aplicativo } \\
\text { virtual }\end{array}$ \\
\hline
\end{tabular}




\begin{tabular}{|c|c|c|c|c|c|}
\hline & & & $\begin{array}{c}\text { planejamento de } \\
\text { práticas } \\
\text { educativas. }\end{array}$ & & \\
\hline 6 & $\begin{array}{c}27.10 .15 \mathrm{a} \\
09.11 .15\end{array}$ & $\begin{array}{c}\text { Metodologias } \\
\text { ativas e as } \\
\text { TDIC }\end{array}$ & $\begin{array}{c}\text { Conhecer as } \\
\text { metodologias } \\
\text { ativas e sua } \\
\text { aplicabilidade nas } \\
\text { práticas } \\
\text { educativas; } \\
\text { Refletir sobre as } \\
\text { características } \\
\text { desejáveis aos } \\
\text { educadores que } \\
\text { pretendem utilizar } \\
\text { metodologias } \\
\text { ativas. }\end{array}$ & $\begin{array}{l}\text { Literatura } \\
\text { digital; } \\
\text { Vídeos; } \\
\text { Biblioteca } \\
\text { virtual; } \\
\text { Fórum de } \\
\text { dúvidas }\end{array}$ & $\begin{array}{c}\text { Postagem de } \\
\text { uma } \\
\text { Fotografia que } \\
\text { represente as } \\
\text { metodologias } \\
\text { ativas }\end{array}$ \\
\hline 7 & $\begin{array}{c}10.11 .15 \mathrm{a} \\
16.11 .15\end{array}$ & $\begin{array}{c}\text { Metodologia } \\
\text { dialética e a } \\
\text { construção do } \\
\text { conhecimento } \\
\text { na era digital }\end{array}$ & $\begin{array}{l}\text { Identificar as } \\
\text { fases da } \\
\text { construção do } \\
\text { conhecimento na } \\
\text { perspectiva da } \\
\text { teoria dialética; } \\
\text { Compreender as } \\
\text { dimensões da } \\
\text { metodologia } \\
\text { dialética como } \\
\text { recursos para } \\
\text { organizar a prática } \\
\text { educativa e } \\
\text { mediar a } \\
\text { construção do } \\
\text { conhecimento. }\end{array}$ & $\begin{array}{l}\text { Literatura } \\
\text { digital; } \\
\text { Vídeos; } \\
\text { Mapa } \\
\text { conceitual; } \\
\text { Glossário; } \\
\text { Biblioteca } \\
\text { virtual; } \\
\text { Fórum de } \\
\text { dúvidas }\end{array}$ & $\begin{array}{c}\text { Planejamento } \\
\text { de uma prática } \\
\text { educativa } \\
\text { utilizando TDIC }\end{array}$ \\
\hline 8 & $\begin{array}{c}17.11 .15 \mathrm{a} \\
23.11 .15\end{array}$ & $\begin{array}{c}\text { Mediação da } \\
\text { aprendizage } \\
\text { m na era } \\
\text { digital }\end{array}$ & $\begin{array}{l}\text { Compreender o } \\
\text { conceito de } \\
\text { mediação } \\
\text { pedagógica; } \\
\text { Delinear o papel } \\
\text { do educador como } \\
\text { mediador do } \\
\text { processo de } \\
\text { construção do } \\
\text { conhecimento. }\end{array}$ & $\begin{array}{l}\text { Literatura } \\
\text { digital; } \\
\text { Vídeos; } \\
\text { Áudio; } \\
\text { Fórum de } \\
\text { dúvidas; } \\
\text { Biblioteca } \\
\text { virtual. }\end{array}$ & $\begin{array}{c}\text { Confecção de } \\
\text { uma síntese do } \\
\text { tema e } \\
\text { construção de } \\
\text { um card com } \\
\text { apoio do } \\
\text { aplicativo } \\
\text { Quozio. }\end{array}$ \\
\hline 9 & $\begin{array}{c}24.11 .15 \mathrm{a} \\
14.12 .15\end{array}$ & $\begin{array}{c}\text { As TDIC e a } \\
\text { prática } \\
\text { educativa }\end{array}$ & $\begin{array}{c}\text { Refletir acerca } \\
\text { dos limites e } \\
\text { possibilidades das } \\
\text { TDIC para } \\
\text { construção de } \\
\text { práticas } \\
\text { pedagógicas } \\
\text { inovadoras. }\end{array}$ & $\begin{array}{l}\text { Literatura } \\
\text { digital; } \\
\text { Vídeos; } \\
\text { Fórum de } \\
\text { dúvidas; } \\
\text { Biblioteca } \\
\text { virtual. }\end{array}$ & $\begin{array}{l}\text { Instrumento de } \\
\text { avaliação do } \\
\text { curso: } \\
\text { Elaboração de } \\
\text { uma Narrativa } \\
\text { Digital }\end{array}$ \\
\hline
\end{tabular}




\begin{tabular}{|c|c|}
\hline \multicolumn{2}{|c|}{$\begin{array}{l}\text { Ferramentas comuns em todas as unidades de aprendizagem: } \\
\text { Apresentação da aula; Roteiro de aprendizagem; Avaliação; Fórum de dúvidas e Biblioteca } \\
\text { virtual. }\end{array}$} \\
\hline \multicolumn{2}{|c|}{$\begin{array}{l}\text { Tecnologias comuns em todas as unidades de aprendizagem: } \\
\text { Moodle, Blog; Email, Facebook. }\end{array}$} \\
\hline \multicolumn{2}{|c|}{$\begin{array}{l}\text { Proposta Avaliativa: } \\
\text { Frequência de } 85 \% \text { nas unidades mediante entrega das atividades. }\end{array}$} \\
\hline \multicolumn{2}{|c|}{ MATRIZ DE RESPONSABILIDADES DA EQUIPE } \\
\hline Gerente do Projeto (2) & $\begin{array}{l}\text { Coordenação das equipes e acompanhamento dos trabalhos } \\
\text { desenvolvidos; Elaboração do Plano do Projeto; Coordenação das } \\
\text { reuniões de planejamento, desenvolvimento e avaliação parcial e } \\
\text { final do curso junto aos professores e tutores; Análise semanal do } \\
\text { relatório enviado pelos tutores a respeito: da mobilidade dos } \\
\text { alunos nas aulas, as postagens das tarefas, as dificuldades } \\
\text { pedagógicas surgidas; Acompanhamento da mediação realizada } \\
\text { pelos tutores; Acompanhamento da avaliação da aprendizagem } \\
\text { dos cursistas; Participação no Blog e no Facebook; Manutenção } \\
\text { da ética ao longo do curso; Manutenção do contato com a equipe } \\
\text { administrativa e de TI para acompanhamento e avaliação do } \\
\text { curso; Elaboração do relatório final do curso para prestação de } \\
\text { contas; Prestação de esclarecimentos pedagógicos, } \\
\text { administrativos e financeiros à direção da instituição proponente, } \\
\text { sempre que necessário; }\end{array}$ \\
\hline $\begin{array}{c}\text { Professores/ } \\
\text { Coordenadores de } \\
\text { Unidades de } \\
\text { Aprendizagem/Conteúdistas } \\
\text { (3) }\end{array}$ & $\begin{array}{l}\text { Elaboração das unidades; Definição das metodologias, } \\
\text { referenciais teóricos, materiais, recursos tecnológicos e } \\
\text { atividades; Monitoração e controle do AVA, Email e do Blog } \\
\text { diariamente; Avaliação das atividades postadas e emissão de } \\
\text { feedback aos cursistas; Motivação dos cursistas frente aos } \\
\text { desafios e a participação; Construção de vínculo de cooperação e } \\
\text { interação entre os cursistas; Criação de um clima acolhedor; } \\
\text { Gerenciamento de conflitos que possam surgir no decorrer do } \\
\text { curso; Articulação do material didático aos saberes trazidos pelos } \\
\text { cursistas; Envolvimento dos cursistas em atividades reflexivas; } \\
\text { Feedback ao cursista em até } 48 \text { horas; Acompanhamento do } \\
\text { desempenho do cursista e enriquecimento da aprendizagem; } \\
\text { Estimulação da aprendizagem colaborativa e a a a } \\
\text { corresponsabilidade no processo de todos os envolvidos; } \\
\text { Adequação da linguagem e postura na mediação; Construção de } \\
\text { uma mediação incentivadora para os cursistas que tenham mais } \\
\text { dificuldade no tocante à fluência tecnológica; Reflexão sobre sua } \\
\text { prática, análise das fragilidades encontradas e elaboração de } \\
\text { estratégias de superação; Participação no Blog e Facebook. }\end{array}$ \\
\hline Tutores/Motivadores (2) & $\begin{array}{l}\text { Tabulação da movimentação dos cursistas; Arquivamento das } \\
\text { mensagens postadas; Arquivamento das dúvidas dos cursistas; } \\
\text { Postagens no Facebook; Acompanhamento das atividades; } \\
\text { Mediação dos fóruns e dúvidas; Elaboração e preenchimento das }\end{array}$ \\
\hline
\end{tabular}




\begin{tabular}{|c|l|}
\hline & planilhas de Monitoramento e Controle. \\
\hline Design Instrucional (1) & Criação do design gráfico do AVA e Tutor virtual. \\
\hline $\begin{array}{c}\text { Equipe Administrativa/ } \\
\text { Analistas de Suporte } \\
\text { Técnico (2) }\end{array}$ & $\begin{array}{l}\text { Divulgação do evento; Inscrições; Controle Financeiro. Promoção } \\
\text { de condutas administrativas que zelem pela boa qualidade do } \\
\text { curso (documentação, pagamento, supervisão da parceria com a } \\
\text { instituição proponente); }\end{array}$ \\
\hline $\begin{array}{c}\text { Equipe de Tl/ Analistas de } \\
\text { Suporte Técnico (1) }\end{array}$ & $\begin{array}{l}\text { Monitoramento e Controle da usabilidade e acessibilidade do } \\
\text { ambiente virtual de aprendizagem. }\end{array}$ \\
\hline
\end{tabular}

\section{CRONOGRAMA DE REUNIÕES DA EQUIPE}

\begin{tabular}{|c|c|c|}
\hline Gestores e Professores & 05.02 .15 & Reunião presencial \\
\hline Gestores, Professores e Design Instrucional & 05.03 .15 & Reunião presencial \\
\hline Gestores e Equipe TI & 10.03 .15 & Reunião presencial \\
\hline Gestores e Equipe Administrativa & 01.04 .15 & Reunião presencial \\
\hline Gestores e Professores & 05.04 .15 & Reunião presencial \\
\hline Gestores e Professores & 05.05 .15 & Reunião online \\
\hline Gestores e Professores & 05.06 .15 & Reunião presencial \\
\hline Gestores e Equipe Administrativa & 14.09 .15 & Reunião presencial \\
\hline Gestores e Professores & 05.07 .15 & Reunião online \\
\hline Gestores, Professores e Tutores & 05.08 .15 & Reunião presencial \\
\hline Gestores, Professores e Tutores & 15.09 .15 & Reunião online \\
\hline Gestores, Professores e Tutores & 22.09 .15 & Reunião online \\
\hline Gestores, Professores e Tutores & 28.09 .15 & Reunião online \\
\hline Gestores e Professores & 13.10 .15 & Reunião online \\
\hline Gestores, Professores e Tutores & 29.09 .15 & Reunião presencial \\
\hline Gestores, Professores e Tutores & 13.10 .15 & Reunião online \\
\hline Gestores, Professores e Tutores & 20.10 .15 & Reunião online \\
\hline Gestores, Professores e Tutores & 27.10 .15 & Reunião online \\
\hline Gestores, Professores e Tutores & 10.11 .15 & Reunião presencial \\
\hline Gestores, Professores e Tutores & 17.11 .15 & Reunião online \\
\hline Gestores, Professores e Tutores & 25.11 .15 & Reunião online \\
\hline Gestores, Professores e Tutores & 21.12 .15 & Reunião presencial \\
\hline Gestores e Professores & 15.01 .15 & Reunião online \\
\hline Gestores e Equipe Administrativa & 15.02 .15 & Reunião presencial \\
\hline \multicolumn{3}{|c|}{ CRONOGRAMA } \\
\hline Fase de Iniciação & \multicolumn{2}{|c|}{05.02 .15 a 05.04 .15} \\
\hline Fase de Planejamento & \multicolumn{2}{|c|}{05.03 .15 a 15.10 .15} \\
\hline Fase de Execução & \multicolumn{2}{|c|}{15.09 .15 a 15.12 .15} \\
\hline Fase de Monitoramento e Controle & \multicolumn{2}{|c|}{15.04 .15 a 15.01 .16} \\
\hline Fase de Encerramento & \multicolumn{2}{|c|}{15.12 .15 a 15.02 .16} \\
\hline \multicolumn{3}{|c|}{ ANÁLISE DE CUSTOS } \\
\hline Remuneração dos Tutores & \multicolumn{2}{|c|}{$\mathrm{R} \$ 1.800,00$} \\
\hline
\end{tabular}




\begin{tabular}{|l|c|}
\hline Encargos Administrativos & $\mathrm{R} \$ 360,00$ \\
\hline Remuneração do Design Gráfico & $\mathrm{R} \$ 5000,00$ \\
\hline Material gráfico & $\mathrm{R} \$ 540,00$ \\
\hline Recolhimento CEAP-EEUSP & $\mathrm{R} \$ 800,00$ \\
\hline Receitas de Inscrições & $\mathrm{R} \$ 10000,00$ \\
\hline
\end{tabular}

Fonte: A autora (2016)

Em seguida, o processo de orientação e gerenciamento do trabalho foi liderado pelas gestoras responsáveis. A dinâmica do projeto alcançou outro ritmo e os resultados começam a ser evidenciados. O "olhar" da equipe passou a ter 0 mesmo foco, porém com atenção ampliada aos detalhes. O efetivo gerenciamento do projeto requereu registros e disseminações de informação em tempo integral.

Duas abordagens, durante o processo de orientação e gerenciamento foram adotadas: uma baseada no registro das informações do trabalho que estava sendo desenvolvido pela equipe e outra referente aos aspectos dos cursistas, ou seja, informações se o objetivo do curso estava sendo evidenciado através das atividades iniciais. $\mathrm{O}$ equilíbrio destas duas abordagens caracterizou esta etapa do projeto.

No processo de monitoramento e controle do trabalho, as equipes monitoraram o progresso das aulas, a participação dos cursistas, o processo de comunicação entre cursistas e tutores, assim como a realização das atividades de aprendizagem solicitadas, visando manter o projeto em pleno andamento, conforme modelo no quadro 7. O controle integrado das mudanças gerenciou todas as demandas de dúvidas, dificuldades, solicitações de alterações.

Quadro 7. Modelo de Monitoramento por cursista de acordo com as atividades de aprendizagem do curso.

\begin{tabular}{|l|l|l|l|l|c|}
\hline \multicolumn{7}{|c|}{ UNIDADE DE APRENDIZAGEM 1 } \\
\hline Cursista & Data & $\begin{array}{l}\text { Atividade } \\
\text { realizada }\end{array}$ & $\begin{array}{l}\text { Participação do } \\
\text { Fórum/ Dúvidas }\end{array}$ & Feedback Fornecido & Tutor \\
\hline & & & & & \\
\hline & & & & & \\
\hline & & & & & \\
\hline & & & & & \\
\hline
\end{tabular}

Fonte: A autora (2016) 
Para este processo também foi elaborada uma planilha denominada "Memória de atividades" (Quadro 8), compartilhada entre a equipe do projeto de modo a viabilizar o preenchimento simultâneo do que cada integrante da equipe e cada cursista desenvolvia diariamente.

Quadro 8. Modelo de Memória de Atividades do Curso.

\begin{tabular}{|c|c|c|c|}
\hline \multicolumn{5}{|c|}{ MEMÓRIA DE ATIVIDADES } \\
\hline Data/horário & $\begin{array}{c}\text { Atividade } \\
\text { Desenvolvida }\end{array}$ & Local do AVA & $\begin{array}{c}\text { Integrante } \\
\text { responsável }\end{array}$ \\
\hline & & & \\
\hline & & & \\
\hline & & & \\
\hline & & & \\
\hline & & & \\
\hline
\end{tabular}

Fonte: A autora (2016)

No grupo do encerramento, a etapa contemplou a conclusão do curso e o fechamento de todas as suas ações. As análises sobre cada unidade de aprendizagem através da visão da equipe do projeto, o arquivamento de todos os registros construídos e divulgação das lições aprendidas por meio de reuniões ou publicações científicas, contemplaram este processo. Paralelamente, as parcerias e contratos profissionais também foram fechados.

O registro da avaliação do curso, por parte dos cursistas também foi armazenado. A avaliação do curso, por parte dos stackholders, foi realizada através de uma reunião coletiva e descrita através das produções científicas das pesquisadoras envolvidas. A importância deste registro deve-se ao fato da necessidade de reavaliação do projeto para formulação de mudanças e melhorias vislumbrando sua nova versão.

\subsubsection{GERENCIAMENTO DO ESCOPO DO PROJETO}

Os processos de gerenciamento do escopo se concentram nos grupos de planejamento e Monitoramento e Controle conforme ilustra o Mapa Mental a seguir (Figura 13): 
Figura 13. Mapa Mental dos processos e ações envolvidas no Gerenciamento do Escopo.

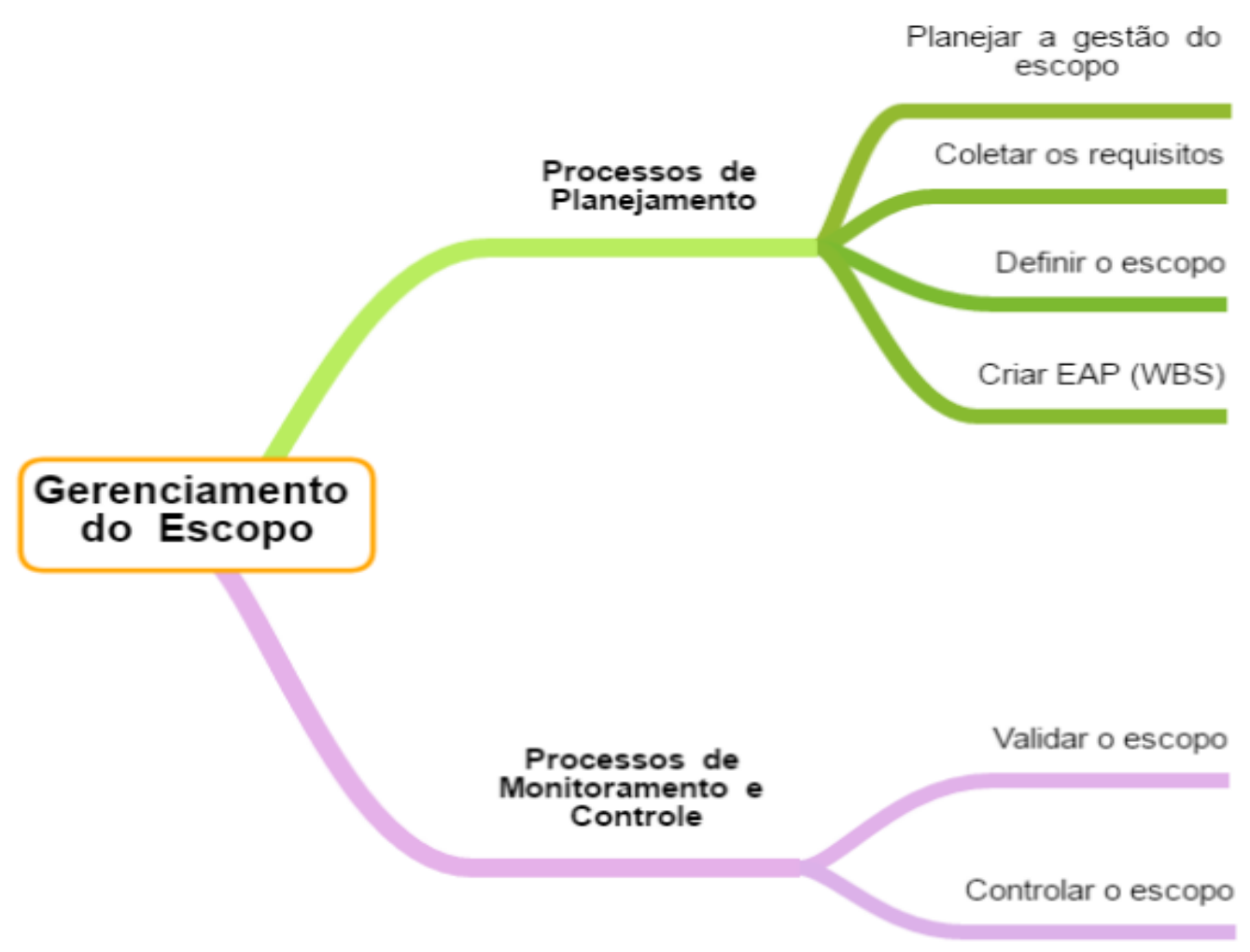

Fonte: A autora (2016).

O processo de planejar o gerenciamento do escopo teve o objetivo de elaborar o plano que documentou como seria definido, validado e controlado o escopo, contemplando a justificativa de criação do curso, a metodologia adotada, os procedimentos e documentos iniciais para liberação do projeto do curso, como seria realizado o gerenciamento e por qual integrante da equipe, assim como a execução, o monitoramento e controle do cronograma do projeto e a estruturação e organização da Estrutura Analítica do Projeto (EAP).

O processo de coletar os requisitos envolveu um brainstorming, observações e técnicas de tomada de decisão em grupo com os stackeholders acerca das demandas profissionais voltadas as necessidades dos cursistas e da própria equipe no intuito de criar produções científicas nesta área de atuação. Também foi considerado um protótipo de um planejamento de curso anteriormente realizado por três integrantes da equipe.

A definição do escopo focou o acréscimo de uma descrição detalhada do que seria desenvolvido no curso para ser entregue aos cursistas como produto, titulada pedagogicamente pela equipe de "Matriz de design instrucional geral" e 
inserida no plano de gerenciamento do projeto, juntamente com a Matriz de responsabilidades da equipe, o cronograma de reuniões e o cronograma das fases.

A criação da EAP, também conhecida como Work Breackdown Structure (WBS) formulou, através de uma representação hierárquica, o processo de divisão do projeto, por fases e produtos, ou seja, unidades de aprendizagem e equipes, componentes menores e mais facilmente gerenciáveis.

Figura 14. Mapa Mental dos processos e ações envolvidas na Estrutura Analítica do Projeto

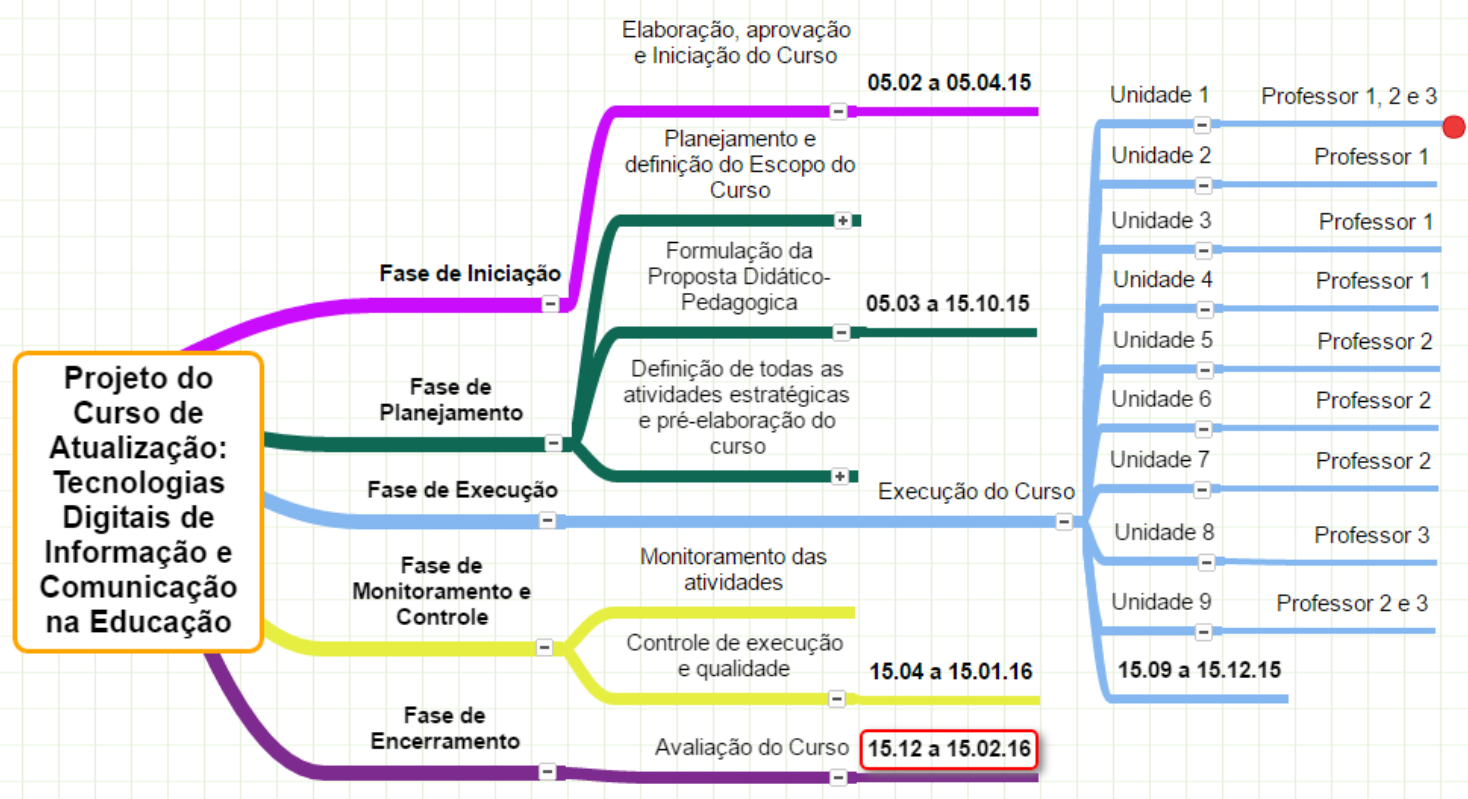

Fonte: A autora (2016).

A EAP pode ser estruturada como uma lista resumida, tabela, um gráfico organizacional ou outro método que identifique uma decomposição hierárquica, como o Mapa Mental da Figura 14. Pesquisas em gerenciamentos de projetos tem debatido com relação as regras de decomposição, todavia não chegaram a um consenso de até que nível devem desagregar os elementos de uma EAP mas apenas que a estrutura apresente uma visão geral do projeto e associe responsabilidades aos envolvidos.

A validação e o controle do escopo tiveram como objetivo a formalização do curso e o monitoramento periódico do andamento do escopo com intuito de inspecionar a entrega de todos os componentes aos cursistas, dentro do prazo estabelecido e com os parâmetros de qualidade pré-determinados. Baseando-se 
no plano de gerenciamento do curso, foi realizado um checklist das ações por unidade de aprendizagem.

O escopo do projeto foi validado no dia seguinte do termino da ultima tarefa da fase, onde foi analisado se todos os critérios de aceitação foram atingidos e os possíveis desvios. O principal benefício deste método, de acordo com o PMBOK (2013) é que ele proporciona objetividade ao processo de aceitação e aumenta a probabilidade da aceitação final do produto, serviço ou resultado, através da validação de cada entrega.

A análise final desta etapa, mirando o desempenho do escopo resultou numa solicitação de mudança da linha de base do escopo e de outros componentes do plano de gerenciamento do projeto. As solicitações de mudança incluíram solicitações de aprimoramento nas próximas versões do curso, como por exemplo, atenção especial aos materiais de áudio e vídeo, com legenda, para portadores de deficiência auditiva e ampliação dos prazos de entregas de algumas atividades avaliativas.

\subsubsection{GERENCIAMENTO DO TEMPO DO PROJETO}

O gerenciamento do tempo do projeto inclui os processos necessários para gerenciar o término pontual do projeto. Em alguns projetos, especialmente naqueles de escopo menor, os processos de definir as atividades, sequenciar as atividades, estimar os recursos e as durações das atividades e desenvolver o modelo do cronograma estão tão estreitamente conectados que são vistos como um único processo.

O Mapa Mental apresentado na figura 15, fornece uma visão geral dos processos de gerenciamento do tempo do projeto, que são: 
Figura 15. Mapa Mental dos Processos de Gerenciamento do Tempo distribuídos ao longo das fases do projeto.

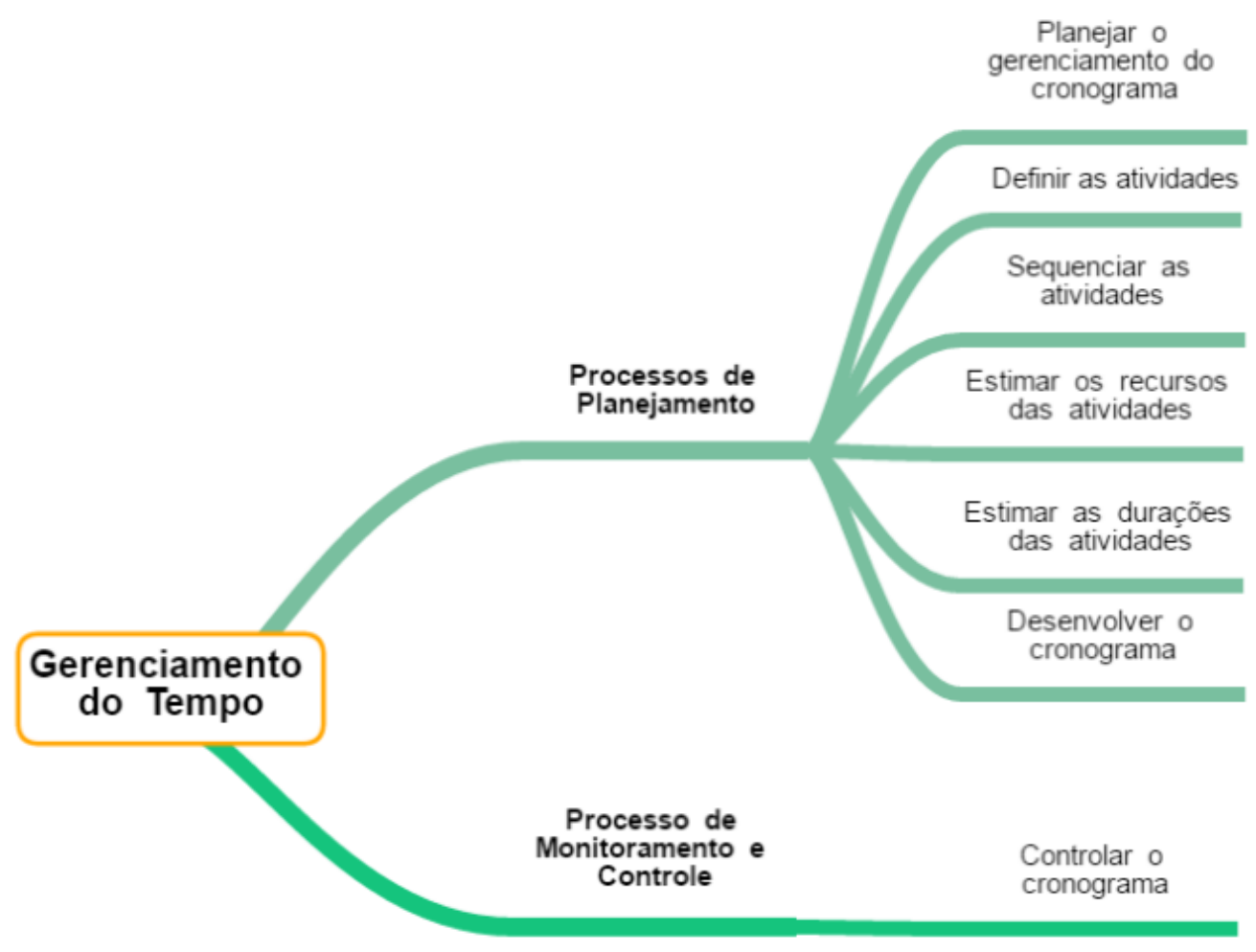

Fonte: A autora (2016).

Como o projeto do curso foi contínuo, interligado e sequenciado, apesar da flexibilidade dos cursistas em navegar no ambiente virtual de aprendizagem de forma autônoma entre as unidades, a equipe do projeto decidiu desenvolver 0 gerenciamento do cronograma integrando todas as etapas do processo de planejamento em um único documento, conforme quadro 9.

O plano de gerenciamento do cronograma do curso foi definido pelas atividades sequenciais, das fases e da lista de atividades, definindo além dos períodos por unidade de aprendizagem, o professor gestor responsável pela elaboração das aulas. Também foi formado um cronograma de reuniões, contemplando a equipe por encontro, data e modo de comunicação. Como os recursos não puderam ser mensurados por período, foi elaborado uma lista de recursos das atividades gerais para posterior controle de cronograma de pagamentos e prestação de contas. 
Quadro 9. Plano de gerenciamento do cronograma do curso.

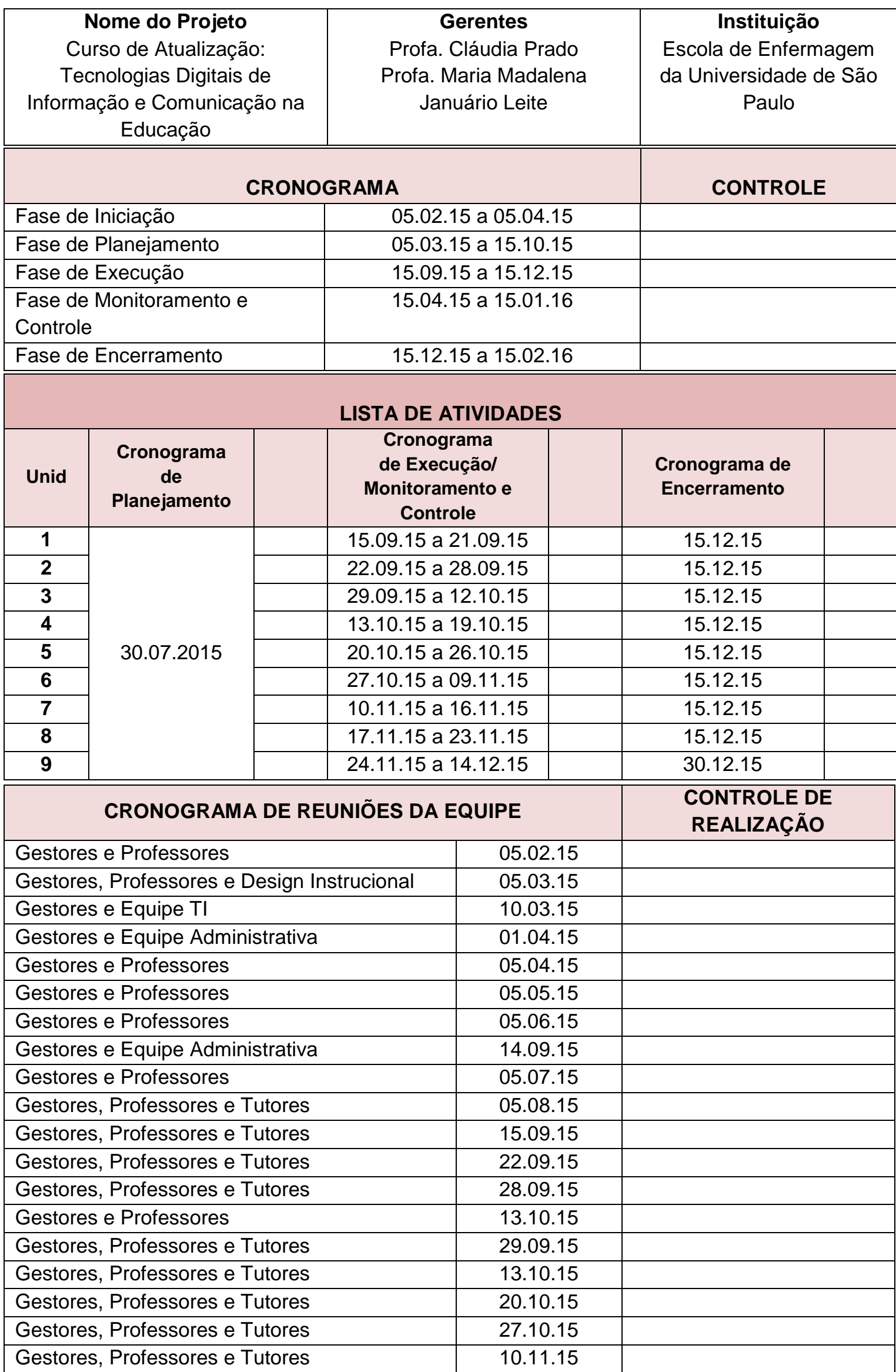




\begin{tabular}{|l|l|l|}
\hline Gestores, Professores e Tutores & 17.11 .15 & \\
\hline Gestores, Professores e Tutores & 25.11 .15 & \\
\hline Gestores, Professores e Tutores & 21.12 .15 & \\
\hline Gestores e Professores & 15.01 .15 & \\
\hline Gestores e Equipe Administrativa & 15.02 .15 & \\
\hline
\end{tabular}

\begin{tabular}{|l|c|c|}
\hline \multicolumn{2}{|c|}{ RECURSOS DAS ATIVIDADES } & $\begin{array}{c}\text { CONTROLE DE } \\
\text { PAGTOS }\end{array}$ \\
\hline Remuneração dos Tutores & $\mathrm{R} \$ 1.800,00$ & \\
\hline Encargos Administrativos & $\mathrm{R} \$ 360,00$ & \\
\hline Remuneração do Design Gráfico & $\mathrm{R} \$ 5000,00$ & \\
\hline Material gráfico & $\mathrm{R} \$ 540,00$ & \\
\hline Recolhimento CEAP-EEUSP & $\mathrm{R} \$ 800,00$ & \\
\hline Receitas de Inscrições & $\mathrm{R} \$ 10000,00$ & \\
\hline
\end{tabular}

\begin{tabular}{|l|l|l|}
\hline \multicolumn{2}{|c|}{ RECURSOS HUMANOS } & NOME \\
\hline Gestores do Projeto & 02 & \\
\hline $\begin{array}{l}\text { Coordenadores de Unidades de } \\
\text { Aprendizagem/Conteúdistas }\end{array}$ & 03 & \\
\hline Tutores/Motivadores & 02 & \\
\hline Analistas de Suporte Técnico & 02 & \\
\hline Designer Instrucional & 01 & \\
\hline
\end{tabular}

Fonte: A autora (2016)

O cronograma aprovado foi a linha de base usada no processo de gerenciamento do tempo. À medida que as atividades foram desenvolvidas, a maior parte do esforço na área de conhecimento de gerenciamento do tempo do projeto ocorreu na busca de assegurar o término pontual destas atividades. 0 processo de monitoramento e controle do cronograma foi efetivado através de um checklist e compartilhado no Google Docs para acesso participativo as informações temporais das atividades. Esse compartilhamento teve por benefício trazer a correta compreensão dos "tempos" de cada processo pelos gestores e demais membros da equipe.

Uma das dificuldades no gerenciamento do tempo de um projeto educacional é a capacidade de estimar as durações das ações, ou seja, o tempo de trabalho que será necessário para terminar as atividades específicas, seja por parte dos professores, na elaboração das aulas, seja por parte do cursistas, na conclusão dos conteúdos.

A estimativa das durações das atividades utilizou um cálculo aproximado baseado informações do escopo do trabalho, os recursos tecnológicos e 
metodologias de aprendizagem, o calendário e a experiência dos gestores, professores e tutores na preparação de planos de aula e realização de cursos a distância. Outro recurso utilizado foi a simulação, que envolveu cálculos de horas e possibilitou obter uma estimativa média de tempo para completar a atividade.

O PMBOK discrimina a existência de várias técnicas mais complexas para o desenvolvimento e o controle do cronograma, todavia não se fez necessária a aplicabilidade das mesmas, haja vista a característica do projeto deste curso.

\subsubsection{GERENCIAMENTO DOS CUSTOS DO PROJETO}

O gerenciamento dos custos do projeto inclui os processos envolvidos em planejamento, estimativas, orçamentos, financiamentos, gerenciamento e controle dos custos, de modo que o projeto possa ser terminado dentro do orçamento aprovado. Os processos de gerenciamento dos custos se dividem de acordo com o Mapa Mental a seguir (Figura 16):

Figura 16. Mapa Mental dos processos e ações envolvidas no Gerenciamento de Custos.

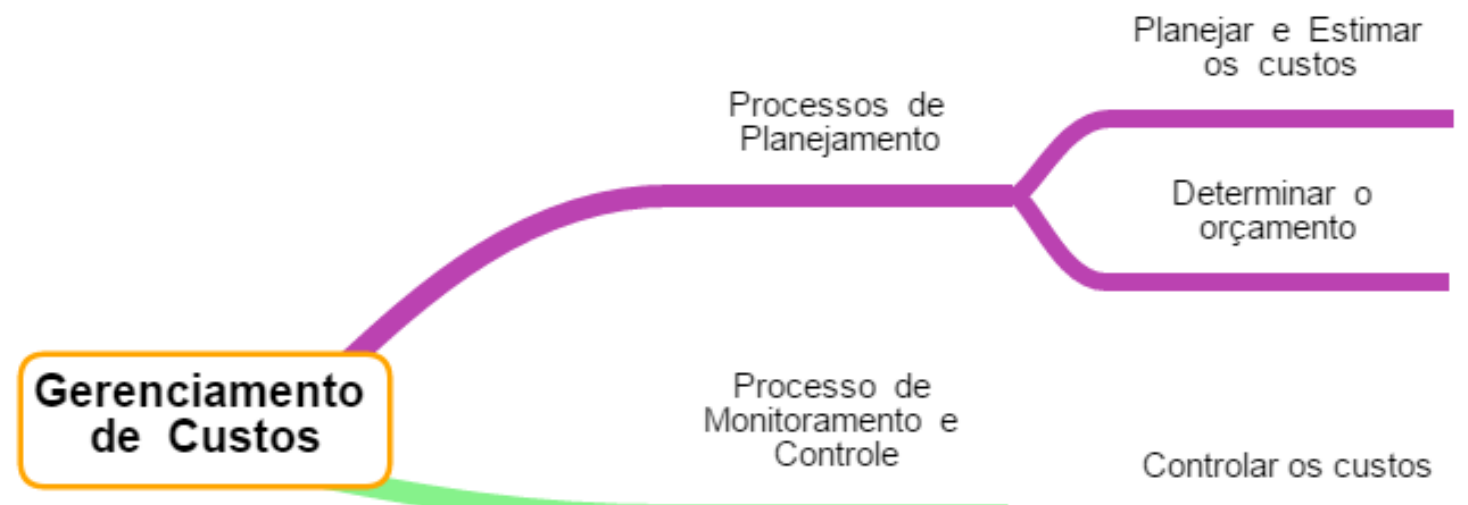

Fonte: A autora (2016)

A etapa de planejamento e estimativa de custos do projeto considerou os recursos humanos (gestores, professores, tutores, equipe administrativa e de $\mathrm{TI}$, design gráfico), os recursos tecnológicos e equipamentos, os materiais de divulgação do curso, encargos administrativos, impostos e os recursos financeiros gerados pelas matrículas dos cursistas. 
Algumas vantagens que geraram um baixo custo na elaboração do curso foi o fato de se ter utilizado como parte dos recursos humanos, tecnológicos e equipamentos, a equipe de profissionais vinculada a Escola de Enfermagem da USP e a infraestrutura da universidade. Os gastos ficaram exclusivamente vinculados a contratação dos tutores, do serviço especializado de design gráfico, os encargos administrativos e impostos definidos pelas diretrizes existentes na instituição proponente.

As estimativas e o controle dos custos incluíram a identificação e a consideração dos custos para iniciar e terminar o projeto. Compensações de custos e riscos foram consideradas, tais como fazer a contratação de mais tutores de acordo com o número de cursistas matriculados. Também foi considerada uma estimativa por analogia, ponderando a experiência anterior das gestoras na implantação de projetos similares na mesma instituição e o fluxo de caixa mínimo necessário para viabilizar o plano.

O uso de tabelas e planilhas auxiliou este processo apresentando o orçamento final baseado nas despesas e receitas geradas, não constituindo necessariamente um padrão a ser seguido. A tabela de análise dos custos foi documentada no Plano de Gerenciamento do Projeto e vinculada ao termo de abertura do projeto.

O gerenciamento dos custos do projeto considerou os requisitos das partes interessadas devido ao fato que ambas mediram os custos do projeto de maneiras diferentes em tempos diferentes. Qual o custo de um projeto educacional (valor planejado)? Qual o custo de investimento de um curso de aperfeiçoamento profissional (valor agregado)? Estas são perguntas que permeiam as partes interessadas e devem ser consideradas no planejamento.

Aplicativos de software para o gerenciamento de projetos, planilhas computadorizadas, simulações e ferramentas estatísticas podem ser usados para ajudar nas estimativas de custos, de acordo com o PMBOK, entretanto como o projeto ficou vinculado a uma instituição de ensino de caráter público, com diretrizes de orçamento pré-determinadas, não se fez cogente. 


\subsubsection{GERENCIAMENTO DA QUALIDADE DO PROJETO}

O gerenciamento da qualidade do projeto inclui processos e as atividades que determinam as políticas de qualidade, os objetivos e as responsabilidades, de modo que a garantir que os requisitos do projeto, incluindo os requisitos do produto, sejam cumpridos e validados. Os processos de gerenciamento da qualidade são exibidos através do Mapa Mental a seguir (Figura 17):

Figura 17. Mapa Mental dos processos e ações envolvidas no Gerenciamento da Qualidade.

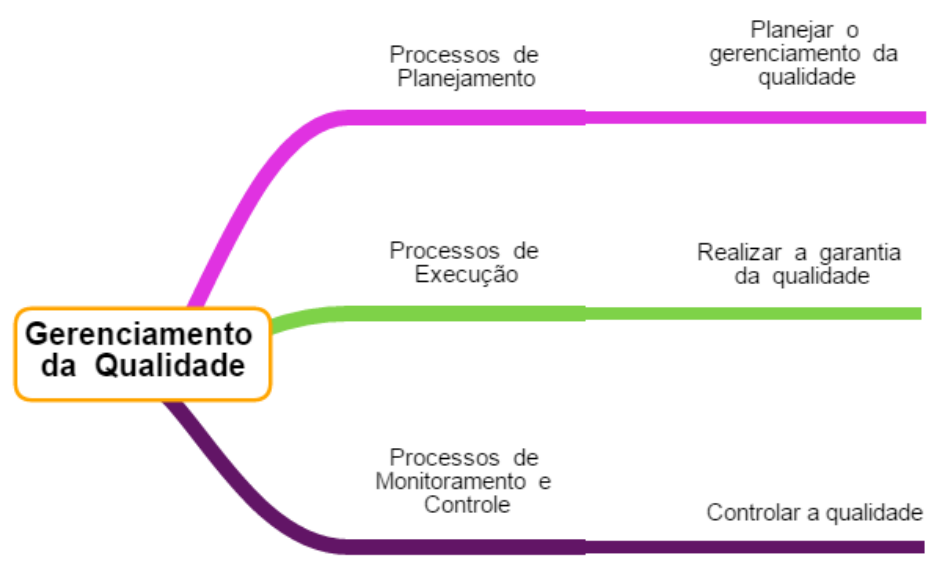

Fonte: A autora (2016)

A etapa de planejamento do gerenciamento da qualidade visou a identificação dos padrões da qualidade do projeto definidos pela equipe gestora, caracterizando-se por um plano de gerenciamento do projeto bem estruturado; a escolha do ambiente virtual de aprendizagem, o Moodle; os objetivos do curso definidos unidade a unidade e apresentados sempre no início das atividades; a equipe de gerenciamento do projeto, composta por docentes com ampla experiência em gerenciamento, ensino superior, cursos de EAD e na qualificação docente.

Essa etapa também considerou os pré-requisitos mínimos para participação dos cursistas vinculadas a formação de base e da acessibilidade dos programas virtuais; a satisfação dos mesmos ao término do curso, evidenciada por meio de questionamentos individuais; o cronograma, estruturado no plano inicial; o design instrucional para geração do material didático baseado na concepção de ensino; o 
emprego do PMBOK como ferramenta gerencial, os custos operacionais, dentre outros.

Através da técnica de brainstorming as ideias dos membros da equipe do projeto foram analisadas pelos gerentes do projeto. $\mathrm{O}$ objetivo mais visado pela equipe do projeto, no eixo gerenciamento de qualidade foi o de assegurar a conclusão do curso dentro da qualidade esperada, garantindo assim a satisfação das necessidades de todos os envolvidos e a atualização dos documentos do projeto para as versões subsequentes do curso.

O modo de garantir a qualidade foi evidenciado pela análise do processo e redefinições operacionais pelos gestores. O controle da qualidade foi obtido para avaliar o desempenho da equipe e dos cursistas, visando mudanças e melhorias no planejamento, gerenciamento e efetividade do curso.

\subsubsection{GERENCIAMENTO DOS RECURSOS HUMANOS}

A equipe do projeto consiste das pessoas com papéis e responsabilidades designadas para completar o projeto. Os membros da equipe do projeto podem ter vários conjuntos de habilidades, atuar em regime de tempo integral ou parcial, e podem ser acrescentados ou removidos da equipe à medida que o projeto progride. O Mapa Mental seguinte (Figura 18) exibe uma visão geral dos processos de gerenciamento dos recursos humanos do projeto: 
Figura 18. Mapa Mental dos processos e ações envolvidas no Gerenciamento dos Recursos Humanos.

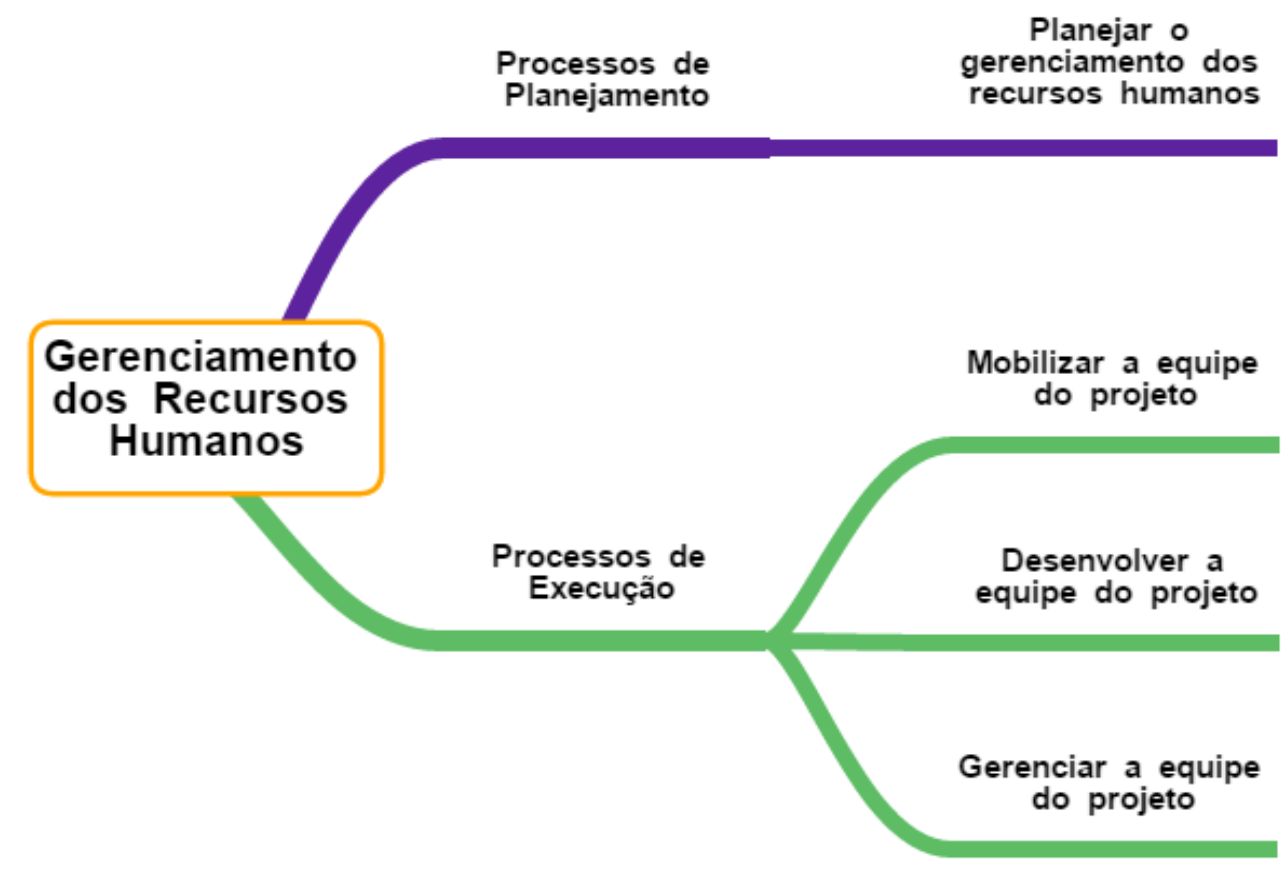

Fonte: A autora (2016).

O planejamento do gerenciamento dos recursos humanos conteve a identificação de papéis, responsabilidades e aptidões necessárias para formação de uma equipe multidisciplinar experiente em EAD e educação coorporativa com uma visão sistêmica das etapas do projeto. Todos os resultados do projeto podem ser vistos como fruto das relações humanas e das habilidades interpessoais dos envolvidos.

O plano de gerenciamento do pessoal foi baseado no plano de gerenciamento do curso e no plano de gerenciamento do cronograma. Apesar de não ter sido elaborado um plano específico de recursos humanos, o objetivo foi garantir que cada pacote de trabalho tivesse um responsável definido, e que todos os membros da equipe compreendessem claramente seus papéis e responsabilidades.

O processo de confirmação da disponibilidade dos recursos humanos, ou seja, a mobilização da equipe necessária para terminar as atividades do projeto, exigiu um conjunto de profissionais composto por perfis distintos, como gestores, professores, tutores, design instrucional, secretários e auxiliares administrativos, 
todos vinculados a Universidade de São Paulo, mais especificamente ao Departamento de Orientação Profissional da Escola de Enfermagem .

Esta opção seletiva garantiu um nicho de profissionais já alocados na instituição proponente, com atendimento imediato as demandas do projeto e um menor custo financeiro. Depois que os membros da equipe inicial criaram uma estrutura analítica do projeto, foi necessário mobilizar pessoal adicional para a equipe visando um atendimento aos cursistas mais veloz e eficaz, sem afetar os cronogramas e orçamentos ou a qualidade e os riscos. Deste modo a equipe foi subdividida em:

- Gestores do Projeto

- Coordenadores de Unidades de Aprendizagem/Conteúdistas

- Tutores/Motivadores

- Analistas de Suporte Técnico

- Designer Instrucional

O desenvolvimento da equipe do projeto visou o processo de melhoria de competências, da interação da equipe e do ambiente geral para aperfeiçoar o desempenho do projeto. Alguns integrantes realizaram cursos de especialização visando o aprimoramento profissional, outros ampliaram suas pesquisas científicas para garantir o objetivo do projeto e todos realizaram reuniões de integração e reconhecimento das metas, individuais e coletivas, visando aprimorar os sentimentos de confiança e consenso entre os membros da equipe.

O gerenciamento da equipe do projeto visou o acompanhamento dos membros da equipe, o fornecimento de feedback, a resolução de problemas e o gerenciamento de possíveis mudanças para otimizar o desempenho do projeto. Esta etapa foi efetivada através de observações e reuniões. Essas reuniões influenciaram a combinação de outras ferramentas que permitiram que todos os membros da equipe de gerenciamento cheguem a um consenso sobre o projeto.

\subsubsection{GERENCIAMENTO DAS COMUNICAÇÕES DO PROJETO}

O gerenciamento das comunicações do projeto inclui os processos necessários para assegurar que as informações do projeto sejam planejadas, 
coletadas, criadas, distribuídas, armazenadas, recuperadas, gerenciadas, controladas, monitoradas e finalmente dispostas de maneira oportuna e apropriada. Os processos de gerenciamento das comunicações se reúnem nos grupos de planejamento, execução, monitoramento e controle conforme delineia o Mapa Mental a seguir (Figura 19):

Figura 19. Mapa Mental dos processos e ações envolvidas no Gerenciamento das Comunicações.

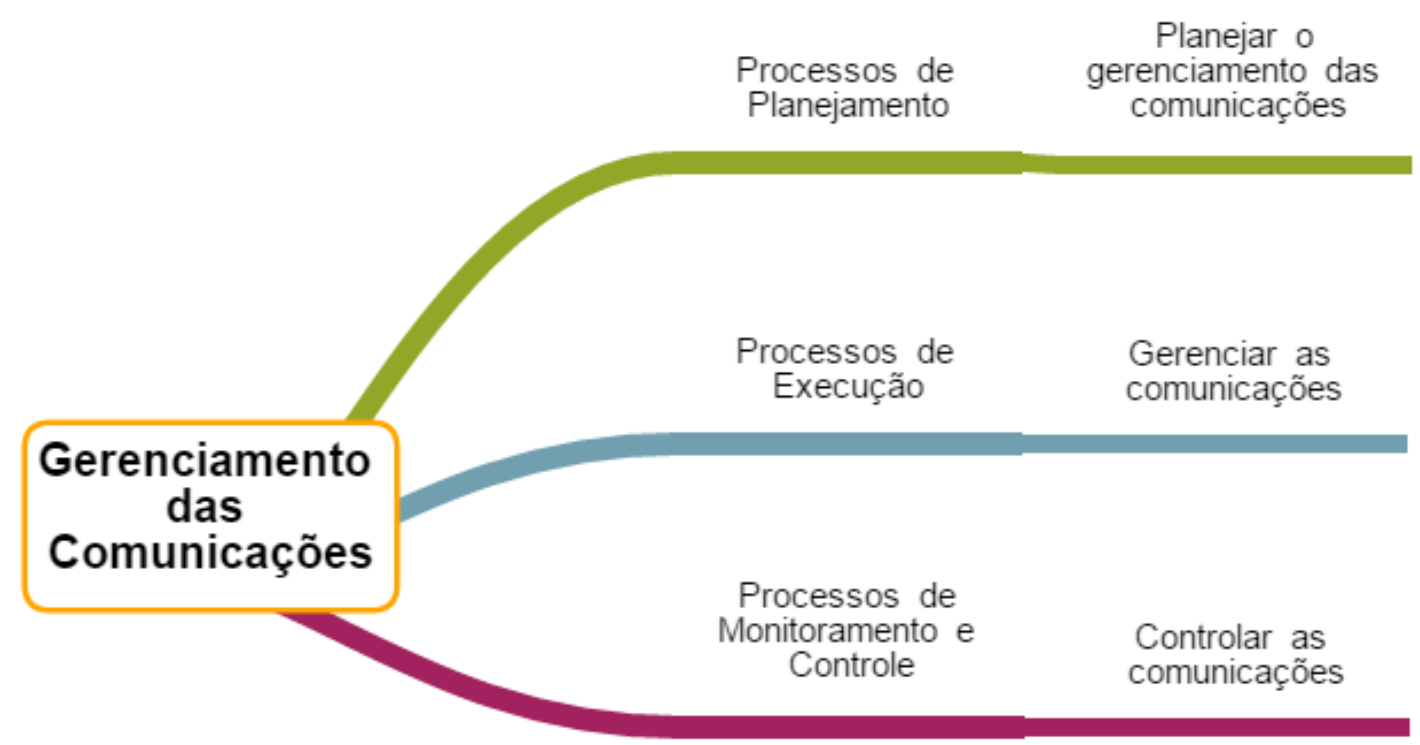

Fonte: A autora (2016).

O planejamento do gerenciamento das comunicações visou desenvolver uma abordagem apropriada e um plano de comunicações do projeto com base nas necessidades de informação e requisitos das partes interessadas. Foi definida quais as informações que cada parte interessada deveria receber, incluindo formato, conteúdo e nível de detalhamento, meio midiático, frequência e controle de envio.

O gerenciamento das comunicações criou, coletou, distribuiu e armazenou as informações do projeto (curso) baseando-se nas tecnologias das comunicações, ou seja, na internet, email, Skype, hangout, WhatsApp e no ambiente virtual de aprendizagem e suas ferramentas síncronas e assíncronas, como chat, fórum, blog, wiki, biblioteca virtual, glossário e mesmo o facebook. Foi necessário assegurar que a tecnologia requerida para facilitar a comunicação 
fosse compatível e estivesse disponível por todas as partes interessadas durante todo o ciclo de vida do projeto.

Outras formas de comunicação foram envolvidas nesse projeto, incluindo: comunicação interna (entre a equipe do projeto) e externa (cursistas, instituição, parceiros); comunicação formal (relatórios, minutas, instruções) e informal (discussões ad hoc); comunicação vertical (nos níveis superiores e inferiores da instituição proponente) e horizontal (com colegas); comunicações oficiais (divulgação do curso, boletins informativos, relatórios) e não oficiais (comunicações confidenciais); e comunicação escrita e oral, e verbal (inflexões da voz) e não verbal (linguagem corporal).

Um desafio encontrado para estabelecer uma comunicação eficaz com as partes interessadas do projeto foi a existência de um dos cursistas portador de deficiência auditiva. Tal contexto somente foi evidenciado após a necessidade do mesmo de compreender um dos vídeos armazenados na biblioteca virtual. A equipe realizou a transcrição do áudio e retificou o arquivo para os projetos subsequentes, traçando mudanças no plano de gerenciamento.

A partir deste contexto, o controle das comunicações tendeu a ampliar o monitoramento das transmissões e diálogos no decorrer de todo o ciclo de vida do projeto para assegurar que as necessidades de informação das partes interessadas fossem atendidas dentro de um intervalo mínimo de tempo por um grupo responsável pela comunicação da informação.

\subsubsection{GERENCIAMENTO DOS RISCOS DO PROJETO}

O Gerenciamento dos riscos do projeto inclui os processos de planejamento, identificação, análise, planejamento de respostas e controle de riscos de um projeto. Os processos de gerenciamento dos riscos são exibidos no próximo Mapa Mental (Figura 20): 
Figura 20. Mapa Mental dos processos e ações envolvidas no Gerenciamento de Riscos.

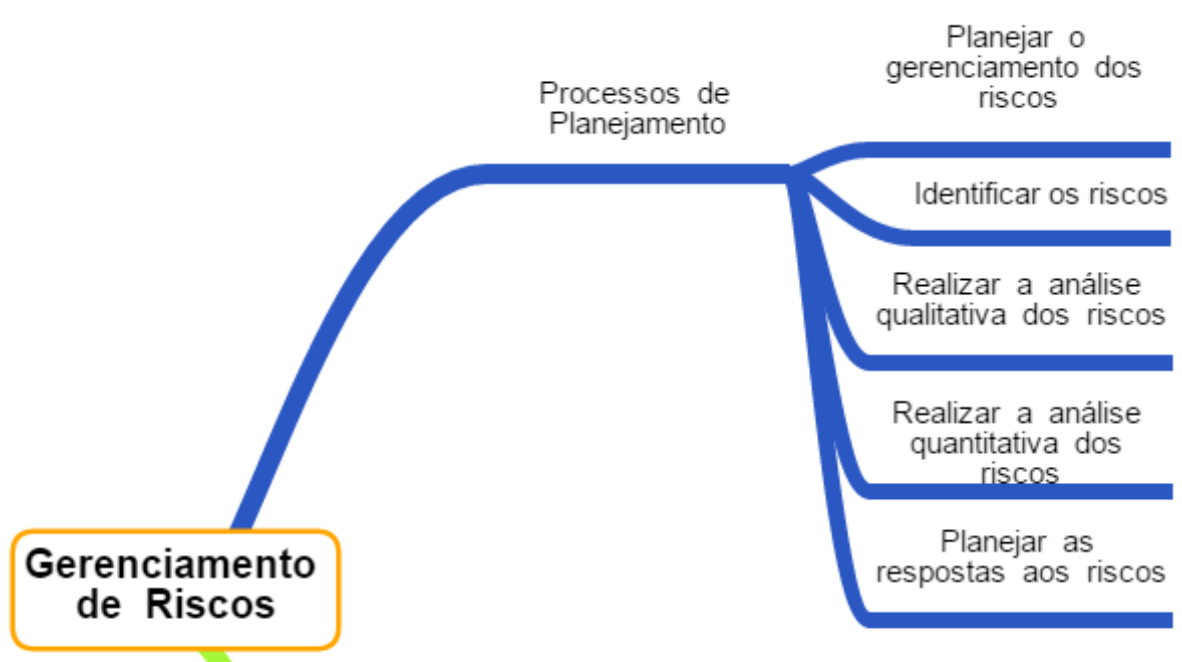

Processos de Controle Controlar os riscos

Fonte: A autora (2016).

Durante esta etapa do projeto, os seguintes questionamentos foram cruciais para suscitar os possíveis riscos existentes: qual a equipe deve integrar este projeto? como organizá-la? qual metodologia e a teoria mais adequada? como dimensionar a carga horária? Teremos tempo e dinheiro para prover o curso? as ferramentas escolhidas serão apropriadas? as metas e recursos são reais? quantos cursistas podem ser inscritos? quanto deve ser cobrado pelo curso? quais as ameaças e oportunidades de êxito?

Os riscos evidenciados em projetos educacionais a distância estão geralmente vinculados a ausência de critérios de concepção, viabilidade e avaliação dos projetos, problemas de integração entre as partes envolvidas, qualificação dos profissionais e gestores do projeto, desistência dos cursistas, dificuldade de operacionalização dos sistemas tecnológicos, custos e prazos.

Ciente destes riscos, já identificados em estudos acadêmicos, este projeto educacional analisou e planejou as respostas através de técnicas de Brainstorming e listas de verificação, de forma simplificada, evitando desta forma, problemas relacionados a qualidade, custos e cronograma, com antecedência. 
Assim, o gerenciamento dos riscos ocorreu de forma pró-ativa (e não reativa), analisando, monitorando e controlando ações que conduziram eventos favoráveis.

A análise qualitativa dos riscos avaliou a severidade e a significância dos mesmos, baseando-se no grau de impacto no projeto e a possibilidade concreta que os riscos ocorressem. A análise quantitativa vislumbrou a possibilidade de algum risco inviabilizar a obtenção das metas do projeto, através de opiniões de especialistas com experiência em projetos educacionais.

A estratégia de evitar os riscos, de forma a adaptar o plano do projeto para eliminar as causas dos riscos foi a escolhida pelas gerentes do projeto. As gerentes comprometeram a equipe em relação as suas responsabilidades face a gestão de riscos, bem como os efeitos imprevistos e qualquer correção necessária.

A seleção de uma equipe qualificada e integrada, experiente em EAD e formação docente, os custos de contratação minimizados, a escolha de um ambiente virtual mundialmente reconhecido e uma instituição proponente respeitada no cenário educacional, além de um cronograma amplamente planejado, aproximaram os riscos a próximos de zero, refletindo o equilíbrio entendido pelos gerentes do projeto entre correr riscos e evitar riscos.

A evasão de $25 \%$ dos cursistas foi um dos riscos gerenciados e confirmados durante o projeto, porém que corroborou em termos quantitativos com o Censo de Educação da Distância no Brasil de 2015, que registrou um percentual de $40 \%$ das instituições que ofereceram cursos regulamentados totalmente a distância apresentou uma evasão de $26 \%-50 \%$. Ao mesmo tempo, $31,71 \%$ das instituições que ofereceram cursos livres não corporativos apresentaram evasão na faixa de $26 \%-50 \%$, situação compartilhada por $26,15 \%$ dos estabelecimentos que ofereceram cursos corporativos.

Este conjunto de ações executadas pelo gerente do projeto de forma a maximizar os efeitos dos riscos positivos (oportunidades) e minimizar os efeitos dos riscos negativos (ameaças), em outros projetos mais complexos e que demandam níveis de controle de recursos mais detalhados, tendem a ter mais incertezas e consequentemente exigem um gerenciamento de riscos mais amplo, minucioso e com uma análise de probabilidade de riscos durante todos os ciclos devida do projeto, com base na avaliação da sua probabilidade e impacto. 


\subsubsection{GERENCIAMENTO DAS AQUISIÇÕES DO PROJETO}

O gerenciamento das aquisições do projeto inclui os processos necessários para comprar ou adquirir produtos, serviços ou resultados externos à equipe do projeto. Os processos de gerenciamento das aquisições se decompõem conforme o Mapa Mental a seguir (Figura 21):

Figura 21. Mapa Mental dos processos e ações envolvidas no Gerenciamento das Aquisições.

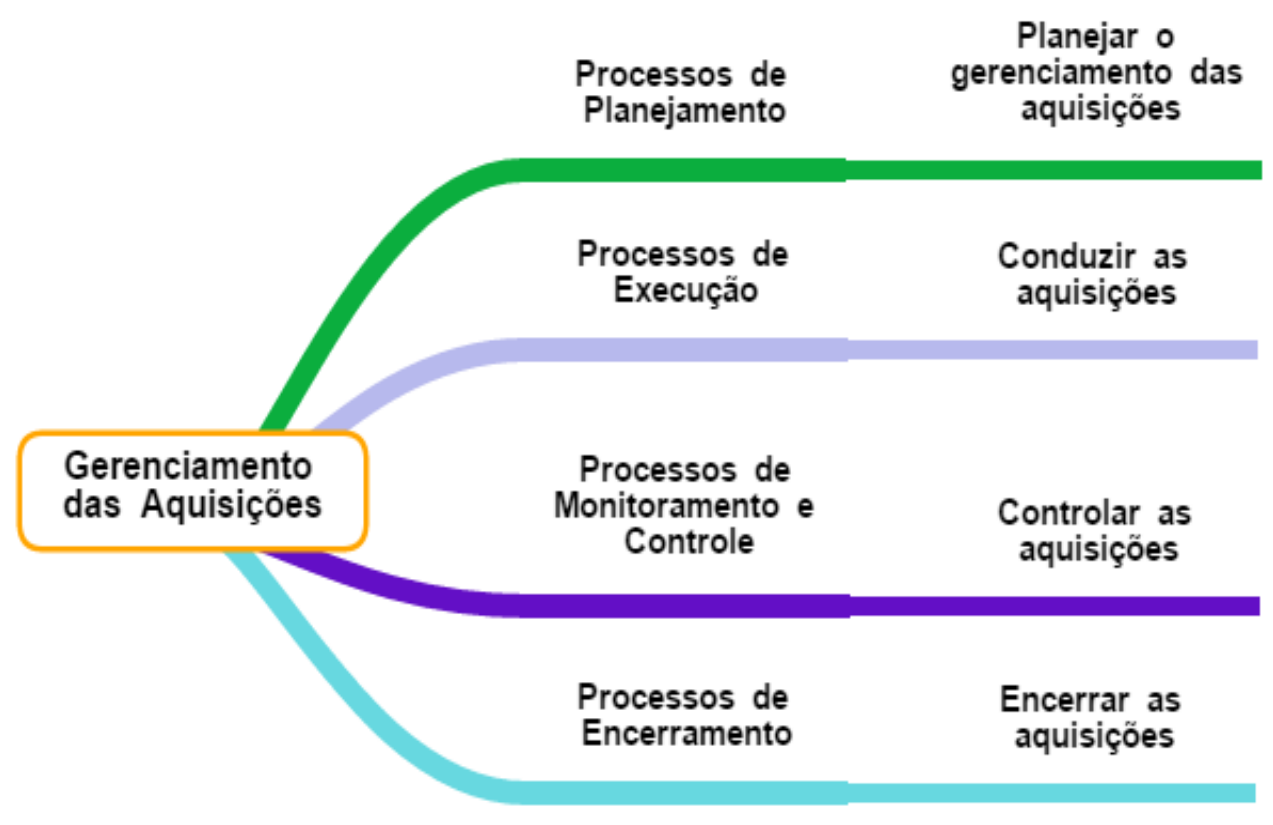

Fonte: A autora (2016).

O gerenciamento das aquisições incluiu os processos de garantia de bens e serviços necessários ao desenvolvimento deste projeto. O planejamento das aquisições foi estabelecido através da identificação de demandas de produtos e recursos humanos durante o plano de gerenciamento. Optou-se por terceirizar serviços muito especializados que não estavam diretamente ligados as competências e habilidades dos membros da equipe do projeto e também a disponibilidade de tempo para efetivação do cronograma, como serviços gráficos de arte e impressão, de tutores e desing gráfico.

A condução das aquisições foi realizada pelas gerentes do projeto após indicação técnica das partes interessadas e especialistas da área. A adjudicação do contrato foi realizada, considerando valores, prazos e qualidade do serviço em consonância com o objetivo do projeto. As aquisições foram realizadas com os 
prestadores de serviço através de contratos por preço fixo e especificação do trabalho antes do início do curso e o encerramento das mesmas findou-se após a entrega e pagamento dos bens e serviços, com seus devidos impostos e encargos administrativos.

As aquisições sem custos foram realizadas diretamente com os colaboradores vinculados a instituição proponente, envolvendo a prestação de serviços administrativos e de informática.

\subsubsection{GERENCIAMENTO DAS PARTES INTERESSADAS DO PROJETO}

O gerenciamento das partes interessadas (stakeholders) do projeto inclui os processos exigidos para identificar as pessoas, grupos ou organizações que podem impactar ou serem impactados pelo projeto, analisar as suas expectativas e desenvolver estratégias apropriadas para o engajamento eficaz das partes nas decisões e execução do projeto. O Mapa Mental descrito na figura 22, provê um painel dos processos de gerenciamento das partes interessadas, que são:

Figura 22. Mapa Mental dos processos e ações envolvidas no Gerenciamento das Partes Interessadas.

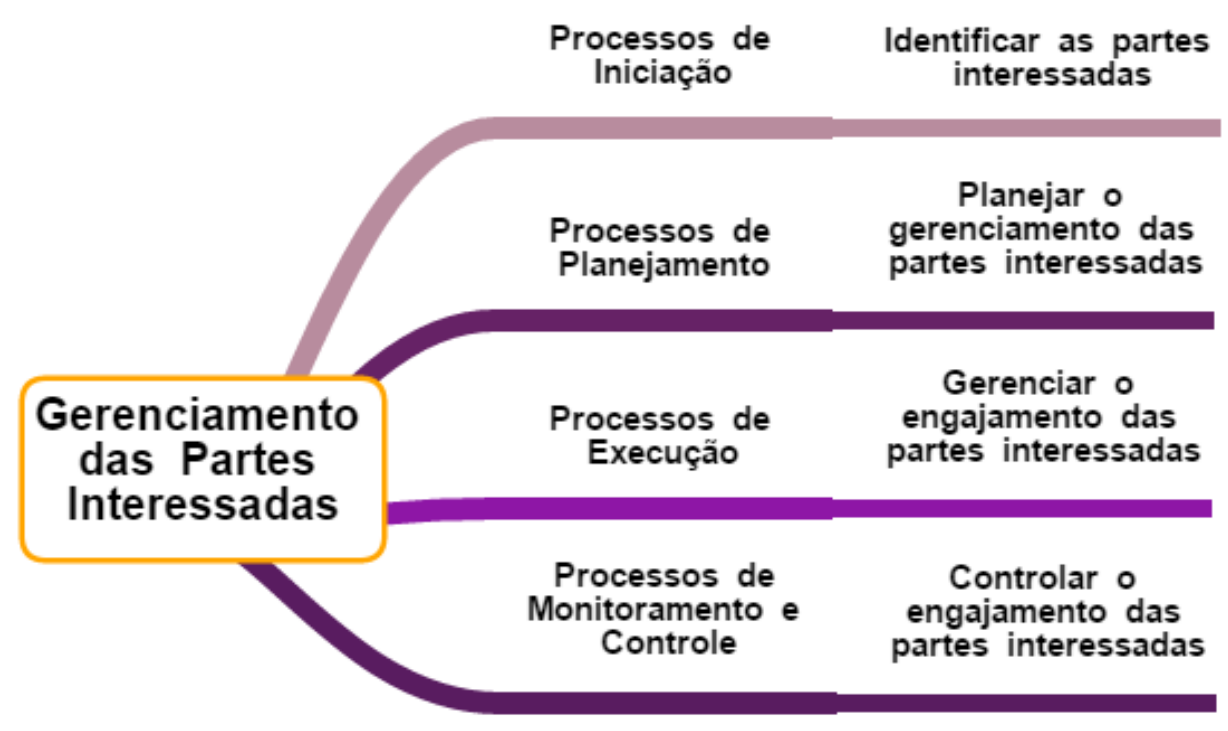

Fonte: A autora (2016).

Identificar os stakeholders no processo foi a primeira etapa deste projeto e uma das principais preocupações dos gerentes, pois geralmente as partes 
interessadas possuem expectativas distintas. Existiram dois grupos neste gerenciamento do projeto educacional: os interessados primários, ou seja, a equipe idealizadora e executora do projeto, formada pelos gestores e demais membros, e os interessados secundários, que composta pelos cursistas, beneficiários diretos pelo êxito do empreendimento.

Os interessados primários formaram uma equipe composta por docentes, doutorandos, mestrandos e funcionários da Universidade de São Paulo. Os secundários constituíram um grupo de profissionais interessados em cultivar conhecimentos acerca do uso de TDIC como recursos pedagógicos na educação através da EAD.

A identificação das partes interessadas secundárias, tratando-se de projetos educacionais, permeou todos os ciclos de vida do projeto considerando que desde a inscrição no curso até sua finalização, as informações pessoais, profissionais e de conhecimento científico dos cursistas foram agregadas continuamente.

Uma vez identificados os interessados, foi necessário gerar um registro completo dos indivíduos, com seus respectivos interesses, incluindo uma avaliação preliminar de cada um que serviu de base de planejamento. $O$ plano de gestão foi composto por uma lista dos stakeholders, contemplando o perfil dos mesmos, as responsabilidades de cada um, o nível e frequência de engajamento, a avaliação e as estratégias de monitoramento e controle.

O gerenciamento do engajamento das partes interessadas primárias envolveu diretamente o gerente de projetos, através de reuniões periódicas, uso de canais de comunicação virtual, visibilidade das ações a serem atendidas no projeto e cumprimento do cronograma do curso. $O$ gerenciamento do engajamento das partes secundárias foi realizado por toda equipe do projeto, através do acompanhamento direto na participação no curso e integração com os demais cursistas, ou seja, houve uma avaliação permanente de cada integrante.

Este processo de gerenciamento demandou mais do que gerenciar uma equipe. Envolveu o estabelecimento e a manutenção de relacionamentos entre as partes interessadas, com o objetivo de satisfazer suas respectivas necessidades e requisitos dentro dos limites do projeto. O principal benefício deste processo foi o 
aumento do nível de apoio às partes e minoração da resistência, ampliando de maneira significativa o êxito do projeto.

A última etapa deste processo, a de controle, serviu para efetivar 0 monitoramento dos relacionamentos, andamento do curso e ajustes de estratégias, quando necessário, agregando informações e registrando as lições aprendidas.

\section{EFETIVIDADE DAS AÇÕES CONTIDAS NO PLANO DE MONITORAMENTO E AVALIAÇÃO DO PROJETO EDUCACIONAL.}

A efetividade da gestão de projetos demanda a estruturação de um sistema de indicadores peculiares, palpáveis e periódicos que permitam monitorar sua implementação na lógica do ciclo de vida. São necessários indicadores que permitam monitorar os objetivos alcançados e os procedimentos realizados, focados na análise da eficiência e eficácia dos processos, sucedendo-se no tempo, com a finalidade de subsidiar o gerente de projetos com informações acerca dos recursos empregados e dos resultados e efeitos almejados.

William Edwards Deming (1900-1993), conhecido como o "profeta da qualidade" e "filósofo do gerenciamento", um dos nomes mais influentes no renascimento econômico do Japão, proferiu a célebre frase: "Não se gerencia o que não se mede, não se mede o que não se define, não se define o que não se entende, não há sucesso no que não se gerencia".

A palavra "sucesso" é utilizada para indicar alguma coisa desejável, planejada ou pretendida que foi realizada: ou seja, a entrega dos resultados do projeto no prazo, dentro do orçamento, ajustados à missão, aos objetivos e às metas do empreendimento. A determinação do sucesso ou do fracasso exige 0 desenvolvimento de padrões de desempenho no projeto, os quais podem ser comparados aos resultados produzidos (CLELAND; IRELAND, 2007).

Para o Guia PMBOK, o sucesso de um projeto deve ser medido em termos da sua conclusão dentro das restrições do âmbito, tempo, custo, qualidade, recursos e riscos, conforme aprovado entre os gestores de projeto e as equipes de gestão (PMI, 2013). Para Schmidt (2009), o sucesso relaciona-se com o processo de acompanhamento de todo o ciclo do projeto, desde a concepção até 
o encerramento, dando assim ênfase ao processo de monitorização e controle do projeto.

A construção de Planos de Monitoramento e Avaliação (PMA) constitui-se num dos elementos fundamentais para o gerenciamento de programas e projetos. Um PMA bem elaborado, atualizado e bem utilizado pode propiciar um significativo ganho de qualidade e eficiência gerenciais. É um instrumento que auxilia o gestor a selecionar, organizar e administrar as informações relevantes para a tomada de decisões estratégicas ou operacionais com foco principal na avaliação e análise de resultados decorrentes das diversas atividades desenvolvidas ao longo do projeto (MOURA; BARBOSA, 2011).

O PMA utilizado sob a ótica da avaliação do conhecimento e de aprendizagem é uma ferramenta poderosa para os projetos melhorarem seus processos de tomada de decisão e ajustarem as linhas de intervenção, de forma a obter maior conservação dos recursos, aliada ao maior benefício possível para suas populações-alvo e o sucesso do projeto (ASCHER; GUIMARÃES, 2004; BROCKE; ROSEMANN, 2013).

Quanto ao formato do PMA, não existe um padrão preestabelecido. Independente do formato, o mais importante é que este plano forneça aos gestores do projeto informações que facilitem o acompanhamento das atividades, a entrega dos serviços e a avaliação dos resultados. Projetos educacionais podem ser monitorados e avaliados com dados obtidos a partir de instrumentos simples e baseados em observações, análises documentais ou consultas diretas em grupos de discussão (MOURA; BARBOSA, 2011).

O Método do Quadro Lógico (Logical Framework ou simplesmente LogFrame) é uma metodologia que tem sido utilizada para o monitoramento e avaliação de projetos. Uma de suas características é a organização gráfica que sintetiza a dinâmica e os dados correspondentes aos objetos de monitoramento e avaliação sistemática dos projetos, além de sua flexibilidade e adaptabilidade a todas as condições novas, colaborando na transposição e/ou aproveitamento dos cenários que surgirem durante a execução do projeto (ÖRTENGREN, 2004).

O grande diferencial do Método do Quadro Lógico (MQL) é que ele utiliza como fundamento principal a participação de todos os gestores, monitorando as ações e expectativas de todos os participantes por meio de reuniões estruturadas, 
gerando como seu principal produto o Quadro Lógico (QL). Quando relacionado com o Guia PMBOK, por exemplo, pode-se verificar que o QL responde a maioria dos aspectos de gerenciamento de projeto organizados nas áreas de conhecimento do PMI (PFEIFFER, 2000).

Em outras palavras: com a aplicação do enfoque QL, pretende-se definir e mostrar o êxito de um projeto, através de um conjunto de conceitos interdependentes que descrevem de um modo operacional e organizado numa matriz os aspectos mais importantes de um projeto. Essa descrição permite, em primeiro lugar, verificar se um projeto está bem-estruturado e, em segundo lugar, o acompanhamento sistemático e uma avaliação mais fácil e mais objetiva (BACCARINI, 1999).

O PMA elaborado pelas pesquisadoras, utilizando o MQL possibilitou a identificação dos processos e atividades, quando realizados assim como a comparação dos resultados qualitativos e quantitativos alcançados, baseados nas metas estabelecidas e nos impactos do projeto relacionados ao seu objetivo geral. Os QL constituíram informações sobre PMA com ênfase em diagnóstico e documentação e dos referenciais metodológicos-conceituais por componentes do sistema educacional com ênfase em resultados esperados e indicadores de resultados.

Nas células da matriz do QL 10 estão descritos os itens do PMA e os meios de verificação de cada diagnóstico situacional previsto no plano, com ênfase nos objetivos traçados ao longo do planejamento e nas áreas de conhecimento do Guia PMBOK. Nas células da matriz do QL 11 foram mostrados os resultados esperados após a utilização dos referenciais teóricos que permitiram fazer contrapontos entre teorias no sentido de melhor fundamentar a qualidade do projeto assim como seus indicadores de resultados (benefícios diretos e estendidos), vistos na realidade como impactos do projeto.

Quadro 10. Matriz do Quadro lógico com Checklist do Plano de Monitoramento e Avaliação com ênfase em diagnóstico e documentação.

\begin{tabular}{|c|c|c|c|c|}
\hline $\mathbf{N}$ & ITEM & SIM & NÃO & MEIO DE VERIFICAÇÃO \\
\hline $\mathbf{1}$ & $\begin{array}{c}\text { Vínculo entre o Projeto e as } \\
\text { estratégias definidas }\end{array}$ & $X$ & & $\begin{array}{c}\text { Consultas diretas em grupos de } \\
\text { discussão, análise do PGP }\end{array}$ \\
\hline $\mathbf{2}$ & Definição do escopo do projeto & $\mathrm{X}$ & & Análise do Plano de \\
\hline
\end{tabular}




\begin{tabular}{|c|c|c|c|}
\hline & & & $\begin{array}{l}\text { gerenciamento do escopo do } \\
\text { projeto }\end{array}$ \\
\hline 3 & $\begin{array}{l}\text { Elaboração do Termo de } \\
\text { abertura do projeto }\end{array}$ & $X$ & Observação do Project Charper \\
\hline 4 & $\begin{array}{c}\text { Desenvolvimento do Plano de } \\
\text { Gerenciamento do Projeto } \\
\text { (PGP) }\end{array}$ & $X$ & $\begin{array}{c}\text { Checklist do PGP, do EAP e da } \\
\text { Matriz de design instrucional } \\
\text { geral }\end{array}$ \\
\hline 5 & $\begin{array}{l}\text { Elaboração do Plano de } \\
\text { Monitoramento e Avaliação } \\
\text { (PMA) }\end{array}$ & $X$ & $\begin{array}{l}\text { Monitoramento e avaliação } \\
\text { sistemática da execução e } \\
\text { resultados do projeto, com } \\
\text { planilhas de acompanhamento e } \\
\text { instrumento de coleta de dados }\end{array}$ \\
\hline 6 & $\begin{array}{c}\text { Estrutura analítica do projeto } \\
\text { concluída }\end{array}$ & $X$ & $\begin{array}{c}\text { Checklist das ações por unidade } \\
\text { de aprendizagem }\end{array}$ \\
\hline 7 & $\begin{array}{c}\text { Definição da estrutura de design } \\
\text { instrucional dos materiais e } \\
\text { ambiente virtual. }\end{array}$ & $X$ & $\begin{array}{c}\text { Consultas diretas em grupos de } \\
\text { discussão }\end{array}$ \\
\hline 8 & $\begin{array}{l}\text { Elaboração das atividades } \\
\text { estratégicas do curso e seu } \\
\text { sequenciamento }\end{array}$ & $X$ & $\begin{array}{l}\text { Consultas diretas em grupos de } \\
\text { discussão }\end{array}$ \\
\hline 9 & $\begin{array}{l}\text { Definição e contratação dos } \\
\text { recursos necessários }\end{array}$ & $\mathrm{X}$ & $\begin{array}{c}\text { Realização de reuniões e análise } \\
\text { documental dos contratos }\end{array}$ \\
\hline 10 & $\begin{array}{l}\text { Desenvolvimento dos materiais } \\
\text { e recursos didáticos }\end{array}$ & $X$ & Avaliação entre pares \\
\hline 11 & $\begin{array}{c}\text { Necessidades de produtos e } \\
\text { serviços definidos }\end{array}$ & $X$ & $\begin{array}{l}\text { Análise documental da lista de } \\
\text { produtos e serviços }\end{array}$ \\
\hline 12 & Pré-produção do curso & $\mathrm{X}$ & Análise documental do AVA \\
\hline 13 & Principais marcos definidos & $X$ & $\begin{array}{c}\text { Checklist do PGP, do EAP e da } \\
\text { Matriz de design instrucional } \\
\text { geral }\end{array}$ \\
\hline 14 & $\begin{array}{l}\text { Divulgação do curso em meios } \\
\text { de comunicação }\end{array}$ & $X$ & $\begin{array}{l}\text { Impressão e divulgação virtual de } \\
\text { materiais }\end{array}$ \\
\hline 15 & $\begin{array}{l}\text { Realização das matrículas das } \\
\text { partes interessadas }\end{array}$ & $X$ & $\begin{array}{l}\text { Análise documental do relatório } \\
\text { de matrículas }\end{array}$ \\
\hline 16 & $\begin{array}{l}\text { Liberação do curso na } \\
\text { plataforma }\end{array}$ & $X$ & $\begin{array}{l}\text { Consultas diretas em grupos de } \\
\text { discussão }\end{array}$ \\
\hline 17 & $\begin{array}{c}\text { Cumprimento do Cronograma } \\
\text { de Planejamento }\end{array}$ & $X$ & $\begin{array}{c}\text { Checklist do PGP, do EAP e da } \\
\text { Matriz de design instrucional } \\
\text { geral }\end{array}$ \\
\hline 18 & Gerenciamento da Qualidade & $X$ & $\begin{array}{l}\text { Consultas diretas em grupos de } \\
\text { discussão, análise do PGP, } \\
\text { cronograma, recursos, custos e } \\
\text { estratégias. }\end{array}$ \\
\hline 19 & $\begin{array}{c}\text { Gerenciamento dos Recursos } \\
\text { Humanos }\end{array}$ & $X$ & Análise do PGP e cronograma. \\
\hline 20 & $\begin{array}{l}\text { Gerenciamento das } \\
\text { Comunicações }\end{array}$ & $X$ & $\begin{array}{c}\text { Gestão das informações, meios e } \\
\text { tecnologias de comunicação, } \\
\text { relatórios formais }\end{array}$ \\
\hline 21 & Gerenciamento dos Riscos & $X$ & $\begin{array}{l}\text { Consultas diretas em grupos de } \\
\text { discussão e análise documental } \\
\text { das listas de verificação }\end{array}$ \\
\hline 22 & Gerenciamento das Aquisições & $\mathrm{X}$ & Identificação de demandas de \\
\hline
\end{tabular}




\begin{tabular}{|c|c|c|c|}
\hline & & & $\begin{array}{c}\text { produtos e recursos humanos } \\
\text { durante o plano de } \\
\text { gerenciamento e análise } \\
\text { documental dos contratos de } \\
\text { serviços }\end{array}$ \\
\hline 23 & $\begin{array}{l}\text { Gerenciamento das partes } \\
\text { interessadas no projeto }\end{array}$ & $x$ & $\begin{array}{l}\text { Consultas diretas em grupos de } \\
\text { discussão, análise das reuniões e } \\
\text { uso de canais de comunicação, } \\
\text { análise de cronograma }\end{array}$ \\
\hline 24 & $\begin{array}{l}\text { Controle integrado das } \\
\text { mudanças e recomendação de } \\
\text { ações corretivas }\end{array}$ & $\mathrm{X}$ & $\begin{array}{l}\text { Consultas diretas em grupos de } \\
\text { discussão e análise documental } \\
\text { das listas de verificação }\end{array}$ \\
\hline 25 & $\begin{array}{l}\text { Monitoramento das atividades } \\
\text { contínuas do projeto em relação } \\
\text { ao plano de gerenciamento do } \\
\text { projeto }\end{array}$ & $x$ & $\begin{array}{c}\text { Checklist do PGP, do EAP e da } \\
\text { Matriz de design instrucional } \\
\text { geral }\end{array}$ \\
\hline 26 & $\begin{array}{c}\text { Monitoramento por cursista de } \\
\text { acordo com as atividades de } \\
\text { aprendizagem }\end{array}$ & $x$ & $\begin{array}{c}\text { Checklist dos objetivos da Matriz } \\
\text { de design instrucional geral e } \\
\text { Análise das tarefas das unidades } \\
\text { de aprendizagem }\end{array}$ \\
\hline 27 & $\begin{array}{l}\text { Finalização de todos os } \\
\text { objetivos traçados no curso }\end{array}$ & $x$ & $\begin{array}{c}\text { Checklist do PGP, do EAP e da } \\
\text { Matriz de design instrucional } \\
\text { geral }\end{array}$ \\
\hline 28 & Encerramento dos contratos & $X$ & $\begin{array}{l}\text { Análise documental dos contratos } \\
\text { de serviços }\end{array}$ \\
\hline 29 & $\begin{array}{l}\text { Avaliação dos rendimentos } \\
\text { individuais de cada cursista } \\
\text { participante }\end{array}$ & $x$ & $\begin{array}{l}\text { Análise das tarefas e participação } \\
\text { nas unidades de aprendizagem }\end{array}$ \\
\hline 30 & $\begin{array}{l}\text { Análises sobre cada unidade de } \\
\text { aprendizagem através da visão } \\
\text { da equipe do projeto }\end{array}$ & $\mathrm{X}$ & $\begin{array}{l}\text { Consultas diretas em grupos de } \\
\text { discussão }\end{array}$ \\
\hline 31 & $\begin{array}{l}\text { Arquivamento dos registros do } \\
\text { projeto e relatos dos cursistas }\end{array}$ & $x$ & $\begin{array}{l}\text { Análise documental dos relatórios } \\
\text { administrativos }\end{array}$ \\
\hline 32 & $\begin{array}{l}\text { Gerenciamento dos custos e } \\
\text { orçamentos }\end{array}$ & $x$ & $\begin{array}{c}\text { Análise documental de tabelas e } \\
\text { planilhas financeiras }\end{array}$ \\
\hline 33 & $\begin{array}{l}\text { Estimativas de todas as tarefas } \\
\text { criadas pelos grupos }\end{array}$ & $x$ & $\begin{array}{c}\text { Análise documental das tarefas e } \\
\text { participação nas unidades de } \\
\text { aprendizagem }\end{array}$ \\
\hline 34 & $\begin{array}{c}\text { Elaboração dos relatórios } \\
\text { institucionais }\end{array}$ & $x$ & $\begin{array}{l}\text { Análise documental dos relatórios } \\
\text { administrativos }\end{array}$ \\
\hline 34 & $\begin{array}{l}\text { Requerimentos legais } \\
\text { concluídos }\end{array}$ & $\mathrm{X}$ & $\begin{array}{l}\text { Análise documental dos relatórios } \\
\text { administrativos }\end{array}$ \\
\hline 36 & $\begin{array}{c}\text { Definição se o mesmo projeto } \\
\text { educacional será novamente } \\
\text { aplicado, pela mesma equipe, } \\
\text { na mesma instituição de ensino, } \\
\text { na mesma modalidade }\end{array}$ & $x$ & $\begin{array}{l}\text { Consultas diretas em grupos de } \\
\text { discussão e confirmação de novo } \\
\text { projeto educacional }\end{array}$ \\
\hline 37 & $\begin{array}{l}\text { Resultado positivo do projeto } \\
\text { relativo ao objetivo geral }\end{array}$ & $x$ & Análise do PGP e PMA \\
\hline 38 & $\begin{array}{l}\text { Resultado positivo do projeto } \\
\text { relativo aos objetivos específico }\end{array}$ & $x$ & Análise do PGP e PMA \\
\hline
\end{tabular}

Fonte: A autora (2016) 
Os conjuntos de elementos contidos nos dois quadros, mesmo concisos, mostram os indicadores fundamentais que assinalam o grau de efetividade do projeto em foco. Tais elementos foram relacionados com os resultados esperados, a fim de servir de base de comparação para o processo de avaliação do projeto. Normalmente, para projetos educacionais, componentes como organização metodológica, ações docentes, material didático e ações discentes, são usados com frequência como fontes de informação.

Quadro 11. Matriz do Quadro lógico dos referenciais metodológicos-conceituais por componentes do sistema educacional com ênfase em resultados esperados e indicadores de resultados.

\begin{tabular}{|c|c|c|}
\hline $\begin{array}{l}\text { REFERENCIAIS/ } \\
\text { COMPONENTES }\end{array}$ & RESULTADOS & $\begin{array}{l}\text { INDICADORES DE } \\
\text { RESULTADOS }\end{array}$ \\
\hline $\begin{array}{l}\text { ORGANIZAÇÃO } \\
\text { METODOLÓGICA }\end{array}$ & $\begin{array}{c}\text { Flexibilização da } \\
\text { organização metodológica, } \\
\text { unidades de aprendizagem e } \\
\text { conteúdos, de acordo com a } \\
\text { carga horária e objetivos } \\
\text { específicos }\end{array}$ & $\begin{array}{l}\text { Estruturas metodológicas } \\
\text { e de aprendizagem em } \\
\text { funcionamento }\end{array}$ \\
\hline $\begin{array}{l}\text { ORGANIZAÇÃO } \\
\text { METODOLÓGICA }\end{array}$ & $\begin{array}{c}\text { Organização metodológica } \\
\text { com ênfase no processo de } \\
\text { ensino e não apenas no } \\
\text { conteúdo }\end{array}$ & $\begin{array}{l}\text { Unidades de } \\
\text { aprendizagem aplicando }\end{array}$ \\
\hline $\begin{array}{l}\text { ORGANIZAÇÃO } \\
\text { METODOLÓGICA }\end{array}$ & $\begin{array}{c}\text { Incorporação de temas } \\
\text { voltados a recursos didáticos } \\
\text { tecnológicos }\end{array}$ & $\begin{array}{c}\text { Unidades de } \\
\text { aprendizagem especificas } \\
\text { para atuação docente na } \\
\text { era digital }\end{array}$ \\
\hline $\begin{array}{l}\text { ORGANIZAÇÃO } \\
\text { METODOLÓGICA }\end{array}$ & $\begin{array}{l}\text { Implementação de práticas } \\
\text { inovadoras de aprendizagem }\end{array}$ & $\begin{array}{l}\text { Cursistas apresentando } \\
\text { iniciativas geradas pela } \\
\text { motivação das práticas }\end{array}$ \\
\hline $\begin{array}{l}\text { ORGANIZAÇÃO } \\
\text { METODOLÓGICA }\end{array}$ & $\begin{array}{l}\text { Interfaces de aprendizagem } \\
\text { estruturadas para facilitar os } \\
\text { contatos e a construção do } \\
\text { conhecimento entre os } \\
\text { participantes no AVA }\end{array}$ & $\begin{array}{c}\text { Trocas sociais de } \\
\text { conhecimento entre } \\
\text { professores, tutores e } \\
\text { cursistas (intrapessoais), } \\
\text { com ênfase na discussão } \\
\text { em grupo e no poder de } \\
\text { argumentação }\end{array}$ \\
\hline DOCENTE/TUTOR & $\begin{array}{l}\text { Atitude de revisão crítica e } \\
\text { continuada da prática } \\
\text { pedagógica adotando } \\
\text { métodos de construção } \\
\text { participativa do } \\
\text { conhecimento }\end{array}$ & $\begin{array}{l}\text { Professores e Tutores } \\
\text { evidenciando mudanças } \\
\text { na construção } \\
\text { participativa do } \\
\text { conhecimento e uma } \\
\text { posição crítica diante da } \\
\text { prática pedagógica }\end{array}$ \\
\hline DOCENTE/TUTOR & Capacidade de autonomia & Professores produzindo \\
\hline
\end{tabular}




\begin{tabular}{|c|c|c|}
\hline & $\begin{array}{l}\text { para educação a distância e } \\
\text { ambientes virtuais na } \\
\text { elaboração de materiais e as } \\
\text { fontes de comunicação }\end{array}$ & $\begin{array}{l}\text { materiais de bom nível; } \\
\text { Tutores demonstrando } \\
\text { facilidade de } \\
\text { comunicação com os } \\
\text { cursistas. }\end{array}$ \\
\hline DOCENTE/TUTOR & $\begin{array}{l}\text { Adoção de uma nova } \\
\text { posição teórico-prática em } \\
\text { relação as estratégias de } \\
\text { ensino e avaliação }\end{array}$ & $\begin{array}{c}\text { Professores e Tutores } \\
\text { adotando metodologias } \\
\text { de ensino-aprendizagem } \\
\text { com foco nos referenciais } \\
\text { teóricos do projeto }\end{array}$ \\
\hline DOCENTE/TUTOR & $\begin{array}{l}\text { Gestão do conhecimento } \\
\text { prévio dos cursistas } \\
\text { paralelamente ao novo que } \\
\text { esta sendo apresentado de } \\
\text { forma a alcançar os objetivos } \\
\text { programados }\end{array}$ & $\begin{array}{c}\text { Avanços espontâneos do } \\
\text { conhecimento }\end{array}$ \\
\hline DOCENTE/TUTOR & $\begin{array}{c}\text { Mediação da aprendizagem } \\
\text { por meio de instrumentos e } \\
\text { signos }\end{array}$ & $\begin{array}{c}\text { Utilização das } \\
\text { ferramentas de chat, na } \\
\text { linguagem adotada para } \\
\text { a comunicação, nos } \\
\text { serviços de e-mail, de } \\
\text { fórum, na vídeo e } \\
\text { teleconferência, em toda } \\
\text { ferramenta que exerça a } \\
\text { função de mediação }\end{array}$ \\
\hline DOCENTE/TUTOR & $\begin{array}{c}\text { Ensino reflexivo para } \\
\text { reconstrução ou } \\
\text { reorganização da } \\
\text { experiência adicionada ao } \\
\text { significado da experiência do } \\
\text { cursista }\end{array}$ & $\begin{array}{l}\text { Capacidade dos cursistas } \\
\text { em conduzir o destino da } \\
\text { experiência subsequente }\end{array}$ \\
\hline $\begin{array}{l}\text { MATERIAL } \\
\text { DIDÁTICO }\end{array}$ & $\begin{array}{l}\text { Material didático produzidos } \\
\text { pelos professores e } \\
\text { utilizados como incentivo ao } \\
\text { estudo e a pesquisa }\end{array}$ & $\begin{array}{c}\text { Existência de materiais } \\
\text { diversificados acessados } \\
\text { e elogiados } \\
\text { continuamente pelos } \\
\text { cursistas }\end{array}$ \\
\hline $\begin{array}{l}\text { MATERIAL } \\
\text { DIDÁTICO }\end{array}$ & $\begin{array}{l}\text { Recursos diversificados e } \\
\text { interativos, fundamentados } \\
\text { na educação da cibercultura }\end{array}$ & $\begin{array}{c}\text { Melhoria gradativa do } \\
\text { desempenho dos } \\
\text { cursistas nas atividades } \\
\text { propostas coletivamente } \\
\text { com uso de ferramentas } \\
\text { tecnológicas }\end{array}$ \\
\hline $\begin{array}{l}\text { MATERIAL } \\
\text { DIDÁTICO }\end{array}$ & $\begin{array}{l}\text { Relação dos materiais com } \\
\text { um novo conhecimento e } \\
\text { uma nova dinâmica na } \\
\text { relação entre homem, } \\
\text { tecnologia e ambiente de } \\
\text { aprendizagem }\end{array}$ & $\begin{array}{c}\text { Estabelecimento e } \\
\text { compreensão de outras } \\
\text { formas de aprendizagem } \\
\text { e construção do } \\
\text { conhecimento }\end{array}$ \\
\hline
\end{tabular}




\begin{tabular}{|c|c|c|}
\hline CURSISTA & $\begin{array}{l}\text { Ampliação da autonomia de } \\
\text { aprendizagem }\end{array}$ & $\begin{array}{l}\text { Cursistas superando os } \\
\text { desafios propostos nas } \\
\text { unidades de } \\
\text { aprendizagem com } \\
\text { facilidade progressiva e } \\
\text { protagonistas do seu } \\
\text { processo de } \\
\text { aprendizagem }\end{array}$ \\
\hline CURSISTA & $\begin{array}{l}\text { Modificação de } \\
\text { comportamento na } \\
\text { aprendizagem }\end{array}$ & $\begin{array}{l}\text { Mudança da atitude de } \\
\text { recepção passiva do } \\
\text { conhecimento para } \\
\text { construção coletiva }\end{array}$ \\
\hline CURSISTA & $\begin{array}{c}\text { Adoção de uma nova } \\
\text { posição profissional reflexiva }\end{array}$ & $\begin{array}{c}\text { Ampliação da consciência } \\
\text { dos recursos } \\
\text { pedagógicos na } \\
\text { educação e reflexão } \\
\text { sobre a sua prática, com } \\
\text { desenvolvimento do } \\
\text { pensamento e da ação }\end{array}$ \\
\hline CURSISTA & $\begin{array}{l}\text { Capacitação para uso dos } \\
\text { materiais didáticos }\end{array}$ & $\begin{array}{c}\text { Autonomia para } \\
\text { elaboração de próprios } \\
\text { materiais didáticos }\end{array}$ \\
\hline CURSISTA & $\begin{array}{l}\text { Compreensão da prática } \\
\text { educativa para cidadania }\end{array}$ & $\begin{array}{l}\text { Participação ativa no } \\
\text { processo de ensino e } \\
\text { aprendizagem }\end{array}$ \\
\hline CURSISTA & $\begin{array}{c}\text { Desenvolvimento da } \\
\text { aprendizagem através de } \\
\text { novas concepções e } \\
\text { linguagens, interagindo com } \\
\text { a sociedade da informação, } \\
\text { habilitando-se a lidar com as } \\
\text { tecnologias digitais de forma } \\
\text { participativa }\end{array}$ & $\begin{array}{l}\text { Compreensão das } \\
\text { peculiaridades da } \\
\text { dinâmica interativa que } \\
\text { as ferramentas } \\
\text { tecnológicas } \\
\text { proporcionam aos } \\
\text { sujeitos da ação } \\
\text { educativa }\end{array}$ \\
\hline
\end{tabular}

Fonte: A autora (2016)

Também foram utilizadas para embasamento no PMA um Checklist do Plano de Controle do Cronograma do curso (Quadro 12) e a análise de uma tabela das tarefas e participação nas unidades de aprendizagem por cursista (Quadro 13). Neste ponto do desenvolvimento dos procedimentos de avaliação do projeto, foi importante analisar os quadros gerais elaborados, procurando verificar as possibilidades de agregação de resultados semelhantes, referindo-se aos mesmos objetivos, mesmo que redigidos de formas diferentes. 
Quadro 12. Checklist do Plano de Controle do Cronograma do curso.

\begin{tabular}{|c|c|c|c|c|c|c|c|}
\hline \multicolumn{3}{|c|}{$\begin{array}{c}\text { Nome do Projeto } \\
\text { Curso de Atualização: } \\
\text { Tecnologias Digitais de } \\
\text { Informação e Comunicação na } \\
\text { Educação }\end{array}$} & \multicolumn{3}{|c|}{$\begin{array}{c}\text { Gerentes } \\
\text { Profa. Cláudia Prado } \\
\text { Profa. Maria Madalena } \\
\text { Januário Leite }\end{array}$} & \multicolumn{2}{|c|}{$\begin{array}{c}\text { Instituição } \\
\text { Escola de Enfermagem da } \\
\text { Universidade de São Paulo }\end{array}$} \\
\hline \multicolumn{6}{|c|}{ CRONOGRAMA } & \multicolumn{2}{|c|}{ CONTROLE } \\
\hline \multicolumn{3}{|c|}{ Fase de Iniciação } & \multicolumn{3}{|c|}{05.02 .15 a 05.04 .15} & \multicolumn{2}{|c|}{ OK } \\
\hline \multicolumn{3}{|c|}{ Fase de Planejamento } & \multicolumn{3}{|c|}{05.03 .15 a 15.10 .15} & \multicolumn{2}{|c|}{ OK } \\
\hline \multicolumn{3}{|c|}{ Fase de Execução } & \multicolumn{3}{|c|}{15.09 .15 a 15.12 .15} & \multicolumn{2}{|c|}{ OK } \\
\hline \multicolumn{3}{|c|}{$\begin{array}{l}\text { Fase de Monitoramento e } \\
\text { Controle }\end{array}$} & \multicolumn{3}{|c|}{15.04 .15 a 15.01 .16} & \multicolumn{2}{|c|}{ OK } \\
\hline \multicolumn{3}{|c|}{ Fase de Encerramento } & \multicolumn{3}{|c|}{15.12 .15 a 15.02 .16} & \multicolumn{2}{|c|}{ OK } \\
\hline \multicolumn{8}{|c|}{ LISTA DE ATIVIDADES } \\
\hline Unid & $\begin{array}{c}\text { Cronograma } \\
\text { de } \\
\text { Planejamento }\end{array}$ & & $\begin{array}{r}\text { Crono } \\
\text { de Exe } \\
\text { Monitore } \\
\text { Con }\end{array}$ & & & $\begin{array}{l}\text { Cronograma de } \\
\text { Encerramento }\end{array}$ & \\
\hline 1 & \multirow{9}{*}{30.07 .2015} & OK & \multicolumn{2}{|c|}{15.09 .15 a 21.09 .15} & OK & 15.12 .15 & OK \\
\hline 2 & & OK & 22.09 .15 & 9.15 & OK & 15.12 .15 & OK \\
\hline 3 & & OK & 29.09 .15 & 0.15 & OK & 15.12 .15 & OK \\
\hline 4 & & OK & 13.10 .15 & 0.15 & OK & 15.12 .15 & OK \\
\hline 5 & & OK & 20.10 .15 & 0.15 & OK & 15.12 .15 & OK \\
\hline 6 & & OK & 27.10 .15 & 1.15 & OK & 15.12 .15 & OK \\
\hline 7 & & OK & 10.11 .15 & 1.15 & OK & 15.12 .15 & OK \\
\hline 8 & & OK & 17.11 .15 & 1.15 & OK & 15.12 .15 & OK \\
\hline 9 & & OK & 24.11 .15 & 2.15 & $\mathrm{OK}$ & 30.12 .15 & OK \\
\hline & CRONOGRAM & DE RE & NIÕES DA & IIPE & & $\begin{array}{l}\text { CONTRO } \\
\text { REALIZA }\end{array}$ & \\
\hline Gestor & e Professores & & & 05.0 & & OK & \\
\hline Gestor & , Professores e & esign I & rucional & 05.0 & & OK & \\
\hline Gestor & e Equipe TI & & & 10.0 & & OK & \\
\hline Gestor & e Equipe Admir & trativa & & 01.0 & & OK & \\
\hline Gestor & e Professores & & & 05.0 & & OK & \\
\hline Gestor & e Professores & & & 05.0 & & OK & \\
\hline Gestor & e Professores & & & 05.0 & & OK & \\
\hline Gestor & e Equipe Admir & trativa & & 14.0 & & OK & \\
\hline Gestor & e Professores & & & 05.0 & & OK & \\
\hline Gestor & , Professores e & itores & & 05.0 & & OK & \\
\hline Gestor & , Professores e & tores & & 15.0 & & OK & \\
\hline Gestor & Professores e & tores & & 22.0 & & OK & \\
\hline Gestor & , Professores e & tores & & 28.0 & & OK & \\
\hline Gestor & e Professores & & & 13.1 & & OK & \\
\hline Gestor & Professores e & tores & & 29.0 & & OK & \\
\hline Gestor & , Professores e & itores & & 13.1 & & OK & \\
\hline Gestor & , Professores e & tores & & 20.1 & & OK & \\
\hline Gestor & , Professores e & tores & & 27.1 & & OK & \\
\hline Gestor & , Professores e & tores & & 10.1 & & OK & \\
\hline Gestor & , Professores e & tores & & 17.1 & & OK & \\
\hline Gestor & , Professores e & tores & & 25.1 & & OK & \\
\hline Gestor & , Professores e & itores & & 21.1 & & OK & \\
\hline Gestor & e Professores & & & 15.0 & & OK & \\
\hline Gestor & e Equipe Admir & trativa & & 15.0 & & OK & \\
\hline & RECUR & $\overline{\mathrm{OS} \mathrm{DA}}$ & ATIVIDAD & & & CONTROLE D & GTOS \\
\hline Remun & ração dos Tutore & & & $\mathrm{R} \$ 1$ & 00,00 & OK & \\
\hline
\end{tabular}




\begin{tabular}{|l|c|c|}
\hline Encargos Administrativos & $\mathrm{R} \$ 360,00$ & OK \\
\hline Remuneração do Design Gráfico & $\mathrm{R} \$ 5000,00$ & OK \\
\hline Material gráfico & $\mathrm{R} \$ 540,00$ & OK \\
\hline Recolhimento CEAP-EEUSP & $\mathrm{R} \$ 800,00$ & OK \\
\hline Receitas de Inscrições & $\mathrm{R} \$ 10000,00$ & OK \\
\hline
\end{tabular}

\begin{tabular}{|l|c|c|}
\hline \multicolumn{2}{|c|}{ RECURSOS HUMANOS } & NOME \\
\hline Gestores do Projeto & 02 & \\
\hline $\begin{array}{l}\text { Coordenadores de Unidades de } \\
\text { Aprendizagem/Conteúdistas }\end{array}$ & 03 & \\
\hline Tutores/Motivadores & 02 & \\
\hline Analistas de Suporte Técnico & 03 & \\
\hline Designer Instrucional & 01 & \\
\hline
\end{tabular}

Fonte: A autora (2016)

Desta forma, o conjunto de informações dos QL, do Plano de Controle de Cronograma e a tabela de participação dos cursistas nas unidades de aprendizagem, assim como sua avaliação final do curso, constituíram o PMA deste projeto. A técnica de análise documental dos processos foi bastante utilizada e referiu-se a consulta contínua de informações nas documentações disponíveis no ambiente virtual de aprendizagem, nos órgãos administrativos da instituição proponente e nos relatórios elaborados pela equipe gestora, todos softwares habituais de mercado, tais como planilhas eletrônicas e processadores de texto.

Quadro 13. Tabela das tarefas e participação nas unidades de aprendizagem por cursista.

\begin{tabular}{|c|c|c|c|c|c|c|c|c|c|c|}
\hline CURSISTAS & M1 & M2 & M3 & M & & M5 & M6 & M7 & M8 & AVALIAÇÃO FINAL \\
\hline 1 & $\mathbf{x}$ & $\mathbf{x}$ & $\mathbf{x}$ & $\mathrm{x}$ & & $x$ & $\mathbf{x}$ & $x$ & $x$ & $\mathbf{X}$ \\
\hline 2 & $\mathbf{X}$ & $\mathbf{X}$ & $\mathbf{X}$ & $\mathbf{x}$ & & $\mathbf{X}$ & $\mathbf{X}$ & $\mathbf{X}$ & $\mathbf{X}$ & $\mathbf{X}$ \\
\hline 3 & $\mathbf{X}$ & $\mathbf{X}$ & & $\bar{x}$ & & $\mathbf{X}$ & $\mathbf{X}$ & $\mathbf{X}$ & $\mathbf{X}$ & $\mathbf{X}$ \\
\hline 4 & $\mathbf{X}$ & $\mathbf{X}$ & $\mathbf{X}$ & 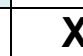 & & $\mathbf{X}$ & $\mathbf{X}$ & $\mathbf{X}$ & $\mathbf{X}$ & $\mathbf{X}$ \\
\hline 5 & $\mathbf{X}$ & $\mathbf{X}$ & $\mathbf{X}$ & $\mathbf{x}$ & & & $\mathbf{X}$ & $\mathbf{X}$ & $\mathbf{X}$ & $\mathbf{X}$ \\
\hline 6 & $\mathbf{X}$ & $\mathbf{X}$ & $\mathbf{X}$ & $\bar{x}$ & & & $\mathbf{X}$ & $\mathbf{X}$ & $\mathbf{X}$ & $\mathbf{X}$ \\
\hline 7 & \multicolumn{10}{|c|}{ DESISTENTE } \\
\hline 8 & \multicolumn{10}{|c|}{ DESISTENTE } \\
\hline 9 & & $\bar{X}$ & $\mathbf{X}$ & $\mathbf{X}$ & $\mathbf{X}$ & $\mathbf{X}$ & $\mathbf{X}$ & $\mathbf{X}$ & $\mathbf{X}$ & \\
\hline 10 & & & $\mathbf{X}$ & $\mathbf{X}$ & $\mathbf{x}$ & $\mathbf{X}$ & $\mathbf{X}$ & $\mathbf{X}$ & $\mathbf{X}$ & $\mathbf{X}$ \\
\hline 11 & & $\mathbf{X}$ & $\mathbf{X}$ & $\mathbf{X}$ & $\mathbf{X}$ & $\mathbf{X}$ & $\mathbf{X}$ & $\mathbf{X}$ & $\mathbf{X}$ & $\mathbf{X}$ \\
\hline 12 & & $\bar{x}$ & $\mathbf{X}$ & $\mathbf{X}$ & $\mathbf{X}$ & $\mathbf{X}$ & $\mathbf{X}$ & $\mathbf{X}$ & $\mathbf{X}$ & \\
\hline 13 & \multicolumn{10}{|c|}{ DESISTENTE } \\
\hline 14 & & $\mathbf{X}$ & $\mathbf{X}$ & $\mathbf{X}$ & $\mathbf{X}$ & $\mathbf{X}$ & $\mathbf{X}$ & $X$ & $X$ & $\mathbf{X}$ \\
\hline 15 & & $\mathbf{X}$ & $\mathbf{X}$ & $\mathbf{X}$ & $\mathbf{X}$ & $\mathbf{X}$ & $\mathbf{X}$ & $\mathbf{X}$ & $\mathbf{X}$ & $\mathbf{X}$ \\
\hline
\end{tabular}




\begin{tabular}{|c|c|c|c|c|c|c|c|c|c|}
\hline 16 & $\mathbf{x}$ & $\mathbf{x}$ & $\mathbf{x}$ & \multicolumn{6}{|c|}{ DESISTENTE } \\
\hline 17 & $\mathbf{X}$ & $\mathbf{X}$ & $\mathbf{X}$ & $\mathbf{X}$ & $\mathbf{X}$ & & $\mathbf{X}$ & $\mathbf{X}$ & $\mathbf{X}$ \\
\hline 18 & $\mathbf{X}$ & $\mathbf{X}$ & $\mathbf{X}$ & $\mathbf{X}$ & $\mathbf{X}$ & $\mathbf{X}$ & $\mathbf{X}$ & $\mathbf{X}$ & $\mathbf{X}$ \\
\hline 19 & $\mathbf{X}$ & $\mathbf{X}$ & $\mathbf{X}$ & $\mathbf{X}$ & $\mathbf{X}$ & $\mathbf{X}$ & $\mathbf{X}$ & $\mathbf{X}$ & $\mathbf{X}$ \\
\hline 20 & $\mathbf{X}$ & $\mathbf{X}$ & $\mathbf{X}$ & $\mathbf{X}$ & $\mathbf{X}$ & \multirow{2}{*}{\multicolumn{4}{|c|}{ DESISTENTE }} \\
\hline 21 & $\mathbf{X}$ & $\mathbf{X}$ & $\mathbf{X}$ & $\mathbf{X}$ & $\mathbf{X}$ & $\mathbf{X}$ & & & $\mathbf{X}$ \\
\hline 22 & $\mathbf{X}$ & $\mathbf{X}$ & $\mathbf{X}$ & $\mathbf{X}$ & $\mathbf{X}$ & $\mathbf{X}$ & $\mathbf{X}$ & $\mathbf{X}$ & $\mathbf{X}$ \\
\hline 23 & \multicolumn{9}{|c|}{ DESISTENTE } \\
\hline 24 & $\mathbf{X}$ & & & & & & ESIS & TEN & \\
\hline 25 & $\mathbf{X}$ & $\mathbf{X}$ & & $\mathbf{X}$ & $\mathbf{X}$ & $\mathbf{X}$ & $\mathbf{X}$ & $\mathbf{X}$ & $\mathbf{X}$ \\
\hline 26 & $\mathbf{X}$ & $\mathbf{X}$ & $\mathbf{X}$ & $\mathbf{X}$ & $\mathbf{X}$ & $\mathbf{X}$ & $\mathbf{X}$ & $\mathbf{X}$ & $\mathbf{X}$ \\
\hline 27 & $\mathbf{X}$ & & $\mathbf{X}$ & $\mathbf{X}$ & \multirow{2}{*}{\multicolumn{5}{|c|}{ DESISTENTE }} \\
\hline 28 & $\mathbf{X}$ & $\mathbf{X}$ & $\mathbf{X}$ & $\mathbf{X}$ & $\mathbf{X}$ & $\mathbf{X}$ & & & $\mathbf{X}$ \\
\hline 29 & \multicolumn{9}{|c|}{ DESISTENTE } \\
\hline 30 & $\mathbf{X}$ & $\mathbf{X}$ & $\mathbf{X}$ & $\mathbf{X}$ & $\mathbf{X}$ & $\mathbf{X}$ & $\mathbf{X}$ & $\mathbf{X}$ & $\mathbf{X}$ \\
\hline 31 & $\mathbf{X}$ & $\mathbf{X}$ & $\mathbf{X}$ & $\mathbf{X}$ & $\mathbf{X}$ & $\mathbf{X}$ & $\mathbf{X}$ & $\mathbf{X}$ & $\mathbf{X}$ \\
\hline 32 & $\mathbf{X}$ & $\mathbf{X}$ & $\mathbf{X}$ & $\mathbf{X}$ & $\mathbf{X}$ & $\mathbf{X}$ & $\mathbf{X}$ & $\mathbf{X}$ & $\mathbf{X}$ \\
\hline 33 & $\mathbf{X}$ & $\mathbf{X}$ & $\mathbf{X}$ & $\mathbf{X}$ & $\mathbf{X}$ & $\mathbf{X}$ & & $\mathbf{X}$ & \\
\hline 34 & $\mathbf{X}$ & $\mathbf{X}$ & $\mathbf{X}$ & $\mathbf{X}$ & $\mathbf{X}$ & $\mathbf{X}$ & $\mathbf{X}$ & $\mathbf{X}$ & $\mathbf{X}$ \\
\hline 35 & $\mathbf{X}$ & $\mathbf{X}$ & $\mathbf{X}$ & $X$ & $\mathbf{X}$ & $\mathbf{X}$ & $\mathbf{X}$ & $\mathbf{X}$ & $\mathbf{X}$ \\
\hline 36 & $\mathbf{X}$ & $\mathbf{X}$ & $\mathbf{X}$ & $\mathbf{X}$ & $\mathrm{X}$ & $\mathbf{X}$ & $\mathbf{X}$ & $\mathbf{X}$ & $\mathrm{x}$ \\
\hline 37 & $\mathbf{X}$ & $\mathbf{X}$ & $\mathbf{X}$ & $X$ & $\mathbf{X}$ & $\mathbf{X}$ & $\mathbf{X}$ & $\mathbf{X}$ & $\mathbf{X}$ \\
\hline 38 & $\mathbf{X}$ & $\mathbf{X}$ & $\mathbf{X}$ & $X$ & $\mathbf{X}$ & $\mathbf{X}$ & $\mathbf{X}$ & $\mathbf{X}$ & $\mathbf{X}$ \\
\hline 39 & $\mathbf{X}$ & $\mathbf{X}$ & $\mathbf{X}$ & $X$ & $\mathbf{X}$ & $\mathbf{X}$ & $\mathbf{X}$ & $\mathbf{X}$ & $\mathbf{X}$ \\
\hline 40 & $\mathbf{X}$ & $\mathbf{X}$ & $\mathbf{X}$ & $X$ & $\mathbf{X}$ & $\mathbf{X}$ & & $\mathbf{X}$ & $\mathbf{X}$ \\
\hline 41 & $\mathbf{X}$ & $\mathbf{X}$ & $\mathbf{X}$ & $X$ & $\mathbf{X}$ & $\mathbf{X}$ & $\mathbf{X}$ & $\mathbf{X}$ & $\mathbf{X}$ \\
\hline 42 & $\mathbf{X}$ & $\mathbf{X}$ & $\mathbf{X}$ & $X$ & $\mathbf{X}$ & $\mathbf{X}$ & $\mathbf{X}$ & $\mathbf{X}$ & $\mathbf{X}$ \\
\hline 43 & \multicolumn{9}{|c|}{ DESISTENTE } \\
\hline 44 & $\mathbf{X}$ & $\mathbf{X}$ & $\mathbf{X}$ & $X$ & $\mathbf{X}$ & $\mathbf{X}$ & $\mathbf{X}$ & $\mathbf{X}$ & $\mathbf{X}$ \\
\hline 45 & $\mathbf{X}$ & $\mathbf{X}$ & $\mathbf{X}$ & $X$ & $\mathbf{X}$ & $\mathbf{X}$ & $\mathbf{X}$ & $\mathbf{X}$ & $\mathbf{X}$ \\
\hline 46 & $\mathbf{X}$ & $\mathbf{X}$ & $\mathbf{X}$ & $X$ & $\mathbf{X}$ & $\mathbf{X}$ & $\mathbf{X}$ & $\mathbf{X}$ & \\
\hline 47 & $\mathbf{X}$ & $\mathbf{X}$ & $\mathbf{X}$ & $\mathbf{X}$ & $\mathbf{X}$ & $\mathbf{X}$ & $\mathbf{X}$ & $\mathbf{X}$ & $\mathbf{X}$ \\
\hline 48 & $\mathbf{X}$ & $\mathbf{X}$ & $\mathbf{X}$ & $X$ & $\mathbf{X}$ & $\mathbf{X}$ & $\mathbf{X}$ & $\mathbf{X}$ & $\mathbf{X}$ \\
\hline 49 & $\mathbf{X}$ & $\mathbf{X}$ & $\mathbf{X}$ & $X$ & $\mathbf{X}$ & $\mathbf{X}$ & $\mathbf{X}$ & $\mathbf{X}$ & $\mathbf{X}$ \\
\hline 50 & $\mathbf{X}$ & $\mathbf{X}$ & \multicolumn{7}{|c|}{ DESISTENTE } \\
\hline Postaram & 43 & 42 & 40 & 41 & 36 & 35 & 34 & 39 & 35 \\
\hline Não Postaram & 3 & 3 & 4 & 3 & 8 & 9 & 10 & 0 & 4 \\
\hline Desistentes & 4 & 5 & 6 & 6 & 6 & 6 & 6 & 11 & 11 \\
\hline
\end{tabular}

Fonte: A autora (2016)

Concluintes: 39

Existe muita controvérsia na literatura a respeito de como aferir o desempenho ou sucesso dos projetos. O sucesso pode ser visto sobre vários aspetos e na perspectiva de diferentes interessados. Portanto, pensar formas de 
monitorar e avaliar este projeto foi mais um grande desafio, em especial, quando a sociedade e a ciência demanda velocidade de respostas e sistemas de indicadores ao longo do desenvolvimento.

O PMA escolhido teve em mente alimentar o processo de ação e reação, com análises críticas de aspectos distintos e complementares. O PMA acompanhou as variações entre o previsto e o realizado desde as dimensões básicas de prazo, custo e escopo, tradicionais em projetos administrativos, até dimensões andragógicas e tecnológicas, específicas deste projeto educacional.

Para Carvalho e Rabechini Júnior (2015), quando se idealiza avaliação de projetos, é necessário discernir entre o sucesso da gestão do projeto, o sucesso do produto/serviço e os benefícios gerados para o negócio tanto com impacto na competição de mercado, quanto nos usuários dos produtos/serviços. Portanto, este PMA procurou equacionar estes parâmetros avaliativos, considerando a visão dos gestores, a utilização do Guia PMBOK e a participação/envolvimento dos cursistas.

O consenso dos gestores foi que este projeto pode ser considerado um sucesso, considerando as expectativas de efetividade e eficácia do planejamento e sua execução, assim como a satisfação dos cursistas. Os gestores e sua equipe também consideraram exitosas as dimensões dos sistemas de tecnologias digitais de informação e comunicação, os benefícios para a instituição proponente e o benefícios para a equipe idealizadora do projeto, no sentido de desenvolvimento pessoal, aprendizado profissional e satisfação com o resultado final.

A perspectiva temporal, considerando o impacto presente e futuro, foi a última contribuição deste projeto. $O$ anseio de organizar um curso de capacitação de profissionais no uso de TDIC como recursos pedagógicos em paralelo aos questionamentos de planejamento, modelo de gerenciamento e competências tornou-se ínfimo, diante da convicção de que uma nova linha de serviço (curso) baseada em uma competência gerencial desenvolvida através do Guia PMBOK foi elaborada para ser reproduzida no futuro. 


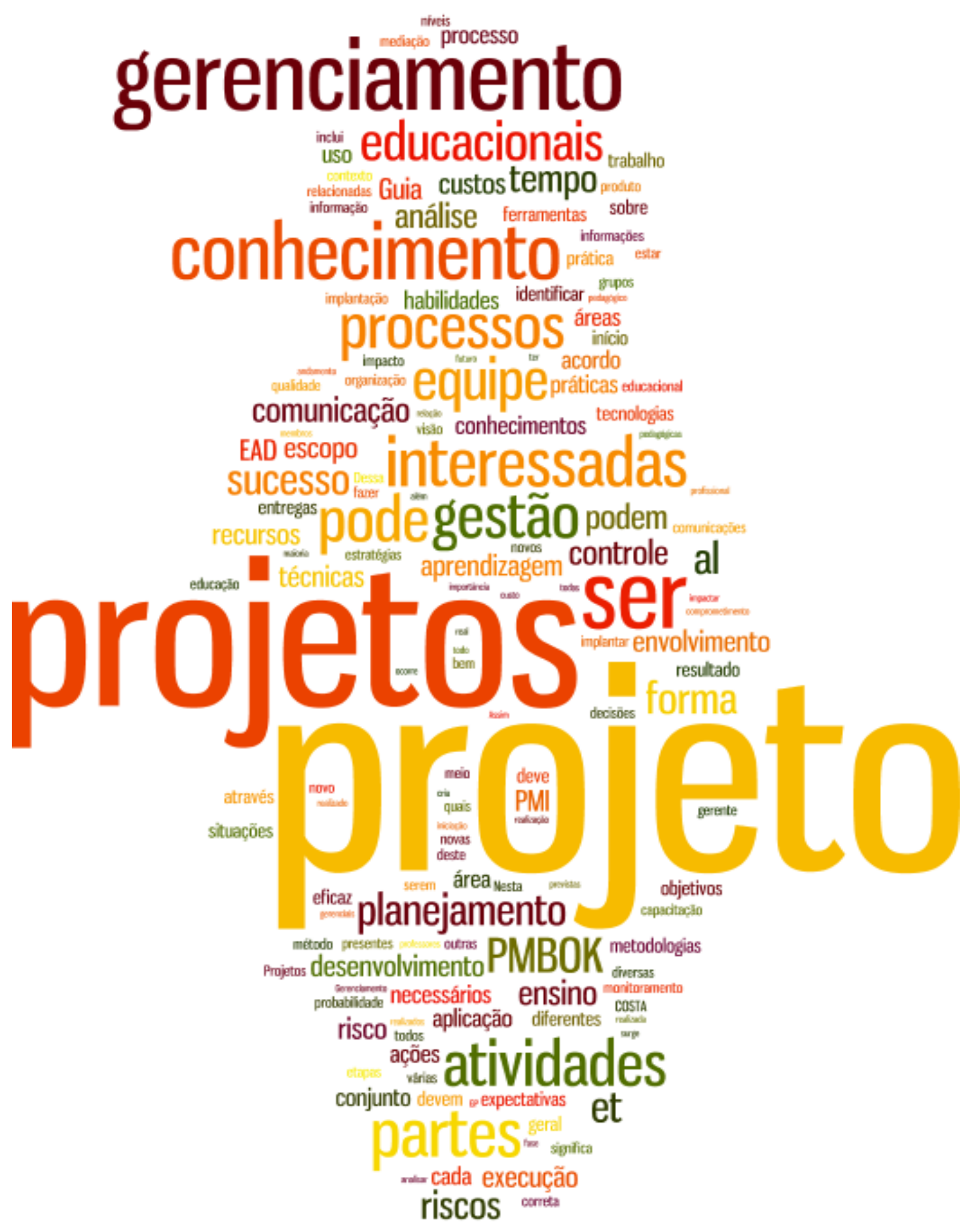

DISCUSSÃO 


\section{DISCUSSÃO}

As pesquisas que analisam as práticas de projetos aplicados a gestão do conhecimento, ou seja, projetos educacionais, tem comprovado que as vidas reais destes projetos podem ser complexas porém previsíveis e multidimensionais de acordo com o modelo adotado. Atualmente novas formas de pensar projetos introduziram a importância da interação entre as equipes, no estabelecimento de ciclos de vida na busca de um propósito comum.

O ciclo de vida do projeto serve para definir o início e o fim do projeto e define qual o trabalho deve ser realizado em cada fase e quem deve estar envolvido. Ele descreve o conjunto de processos que devem ser seguidos para que o projeto seja bem gerenciado (DINSMORE; CAVALIERI, 2009).

À medida que mais informações ou características do projeto são coletadas e entendidas, pode ser necessário um planejamento adicional. Mudanças significativas ocorridas ao longo do ciclo de vida do projeto acionam uma necessidade de revisitar o processo de planejamento e possivelmente alguns dos processos de iniciação, sendo denominado como "planejamento por ondas sucessivas", indicando que o planejamento e a documentação são atividades iterativas e contínuas (PMBOK, 2013).

Lopes (2010) refere que um projeto nasce em réplica a um problema real, em que se procura colaborar para a solução de problemas, transformando ideias em ações. O projeto apontará o desenvolvimento de um conjunto de atividades a serem realizados para se obter um resultado, além de evidenciar os objetivos, os meios aproveitados para atingi-los, os recursos imprescindíveis e onde serão conseguidos e como serão analisados os resultados.

Durante a execução do projeto, os resultados poderão requerer atualizações no planejamento e mudanças nas linhas de base. Isso pode incluir mudanças nas durações esperadas para as atividades, mudanças na produtividade e na disponibilidade dos recursos e riscos imprevistos. Essas variações podem afetar o plano de gerenciamento do projeto ou os documentos do projeto e exigir uma análise detalhada e o desenvolvimento de respostas apropriadas de gerenciamento de projetos (PMBOK, 2013). 
Assim a gestão de projetos pode ser praticada em contextos diferentes, cada um com seus problemas específicos. Considerando a grande variedade de situações enfrentadas pelos profissionais de projetos, o paradigma de gerenciamento de projetos é definido no Guia PMBOK que reconhece a necessidade de se determinar quais processos, técnicas, ferramentas e habilidades são mais apropriados para um determinado projeto (PMI, 2013).

O principal objetivo do Guia PMBOK é identificar o subconjunto do conjunto de conhecimentos em gerenciamento de projetos que é amplamente reconhecido como boa prática. "Identificar" significa fornecer uma visão geral, e não uma descrição completa. "Amplamente reconhecido" significa que o conhecimento e as práticas descritas são aplicáveis à maioria dos projetos na maior parte do tempo e que existe consenso geral em relação ao seu valor e sua utilidade. "Boa prática" significa que existe acordo geral de que a aplicação correta dessas habilidades, ferramentas e técnicas pode aumentar as chances de sucesso em uma ampla série de projetos diferentes (VALLE et al., 2007).

As boas práticas definidas no Guia aplicam o gerenciamento de projeto por meio da integração de áreas de conhecimento, denominadas gerências de projetos. As gerências são compostas por uma série de processos, e incluem, entre outros, integração do projeto, aquisição, escopo, tempo, qualidade, cronograma, custos, recursos humanos, comunicações e riscos.

O gerente do projeto, juntamente com a equipe do projeto, orienta a execução das atividades planejadas e gerencia as diversas interfaces técnicas e organizacionais existentes. O gerente de projetos também deve gerenciar quaisquer atividades não planejadas e determinar o curso de ação apropriado, pois o processo de orientar e gerenciar o trabalho do projeto pode ser diretamente afetado pela área de aplicação do projeto (PMBOK, 2013).

Numa análise, referente a um caso de estudo sobre a implementação de um projeto utilizando o PMBOK como a metodologia, Gomes (2013) concluiu que a compreensão e a aplicação do PMBOK e a experiência adquirida, quando relacionadas de forma correta, foram sem dúvida fatores importantes para o sucesso de um projeto. Assim, se o gestor do projeto tiver essa correta compreensão do PMBOK, torna-se mais fácil lidar com os fatores críticos de 
sucesso dos projetos, tais como o planeamento e a atribuição das tarefas, o comprometimento da gestão de topo e a gestão das partes interessadas.

Para Spanhol e Santos (2009) as áreas de conhecimento e os grupos de processos propostas pelo guia possuem funções específicas, entretanto, interagem entre si e muitos dos processos ocorrem simultaneamente, em conjunto e podem exigir o envolvimento de diferentes áreas do conhecimento. Os aspectos citados vêm ao encontro de um projeto em EAD, pois este exige o detalhamento e acompanhamento de diversas atividades sequenciais e paralelas, bem como 0 envolvimento de uma equipe multidisciplinar.

Da aplicação prática deste conceito no ensino surge a Metodologia de Projetos, com o intuito de representar um determinado método didático utilizável em determinadas situações de ensino, sendo esse método instruído por diretrizes pedagógicas explícitas que constituíram uma Pedagogia de Projetos (MOURA; BARBOSA, 2011). Além destes conceitos surge também uma das metodologias utilizadas perante 0 contexto de aprendizagem ativa denominada Aprendizagem Baseada em Projetos (ABProj).

A origem da ABProj data por volta de 1900, quando John Dewey formulou um ideal pedagógico em que a aprendizagem se faz mediante o fazer, ou seja, o aprender fazendo, contextualizando o envolvimento do aluno na aquisição do conhecimento para a resolução de situações reais em projetos, ou seja, um ensino reflexivo. Como principais vantagens, esse método de aprendizagem favorece o trabalho em equipe e a união da teoria e prática e estimula a criatividade através do desenvolvimento de projetos, a partir da simulação de uma situação real (MASSON et al, 2012).

As recomendações relativas a formação do professor-reflexivo estão fortemente presentes nas discussões sobre formação e capacitação de professores e devem estar inseridas nos projetos de ensino realizados com base em uma concepção de planejamento e gestão de projetos educacionais.

O desafio da qualidade em projetos educacionais foi ponto de amplo diálogo na equipe haja vista em termos de capital intelectual, estabelecer métricas, parâmetros e indicadores do conhecimento é sempre uma tarefa complexa e até mesmo questionável, quantitativamente e qualitativamente. Um referencial de gestão de qualidade em EAD é o princípio criado pela University of 
Maryland University College (UMUC), que preconizam avaliar o currículo dos membros idealizadores do curso, avaliar o contexto e o comprometimento da instituição proponente, os recursos de aprendizado, o apoio ao aluno e o processo avaliativo.

No Brasil o referencial que está sendo utilizado é baseado em determinações específicas para EAD através da Lei de Diretrizes e Bases da Educação, regulamentada pelo Decreto 5.773 de junho de 2006 e das Portarias Normativas 1 e 2 de 11 de janeiro de 2007, que usam para efeito de controle de qualidade em processos de EAD a concepção de ensino-aprendizagem, os sistemas de comunicação, o material didático, a avaliação, a equipe, a infraestrutura de apoio, a gestão e a sustentabilidade financeira.

No que tange às questões de aprendizagem, é importante ressaltar, como aponta Vygotsky, que o homem cria instrumentos para transformar a natureza e a si mesmo. Dessa forma, pode-se refletir que os projetos educacionais de EAD por sua não linearidade assemelham-se aos padrões de funcionamento da mente humana, o que pode estreitar o distanciamento entre o conhecimento e o ser docente, já que o contato deste último com o conhecimento ocorre também de forma não linear.

Em várias situações na GP se evidencia o uso colaborativo dos meios de mediação e mediatização na realização de atividades que envolvem o planejamento, a execução das ações previstas e monitoração das atividades, evidenciando compromisso mútuo e interdependência entre todos os participantes. A programação de cada fase e cada processo resulta do debate entre os integrantes para negociar espaços de disseminação de informações relevantes e compor o roteiro, com o cuidado de preservar o alcance dos objetivos do encontro e os propósitos do projeto.

Monitorar e controlar o trabalho do projeto é um processo de acompanhamento, análise e registro do progresso para atender aos objetivos de desempenho definidos no plano de gerenciamento do projeto. O principal benefício deste processo é permitir que as partes interessadas entendam a situação atual do projeto, os passos tomados, e as previsões do orçamento, cronograma (PMBOK, 2013). 
Dessa forma, o gerenciamento da mediação pedagógica na EAD, inferido como um processo de produção do conhecimento que envolve suportes mediadores, tecnológicos ou não, procedimentos interativos e relações entre os stakeholders, encontra na teoria sociointeracionista, construtos relevantes para uma análise mais apurada da mediação da aprendizagem em AVA.

Pautado nesta ideia, Lévy (1999) também apresenta o conceito de inteligência coletiva, baseando-se no conjunto de funções cognitivas compartilhados mutuamente entre sujeitos e instituições que pode ser ampliado com o uso das tecnologias e a comunicação em rede. Diante deste fato, averíguase que a sociedade da informação não é um modismo e sim um fenômeno global, de dimensões político-econômicas, que precisa ser gerenciado, de forma que o conhecimento seja transformado em recurso. Para este autor, gestão é imaginar, experimentar e promover estruturas de organizações e estilos de decisão orientados para o aprofundamento da democracia.

No sentido educacional, de acordo com Moura e Barbosa (2011), projetos educacionais são aqueles elaborados para: implantar novas metodologias de ensino; pesquisar sobre resultados de trabalhos pedagógicos; produzir recursos didáticos e orientações pedagógicas; ampliar ou implantar novos cursos; implantar novos laboratórios de ensino; capacitar docentes no planejamento de gestão de projetos e qualificar docentes em programas de especialização e pós-graduação.

Para esses autores podem-se identificar projetos dirigidos para as mais diversas finalidades: reforma do sistema educacional em seus diversos níveis; inclusão de novas tecnologias na educação; capacitação de professores e gestores; criação de novos cursos em diferentes níveis e modalidades; desenvolvimento do ensino; desenvolvimento do sistema de avaliação; implantação de metodologias por meio de projetos.

Nesta visão, a gestão de projetos educacionais e de capacitação profissional para o uso da TDIC como recurso pedagógico envolve a renovação permanente e progressiva dos saberes para um novo horizonte de trabalho. As tecnologias beneficiam o acesso à informação, estilos de conhecimento e compartilhamento de documentos entre indivíduos. Nesse sentido, o fluxo informacional convertido em fluxo de conhecimento, através das tecnologias modifica os objetivos da ação 
educativa mediante uma aprendizagem cooperativa através da EAD e seu potencial interativo conferindo um novo estilo de pedagogia.

No contexto da estruturação dessa visão sistêmica, obrigatória no desenvolvimento de um processo profissional e sustentável de gestão, cresce a importância de estruturas para viabilizar projetos educacionais em EAD e prover os elementos que vão dar suporte a esse tipo de gestão.

Um gerenciamento eficaz pode ser baseado no Guia PMBOK, mas o PMI preconiza que a equipe de gerenciamento de projetos entenda e use o conhecimento $\mathrm{e}$ as habilidades de pelo menos outras quatro áreas de especialização: (1) conhecimentos, normas e regulamentos da área de aplicação; (2) entendimento do ambiente do projeto; (3) conhecimento e habilidades de gerenciamento geral; e (4) habilidades interpessoais. Cabe à equipe do projeto aplicar os conhecimentos que julgar necessários, de modo a se ajustar ao projeto específico e à organização (SAMPAIO, 2011).

Uma das áreas de conhecimento do Guia PMBOK é a de Gerenciamento da Integração do projeto, que trata da coordenação de todos os processos e das atividades necessárias para identificar, definir, combinar, unificar e coordenar as atividades dos grupos de processos de gerenciamento. Quanto às contribuições na oferta de educação tecnológica, esta área direcionando a todos os detalhes do que fazer, como fazer, o que será entregue ou não, quem é o responsável, quais as infraestruturas, logística, papéis, responsabilidade, comunicação, risco, partes interessadas, aquisições, etc., corroborando e escriturando todas as etapas que conduzem para gerenciar com sucesso as expectativas das partes interessadas e atender aos requisitos (COSTA et al., 2015).

A área de gerenciamento do escopo do projeto contempla tudo que deve ser atendido para o sucesso do projeto. O gerenciamento do escopo inclui os processos necessários para assegurar que o projeto detém todo o trabalho necessário, e apenas o necessário, para terminar o projeto com sucesso (PMI, 2013). Ochner (2006) cita que existem dois tipos de escopo: o explícito é aquele descrito em documento, controlável por processos; e o implícito está associado às expectativas e desejos dos clientes, não há processo formal, está vinculado à comunicação. 
O escopo detém atividades gerenciais presentes nas etapas iniciação, planejamento e controle de um projeto, relacionadas à gestão das entregas previstas. Toda entrega é algo que se pode medir, é tangível e verificável. Um projeto pode ter uma ou várias entregas, de variadas naturezas e características como: um software, um novo produto, uma análise de mercado, uma implantação de sistemas, a execução de um plano de educação continuada (RAPHAEL et al., 2006).

Em uma oferta para projetos educacionais e tecnológicos gerenciar o tempo é a chave para analisar quando e como o projeto estará finalizado seguindo uma linha base. Nesta área busca-se elaborar e estruturar um cronograma com início e término de cada atividade, ações a serem realizadas e quais os recursos envolvidos, visando monitorar o andamento das atividades para atualização do seu progresso, como também, informar se as entregas serão finalizadas no tempo estimado, dando feedbacks às partes interessadas do projeto (COSTA et al., 2015).

As atividades de gerenciamento da qualidade do projeto determinam as políticas e padrões de qualidade, objetivos, responsabilidades e sua implantação e podem demandar algumas técnicas e ferramentas para o planejamento e controle tais como: gráficos de controle, fluxogramas, inspeções, auditorias, estudo de probabilidades, análise por amostragem estatística, análise de tendências, distribuição normal e triangular, checklists (RAPHAEL et al., 2006).

Diversas atividades gerenciais estão presentes nas etapas planejamento e controle de um projeto, relacionadas à execução e conclusão do projeto dentro do orçamento previsto. Constituir um cenário detalhado de ações, prioridades funcionais, estratégicas e de custos, pode ser a diferença entre um projeto educacional em EAD viável economicamente ou de prejuízo institucional.

O PMBOK (2013) também aborda os tipos de custos, depreciação de bens, técnicas para cálculos de valores de contingências e reservas, bem como, índices para avaliação de progresso do projeto. Quanto às técnicas para elaboração de estimativas de tempo e custos, menciona: por analogia (a estimativa é realizada efetuando-se a associação com dados históricos similares), a paramétrica (utiliza relação matemática entre dados históricos e outras variáveis) e a bottom-up (de baixo para cima). 
Em outro aspecto, o gerenciamento dos custos do projeto preocupa-se principalmente com o custo dos recursos necessários para completar as atividades do projeto e deve considerar também o efeito das decisões de projeto no custo recorrente subsequente ao uso, manutenção e suporte do produto, serviço ou resultado do projeto. Em projetos de menor duração, os processos de estimar os custos e determinar o orçamento são interligados tão firmemente que são vistos como um processo único que pode ser realizado por uma pessoa num período de tempo relativamente curto (PMI, 2013)

O envolvimento e a participação dos membros da equipe desde o início agregam seus conhecimentos durante o planejamento e fortalece o compromisso com o projeto. A equipe de gerenciamento de projetos é um subconjunto da equipe do projeto e é responsável pelas atividades de gerenciamento e liderança, como iniciação, planejamento, execução, monitoramento, controle e encerramento de várias fases. Esse grupo também pode ser chamado de equipe principal, equipe executiva ou equipe de liderança. Para projetos menores, as responsabilidades de gerenciamento podem ser compartilhadas por toda a equipe ou administradas exclusivamente pelo gerente de projetos (BONFIM et al., 2012).

Envolver as partes interessadas no início do projeto aumenta a probabilidade de aceitação das entregas do projeto, haja vista que as partes interessadas são utilizadas para mapear o escopo do projeto e os requisitos do produto. A maioria dos projetos tem um grande número de partes interessadas. Como o tempo do gerente de projetos é limitado e precisa ser usado com a maior eficiência possível, essas partes interessadas devem ser classificadas de acordo com o interesse, a influência e o envolvimento no projeto. Isso permite que o gerente de projetos se concentre nos relacionamentos necessários para garantir o sucesso do projeto (PMI, 2013).

O Gerenciamento das partes interessadas do projeto inclui os processos exigidos para identificar todas as pessoas, grupos ou organizações que podem impactar ou serem impactados pelo projeto, analisar as expectativas das partes interessadas e seu impacto no projeto, além de desenvolver estratégias de gerenciamento apropriadas para o envolvimento eficaz das partes interessadas nas decisões e execução do projeto. Nesta área também se concentra na comunicação contínua com as partes interessadas para entender suas 
necessidades e expectativas, abordando as questões conforme elas ocorrem, gerenciando os interesses conflitantes e incentivando o comprometimento das partes interessadas com as decisões e atividades do projeto (PMI, 2013).

O gerenciamento das comunicações do projeto inclui os processos necessários para assegurar que as informações do projeto sejam planejadas, coletadas, criadas, distribuídas, armazenadas, recuperadas, gerenciadas, controladas, monitoradas e finalmente dispostas de maneira oportuna e apropriada. Os gerentes de projetos passam cerca de $90 \%$ do tempo se comunicando com os membros da equipe e outras partes interessadas do projeto, internas ou externas à organização. A comunicação eficaz cria uma ponte entre os diversos stakeholders do projeto, que podem ter diferenças culturais e/ou organizacionais, níveis de conhecimento distintos, e diversas perspectivas e interesses que podem impactar ou influenciar a execução ou resultado do projeto (COSTA et al., 2015).

Para Kerzner (2011) o gerenciamento das comunicações é vital para o sucesso de um projeto, uma vez que se a comunicação for realizada de forma eficaz no projeto, ela garantirá que as informações certas cheguem para a pessoa certa, no momento certo e de maneira rentável e sem riscos.

De acordo com Salles Júnior et al (2010), a palavra risco está diretamente relacionada à incerteza, um acontecimento futuro, incerto, que pode tanto ser positivo quanto negativo. Risco também pode ser entendido como a falta de informação sobre o acontecimento futuro. O gerenciamento de risco se antecede aos riscos para minimizar ou cessá-los por meio de identificação dos mesmos, análise, planos de ação, monitoramento e controle.

Para riscos negativos, são usadas as estratégias: prevenir (adequar o projeto para minimizar ou eliminar riscos, esclarecer informações/requisitos do projeto e melhorar a comunicação), transferir (transferir o risco para outra parte observando que o risco não é cessado) e mitigar (diminuir a probabilidade do risco até um impacto aceitável). Para riscos positivos, as estratégias usadas são: explora-los, compartilha-los com terceiros para que possam melhora-los e melhorar (fortalecer a probabilidade do impacto). É importante o cuidado na identificação e análise dos riscos para a eficiência das ações assim como o 
monitoramento e controle periódico para atingir o êxito do resultado final do projeto de forma controlada (PMBOK, 2013).

A gestão de projetos em ambientes educacionais ocorre simultaneamente a muitos outros projetos, e nem sempre contempla um planejamento estratégico adequado. Frente a este contexto, devemos lembrar que os riscos, as dificuldades e as efetividades na realização de projetos educacionais têm sido constantes no âmbito acadêmico, sempre repletos de questionamentos e hipóteses em busca da viabilidade de elaboração de produtos e projeção de conhecimentos através de recursos virtuais.

Para se institucionalizar práticas padronizadas, de forma que a organização mantenha a aplicação de modelos de projetos, processos estruturados e de uso contínuo ou repetido, pacotes de ferramentas e modelos de projetos devem ser aplicados, corroborando esta ideia com algo não comum nas aplicações de gestão de projetos educacionais (PATAH; CARVALHO, 2012).

Dessa forma, devemos estar dispostos a acreditar que a GP pode ser uma ferramenta poderosa para o sucesso não somente do projeto em andamento, mas para a continuidade do empreendimento como um todo. Portanto, a ênfase no Guia PMBOK aliado com a disseminação das metodologias e práticas de gerenciamento de projetos torna evidente a vantagem competitiva que poderá ser obtida em se aplicar essas duas técnicas no desenvolvimento de projetos educacionais. 


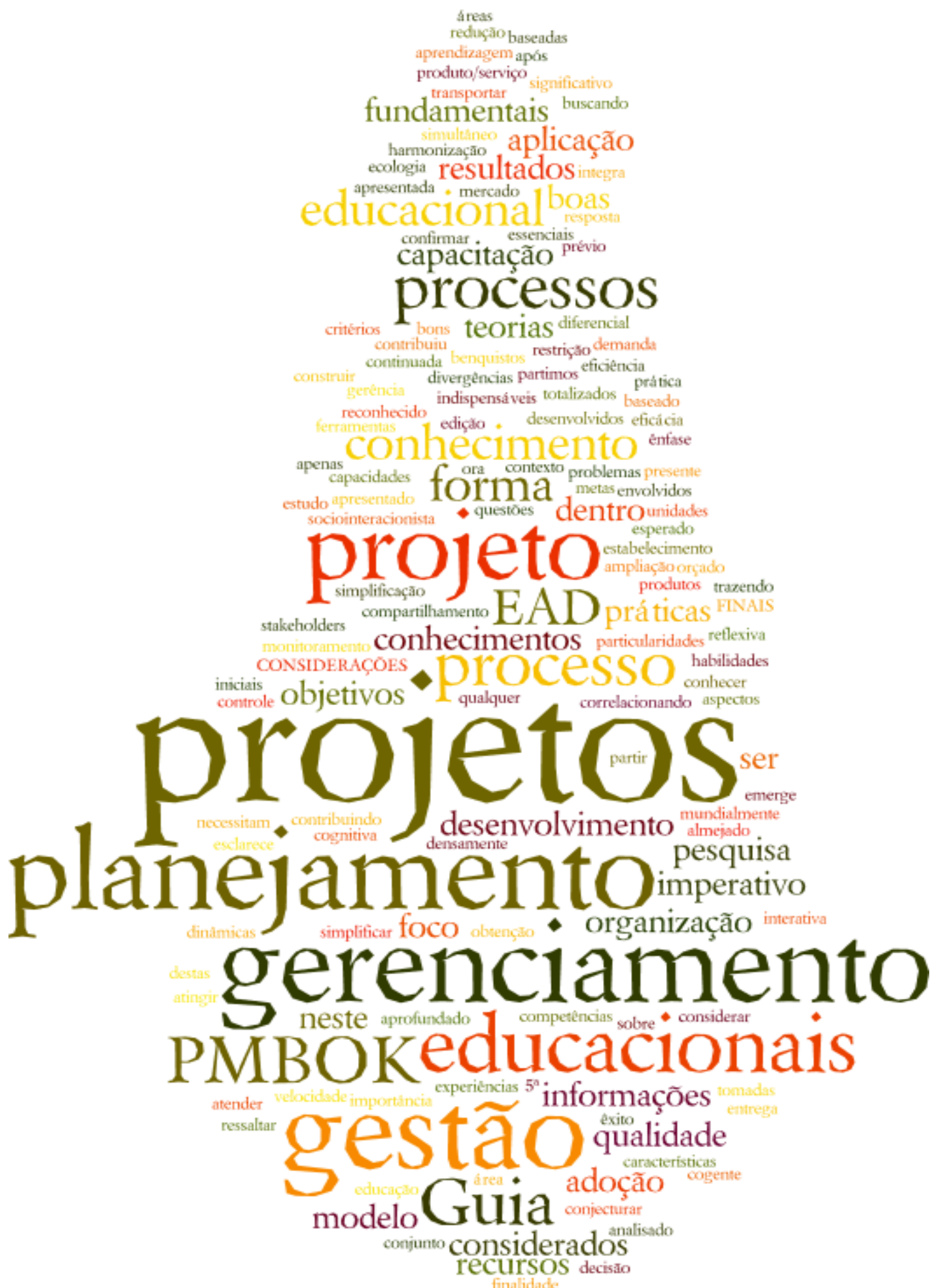

CONSIDERAÇÕES FINAIS 


\section{CONSIDERAÇÕES FINAIS}

Para responder questões como: "Como planejar e gerenciar projetos educacionais?", "Como conjecturar um curso baseado em um modelo de gerenciamento reconhecido mundialmente?", foi cogente um estudo aprofundado sobre o tema de gestão de projetos, buscando conhecer as características e particularidades dos projetos educacionais correlacionando com as ferramentas de gestão do Guia PMBOK 5ª edição.

A proposta de escrever uma tese de doutorado sobre GP na área educacional visando o aperfeiçoamento docente através de um curso a distância foi fundamentada na necessidade de material de referência voltado para a formação de competências em planejamento e gestão de projetos educacionais, vislumbrando atender as demandas de mercado vinculadas aos avanços andragógicos, tecnológicos e gerenciais.

A produção desta pesquisa foi tratada como um projeto baseado em conceitos e metodologia do modelo de planejamento e gestão aqui apresentado. Por se tratar de um projeto educacional específico, envolvendo, na maior parte do tempo, apenas as autoras, alguns componentes dos aspectos utilizados para construção das diretrizes de gerenciamento de projetos em EAD foram adaptados às características do empreendimento.

Desde a década de 90, tem havido grande discussão temática em torno da GP, devido a sua capacidade de ampliar a competitividade de empreendimentos em um mercado tão globalizado e disputado. Este conceito de gerenciamento vislumbrou o funcionamento de atividades com foco na sequência de ações que fazem com que os produtos cheguem a seus clientes com qualidade e eficiência. $\mathrm{Na}$ atualidade, a GP é bastante aceita nos meios acadêmicos e profissionais, principalmente quando aplicadas a investimentos vinculados ao uso de TDIC.

Neste projeto, o Guia PMBOK foi utilizado como método de inspiração haja vista que a experiência e o discernimento da equipe foram fundamentais para a escolha, em cada situação, do que deveria ou não ser aplicado. As boas práticas são caracterizadas justamente pelo seu uso de acordo com a demanda específica de cada projeto. 
Todavia, hábitos de bons planejamentos, gestão, controle, acompanhamento e avaliação são raros nos projetos educacionais. Ficou compreendido, após a pesquisa, que um aprofundamento na compreensão desta questão, pode contribuir para a criação ou consolidação de uma cultura de projetos na área educacional que estamos focalizando.

O cenário das atividades que embasaram esse projeto educacional para planejamento e gerenciamento de um curso de capacitação de profissionais no uso de TDIC como recursos pedagógicos apresentou muitas demandas, a começar pela harmonização das teorias, não somente administrativas necessárias para este tipo de empreendimento, mas também com as teorias sócioeducacionais, igualmente importantes.

A ideia de trabalhar com projetos como recurso didático na elaboração de um curso, justificou-se pela complexidade da proposta, adicionada a diferentes pontos de vista dos envolvidos no processo, desde as fases da intencionalidade da pesquisa, ao planejamento da metodologia, execução das etapas e julgamento das atividades visando a promoção de uma aprendizagem significativa, através das tecnologias.

Durante todo planejamento deste projeto foi considerado o conjunto de habilidades e competências recomendadas aos gestores idealizadores e aos professores participantes do curso. Um dos pressupostos iniciais foi considerar situações reais relativas ao contexto de vida profissional de cada integrante, no sentido de permanecerem focados no objeto central do projeto em desenvolvimento.

Outros pressupostos utilizados no gerenciamento deste projeto foram: definição de um período de tempo limite para concretização do projeto; a escolha do tema em negociação coletiva; o objetivo final e os temporários; a definição metodológica específica para cada contexto educativo e a socialização dos resultados obtidos.

Os referenciais utilizados permitiram fazer contrapontos entre teorias no sentido de melhor fundamentar a qualidade do projeto. Buscar a articulação de pressupostos de alguns teóricos da aprendizagem com o uso de tecnologias e processos de aprendizagem na EAD com intuito de aperfeiçoar o gerenciamento 
do projeto amplia o sentido prático de muitos gestores que ficam restritos à aquisição de aparatos tecnológicos que, na verdade, não serão mediadores de trocas socializadoras, de debates e de uma aprendizagem mais colaborativa.

Abordar as teorias sociointeracionista, da ecologia cognitiva e a epistemologia da prática reflexiva com concepções diferentes acerca dos processos educacionais, consiste numa rica experiência investigativa para assegurar o gerenciamento do projeto proposto. Ao investigar estas teorias e vinculando-as gestão de projetos educacionais destacou-se: o impacto da mediação e de intermediação de informações e conteúdos nos AVA's; o papel desempenhado pelo gestor, cuja reflexão sobre sua prática educativa e compromisso conduz e incentiva o aluno a estabelecer trocas sociais e cognitivas; o potencial de interatividade das TDIC como instrumento de ensino-aprendizagem que, em espaço de mediação virtual, reconfigura a prática docente visando à habilitação emancipadora do aprendiz; a dimensão dada ao desenvolvimento cognitivo do aprendiz como sujeito ativo como aspecto relevante para a qualidade do processo.

Em simultâneo a gestão do conhecimento e as tecnologias, emerge a importância da gerência de projetos, que consiste na aplicação de informações, habilidades e conhecimentos com foco no êxito de um conjunto de metas estabelecidas. A gestão de projetos demonstrou vantagens dinâmicas no planejamento de projetos em EAD, contribuindo para a identificação, desenvolvimento e organização das informações, harmonização das comunicações, troca de experiências, formação de grupos, redução de divergências e compartilhamento de problemas e soluções.

Em função da aplicação e do desenvolvimento, ora apresentado, a resposta à questão de pesquisa esclarece: $\mathrm{A}$ adoção das boas práticas preconizadas no Guia PMBOK demonstraram transportar eficiência, eficácia e efetividade no planejamento de projetos de capacitação de profissionais no uso de TDIC como recursos pedagógicos, trazendo variáveis baseadas em parâmetros de áreas do conhecimento e processos de gerenciamento de forma interativa e favorecendo a entrega do produto/serviço com qualidade, no tempo esperado e no custo orçado.

Para se atender diretamente aos objetivos deste projeto, foi imperativo simplificar o processo de gerenciamento. A simplificação ocorreu após o 
julgamento prévio dos processos que poderiam ser considerados fundamentais e indispensáveis. É significativo enfatizar que em diferentes projetos educacionais, apenas os processos considerados decisivos necessitam ser totalizados, uma vez que a velocidade do planejamento integra bons resultados ao projeto.

Cada área de conhecimento do Guia PMBOK teve, em seus processos, a organização de acordo com as demandas e conhecimentos do projeto e dos gestores, com ênfase no planejamento educacional. O detalhamento conceitual e operacional foi analisado de forma a orientar os aspectos essenciais para 0 planejamento de um projeto em EAD dentro de um contexto gerencial norteada pelo modelo das boas práticas em gestão de projetos.

O planejamento por unidades de aprendizagem, o monitoramento, o controle e os critérios de qualidade estabelecidos foram fundamentais para as tomadas de decisão no gerenciamento. O estabelecimento das atividades predominantes do projeto educacional e sua finalidade principal fizeram que os produtos fossem desenvolvidos dentro do que era almejado pelos stakeholders, sendo benquistos sem qualquer restrição.

Vale ressaltar que ao considerar a gestão de um projeto educacional em EAD com foco em capacitação de recursos tecnológicos, partimos da necessidade de vincular as teorias sociointeracionista, da ecologia cognitiva e a epistemologia da prática reflexiva ao processo de planejamento. A partir destas teorias foram traçadas estratégias que conduziram o processo de forma a atingir os objetivos educacionais envolvidos, gerando um diferencial neste gerenciamento.

Tal cenário parece confirmar uma demanda de mercado: a ampliação de modelos de gestão de educação continuada e a distância. $O$ imperativo do gerenciamento de projetos educacionais para obtenção de resultados no presente para construir as capacidades e competências necessárias para competir no futuro, são indicadores de sucesso neste processo, e para isto, a adoção da metodologia de gerenciamento de projetos do Guia PMBOK contribuiu densamente.

A tessitura dos conhecimentos emergidos e constituídos neste projeto permitiu vislumbrar novas oportunidades de diálogos transdisciplinares e aproximação com o aprender, com o criar, com o gerir, enfim, com a possibilidade de propostas educacionais que buscam lidar com o processo dinâmico, contínuo e 
pluridimensional do desenvolvimento docente e no encaminhamento de situações de aprendizagem. Por que como pesquisadora epistemologicamente curiosa e adepta das memórias de Paulo Freire, considero que "por estar pensando criticamente a prática de hoje ou de ontem, será sempre possível melhorar a próxima prática”. 


\title{
10 REFERÊNCIAS
}

ABED, CENSO E. A. D. BR. Relatório analítico da aprendizagem a distância no Brasil 2014. Person Education do Brasil. Associação Brasileira de Educação a Distância. São Paulo-2015, 2015.

\begin{abstract}
ALENCASTRO, L. H. Concepções de estudantes sobre os projetos de aprendizagem no ensino superior. Dissertação (mestrado) - Universidade Federal do Paraná, Setor de Educação, Programa de Pós-Graduação em Educação. 2010.
\end{abstract}

ALMEIDA, M.E.B. Educação a distância na internet: abordagens e contribuições dos ambientes digitais de aprendizagem. Educação e Pesquisa, São Paulo, v.29, n.2, p. 327-340, jul./dez. 2003.

ALVES, J.C; PEREIRA, P.C; PEREIRA, R. S. Ambientes virtuais e mídias de comunicação, abordando a explosão das mídias na sociedade da informação e seu impacto na aprendizagem o uso do WhatsApp como plataforma de mlearning. Revista Mosaico, v. 6, n. 1, p. 29-41, 2015.

ANDRADE, A. F; VICARI, R. M. Construindo um ambiente de aprendizagem a distância inspirado na concepção sociointeracionista de Vygotsky. In: SILVA, Marco (Org.). Educação online: teorias, práticas, legislação, formação corporativa. 3. ed. São Paulo: Ed. Loyola, 2011.

ANDRADE, S. C; TAIT, T. F. C. Uma aplicação do guia PMBOK na gestão de projetos de software. Revista Brasileira de Computação Aplicada, v. 4, n. 1, p. 2-11, 2012.

APPOLINÁRIO, F. Metodologia da ciência: filosofia e prática da pesquisa. Thomson, 2006.

ANJOS, M. U; ANDRADE, C. C. A relação entre educação e cibercultura na perspectiva de Pierre Lévy. Revista Eletrônica Latu Sensu, v. 5, p. 1-12, 2008.

ARAÚJO, E. T; BOULLOSA, R. Dicas técnicas para vivências de RS. Documento técnico do MBADRS. Salvador: CIAGS/UFBA, 2007.

ARNOLD, S. B. Planejamento em Educação a Distância. In: ARNOLD, S. B. T; MOREIRA, M (Orgs). Educação a distância. Belo Horizonte: PUC Minas Virtual, 2002.

ASCHER, P; GUIMARÃES, A. Monitoramento e avaliação de projetos:

métodos e experiências / Ministério do Meio Ambiente, Secretaria de Coordenação da Amazônia, Programa Piloto para a Proteção das Florestas Tropicais do Brasil, 2004. 
BACCARINI, D. The logical framework method for defining project success. Project Management Journal, v. 30, n. 4, p. 25-32, 1999.

BARBOSA, C. M. A. M. A aprendizagem mediada por TIC: interação e cognição em perspectiva. Revista Brasileira de Aprendizagem Aberta e a Distância. São Paulo: ABED. N. XI, setembro, p. 95, 2012.

BARBOSA. E.F; MOURA. D.G; NAGEM. Contribuição do método de projetos para a inclusão das tecnologias da informação na escola. Revista Tecnologia Educacional, Rio de Janeiro: Associação Brasileira de Tecnologia Educacional, v. 19, n. 156, p. 40-54, 2002.

BASSIS, N. F. Gerência de Projetos aplicada à Gestão do Conhecimento. Brasport, 2009.

BELLONI, M. L. Educação a Distância. 5. ed. Campinas, SP: Autores Associados, 2009.

BERNARDI, M; DAUDT, S. D; BEHAR, P. A. Domínio da gestão em educação a distância: foco na coordenação de cursos. In. Competências em Educação a Distância. Porto Alegre: Penso, p. 135-147, 2013.

BOMFIN, D. F; DE ÁVILA NUNES, P. C; HASTENREITER, F. Gerenciamento de projetos segundo o Guia PMBOK: desafios para os gestores. Revista de Gestão e Projetos, v. 3, n. 3, p. 58-87, 2012.

BOTO, C. Um credo pedagógico na democracia escolar: algum traçado do pensamento de John Dewey. Rev Educação Porto Alegre - RS, ano XXIX, n. 3 (60), p. 599 - 619, Set./Dez. 2006.

BRASIL, MEC. Referenciais de qualidade para Educação superior a distância. Secretaria de Educação a Distância. Ministério da Educação. v. 15, 2007.

BRASIL. Decreto 5.622, de 19 de dezembro de 2005. Regulamenta o artigo 80 da Lei no 9.394, de 20 de dezembro de 1996, que estabelece as diretrizes e bases da educação nacional. Diário Oficial [da] República Federativa do Brasil. Brasília, DF, 20 dez. 2005.

BROCKE, J. VON; ROSEMANN, M. Manual de BPM: gestão de processos de negócio. Porto Alegre: Boookman, 2013.

CARDOSO, Z. C. S et al. Perfil dos acadêmicos do centro de educação a distância/Cead-Unimontes e a preferência pelo material didático impresso quanto a disposição do texto e o entendimento da leitura. Anais do SIED: EnPED-ISSN 2316-8722, v. 1, n. 1, 2012. 
CASTRO, J. M; LADEIRA, E. S. Gestão e planejamento de cursos a distância $(E a D)$ no Brasil: um estudo de casos múltiplos em três instituições de ensino superior. Gestão \& Planejamento-G\&P, v. 10, n. 2, 2010.

CHAVES, M. C. S. Fatores importantes para desenvolvimento de cursos on-line. [Online]. Available: http:// cdchaves.sites.uol.com.br/fatores_desenvolvimento.htm. Rio de Janeiro, 2007.

CLELAND, D. I; IRELAND, L. R. Gerenciamento de projetos, revisão técnica. 2. Edição, Rio de Janeiro. 2007.

CONTRERAS, J. A autonomia de professores. Cortez, 2002.

COSTA, C. M. A et al. As boas práticas do PMBOK® e as contribuições para o repensar do ensino da saúde. Gestão e Saúde, v. 6, n. 2, p. Pag. 1968-1981, 2015.

COTTA, R. M. M; COSTA, G. D; MENDONÇA, E. T. Portfólio reflexivo: uma proposta de ensino e aprendizagem orientada por competências. Revista Ciência \& Saúde Coletiva, v. 18, n. 6, p. 1847-1856, 2013.

CRONIN, J; TAYLOR. S.A. Mensurando Qualidade de Serviços. In: BATESON, J.E.G.; HOFFMAN, K.D. Marketing de Serviços. $4^{\circ}$ ed. Porto Alegre: Bookman, 2003, p. 465-478.

CUNHA, E. S. F. Trabalho Docente a Distância: flexibilização e/ou precarização? Dissertação (Mestrado) Universidade de Uberaba - UNIUBE-MG. Programa de Mestrado em Educação. 304 p. 2015.

DA CUNHA, M. V. John Dewey: a utopia democrática. DP \& A, 2001.

DA SILVA ABBAD, G. Educação a distância: o estado da arte e o futuro necessário. Revista do Serviço Público, v. 58, n. 3, p. 351-374, 2014.

DE ALMEIDA, M; MENDES, M; BANCOVSKY, R. O Processo de Gestão de Projetos em EAD: Tecendo Algumas Considerações a Partir do Projeto "Gestão Escolar e Tecnologias". In: RIBIE-VIII Congresso Iberoamericano de Informática Educativa, San Jose. 2006.

DE CARVALHO, R. A; BONDIOLI, A. C. V. O ensino a distância como ferramenta de inclusão social: desafios sociais e tecnológicos. Brasil Para Todos-Revista Internacional, v. 2, n. 1, p. 91-95, 2015.

DEWEY, J. Como pensamos - como se relaciona o pensamento reflexivo com o processo educativo: uma reexposição. São Paulo: Companhia Editora Nacional, 1959.

DINSMORE, P. C; CAVALIERI, A. Como Se Tornar Um Profissional Em Gerenciamento de Projetos. Rio de Janeiro: Qualitymark, 3 ed., 2009. 
ELIASQUEVICI, M.K; PRADO JUNIOR, A.C. O papel da incerteza no planejamento de sistemas de educação a distância. Educação e Pesquisa, São Paulo, v. 34, n. 2, maio/ago. 2008.

ENAP. Introdução ao gerenciamento de projetos. Escola Nacional de Administração Pública; Brasília: Ed ENAP, 2014.

FINOCCHIO JÚNIOR, J. Project Model Canvas: gerenciamento de projetos sem burocracia. Elsevier Brasil, 2014.

FRANÇA, G. O design instrucional na educação a distância: John Dewey como uma referência metodológica. São Paulo: Editora Esfera, 2007.

FRANCIOSI, B et al. Modelando ambientes de aprendizagem a distância baseado no uso de mídias integradas: um estudo de caso. In: Anais do VIII Congresso Internacional de Educação a Distância. Brasil. 2001.

GIL, A. C. Como Elaborar Projetos de Pesquisa, Atlas 5aㅡ. 2010.

HARROFF, P.A.; VALENTINE, T. Dimensions of Program Quality in Web-Based Adult Education. The American Journal of Distance Education, v. 20, n.1, p.722, 2006.

HERMENEGILDO, J. L. S; RIBAS, J. C. C. Educação a distância no CEFET-SC: desafios e possibilidades na gestão do programa Universidade Aberta do Brasil. V Congresso brasileiro de ensino superior a distância; 60 seminário nacional ABED de educação a distância, 2008.

INSTITUTO FONTE. Fundação Itaú Social. Elaborar um plano e monitoramento e avaliação. Coleção caminhos para o desenvolvimento de organizações da sociedade civil. Novembro de 2012.

KERZNER, H. Gerenciamento de Projetos: Uma abordagem sistêmica para planejamento, programação e controle. São Paulo: Blucher, 2011.

KLOPPENBORG, T. J; TESCH, D; MANOLIS, C. Project success and executive sponsor behaviors: Empirical life cycle stage investigations. Project Management Journal, v. 45, n. 1, p. 9-20, 2014.

LAPA, A; PRETTO, N. L. Educação a distância e precarização do trabalho docente. Em Aberto, v. 23, n. 84, 2010.

LEE, W. W; OWENS, D. L. Multimedia Based Instructional Design. San Francisco: Jossey-Bass, 2000.

LEMAK et al. Technology, transactional distance and instructor effectivenes: An empirical investigation. Academy of Management \& Education, 4(2), 150, 2005. 
LENZI, G. K. S. Diretrizes para a gestão de projetos de cursos de capacitação na modalidade de educação a distância. 2010. Tese de Doutorado.

Universidade Federal de Santa Catarina, Centro Tecnológico, Programa de PósGraduação em Engenharia e Gestão do Conhecimento, Florianópolis. 2010.

LESSA, S. C. F. Os reflexos da legislação de educação a distância no Brasil. Revista Brasileira de Aprendizagem a Distância, v. 10, 2011.

LÉVY, P. Cibercultura. São Paulo: Editora 34, 2010.

LÉVY, P. Tecnologias da inteligência. São Paulo: Editora 34, 2001.

LÉVY, P. O que é o virtual? São Paulo: Editora 34, 2003.

LOPES, R. O. A. Projetos: Deliberados ou Emergentes: As Práticas em Gerenciamento de Projetos e as Estratégia empresarial. 2010. (Dissertação) Mestrado em Administração. Fundação Getúlio Vargas. Rio de Janeiro, RJ, Brasil. 2010.

MAIA, C; J. MATTAR. ABC da EaD: a Educação a Distância hoje. 1. ed. São Paulo: Pearson. 2008.

MARTINS, R. X et al. Porque eles desistem? Estudo sobre a evasão em cursos de licenciatura a distância. In: CONGRESSO BRASILEIRO DE ENSINO SUPERIOR A DISTÂNCIA, 10, 2013, Belém. Anais...Belém: UNIREDE, 2013. p. 1-15.

MASSON, T. J et al. Metodologia de ensino: aprendizagem baseada em projetos (pbl). In: Anais: CONGRESSO BRASILEIRO DE EDUCAÇÃO EM

ENGENHARIA. Belém. UFPA. 2012.

MENCHACA, P; BEKELEB, T.A. Learner and instructor identified success factors in distance education. Distance Education. v. 29, n. 3, p.231-252, 2008.

MERCADO, L. P. L; DE ALMEIDA FIGUEIREDO, L. K; DE BULHÕES JOBIM, D. R. Formação de tutores do curso piloto de administração a distância da Universidade Aberta do Brasil. Debates em Educação, v. 1, n. 1, 2009.

MILL, D et al. Gestão da Educação a Distância (EaD): noções sobre planejamento, organização, direção e controle da EaD. Vertentes (UFSJ), v. 35, n. 1, p. 9-23, 2010.

MOODLE. A Free Open Source Course Management System for Online Learning, 2015.

MOORE, M.; KESRSLEY, G. Educação a distância: uma visão integrada. São Paulo: Thomson Learning, 2007. 398 p.

MORAN, J. M. O ensino superior a distância no Brasil. Educação \& Linguagem, v. 12, n. 19, p. 17-35, 2009. 
MOREIRA, B. C. M et al. Gestão acadêmica na educação a distância: desafios e práticas. X Colóquio Internacional sobre Gestión Universitária em América del Sul. Mar Del Plata. Argentina. 2010.

MOURA, D.G; BARBOZA, E.F.B. Trabalhando com projetos: planejamento e gestão de projetos educacionais. 7.Ed. Petrópolis, RJ: Vozes, 2013.

NOVAK, R.J. Benchmarking Distance Education. New Directions for Higher Education, n.118, p. 79-92, Summer 2002.

OCHNER, J. Gerência de projetos: uma comparação entre o PMBOK e XPM. 2006. 49 p. Monografia (Graduação em Ciência da Computação) - Universidade Federal de Lavras, Lavras, 2006.

PAPKE-SHIELDS, K.E., BEISE, C., \& QUAN, J. Do project managers practice what they preach, and does it matter to project success? International Journal of Project Management, 28(7), pp. 650-662, 2010.

PATAH, L. A; DE CARVALHO, M. M. Métodos de gestão de projetos e sucesso dos projetos: um estudo quantitativo do relacionamento entre estes conceitos. Revista de Gestão e Projetos, v. 3, n. 2, p. 178-206, 2012.

PASCUAL, M.D.F et al. Validation of a Spanish version of the Distance Education Learning Environments Survey in Spain. Learning Environments Research. v. 18, n. 2, p. 179-196, 2015.

PFEIFFER, P. O quadro lógico: um método para planejar e gerenciar mudanças. Revista do Serviço Público, v. 51, n. 1, p. 81-122, 2014.

PICONEZ, S. C. B. M-learning (mobile learning) novas fronteiras

PIMENTEL, N. M. A política nacional de educação a distância no Ensino Superior: elementos para um quadro de análises das relações com 0 ensino presencial. Revista Pesquisa e Debate em Educação, v. 3, n. 1, 2014.

PMBOK, Guide. A Guide to the Project Management Body of Knowledge. 5. ed. USA: PMI Institute, 2013.

POLAK, Y. N. S. A avaliação do aprendiz em EAD. LITTO, FM; FORMIGA, M. Educação a Distância: o estado da arte. São Paulo: Pearson Education do Brasil, p. 153-160, 2009.

POLIT, D. F; BECK, C. T. Fundamentos de Pesquisa em Enfermagem-: Avaliação de Evidências para a Prática da Enfermagem. Artmed Editora, 2016.

PROJECT MANAGEMENT INSTITUTE (PMI). A Guide to the Project Management Body of Knowledge (PMBOK® Guide), Project Management Institute. 2013. 
QURESHI, T.M.; WARRAICH, A.S.; HIJAZI, S.T. Significance of Project Management Performance Assessment model. In: International Journal of Project Management. Volume 27, Issue 4, May, 2009.

RAPHAEL, H.S et al. Relações entre a certificação internacional PMP de gerência de projetos e uma sala de aula. Pensamento \& Realidade, v. 9, n. 19, 2006.

RIBEIRO, L. O. M; TIMM, M. I; ZARO, M. A. Gestão de EAD: Estruturação De CEADS para Educação Profissional e Tecnológica. In: I Jornada da Produção Científica da Educação Profissional e Tecnológica da Região Sul. Florianópolis, 2007.

RILLO, M. Contexto e Prática da avaliação de iniciativas sociais no Brasil: temas atuais. São Paulo: Petrópolis, 2012.

RODRIGUES, C. A. C. Configurações das abordagens pedagógicas da educação a distância. Revista Brasileira de Aprendizagem Aberta e a Distância, v. 10, p. 71-82, 2011.

RODRIGUES, R. S; BARCIA, R. M. Modelos de educação a distância. IN: PRETI, Oresti, 2003.

RUMBLE, G. A gestão dos sistemas de ensino a distância. Ed. da UnB, 2003.

SALLES JR et al. Gerenciamento de riscos em projetos. $2^{\mathrm{a}}$. Ed. Rio de Janeiro: Editoria FGV, 2010.

SAMPAIO, M. Metodologia de gerenciamento de projetos e melhoria do desempenho. São Paulo: FGV; 2011.

SCHMIDT, T. Strategic Project Management Made Simple: Practical tools for leaders and teams. John Wiley \& Sons, 2009.

SCHÖN, D. A. Educando o Profissional Reflexivo. Porto Alegre: Artmed Editora, 2000.

SCHÖN, D. A. Educando o profissional reflexivo: um novo design para o ensino e a aprendizagem. Penso Editora, 2009.

SILVA, N. M. Análise de modelo de gestão da educação a distância em uma instituição pública de ensino superior. Centro Universitário de Anápolis UniEvangélica, 2014.

SILVA, A.C; FREIRE, F.M.P; ROCHA, H. V. Identifying Cross-Platform and CrossModality Interaction Problems in e-Learning Environments. In: ACHI 2013: The Sixth International Conference on Advances in Computer-Human Interactions, 6ª Nice, Proceedings..., 2013. 
SOUZA, C.M.S. Efetividade da gestão de projetos em instituições públicas no Brasil. 2015.113f., Monografia (Bacharelado em Administração Pública) Universidade de Brasília, Universidade Aberta do Brasil, Brasília, 2015.

SOUZA, R.A; MARTINELI, T.A.P. Considerações históricas sobre a influência de John Dewey no pensamento pedagógico brasileiro. Rev HISTEDBR On-line, Campinas, n.35, p. 160-162, set. 2009.

SPANHOL, G. K. ; DOS SANTOS, N. As Tecnologias da Informação e Comunicação e a Gestão do Conhecimento como apoio ao Gerenciamento das Comunicações em Projetos. Revista Gestão Industrial, v. 5, p. 43-58, 2009.

THOFEHRN, M. B; LEOPARDI, M. T. Construtivismo sócio-histórico de Vygostky e a enfermagem. Rev Bras Enferm, v. 59, n. 5, p. 694-98, 2006.

UNIFESP Virtual. Educação a Distância: Fundamentos e guia metodológico. Laboratório de Ensino a Distância, Departamento de Informática em Saúde, Universidade Federal de São Paulo, Escola Paulista de Medicina. 2009.

VALLE, A. B et al. Fundamentos do gerenciamento de projetos. Rio de Janeiro: FGV. 2007. 
UNIVERSIDADE DE SÄO PAULO

ESCOLA DE ENFERMAGEM

Av. Dr. Enéas de Carvalho Aguiar, 419 - CEP 05403-000

Sảo Paulo - SP - Brasil

Tel: : (11) 3061-7503/7504 - E-mail: ee@usp.br

Săo Paulo, 13 de dezembro de 2016.

III. ${ }^{\mathrm{ma}} \mathrm{Sr} .^{\natural}$

Prof." Dr. ". Cláudia Prado

Prezada Senhora,

Nos termos da documentaçăo contida no processo n. ${ }^{\circ}$ 209/2016/CPq/EEUSP, informamos que V. S. foi autorizada a realizar, nesta Unidade, a coleta de dados relativa ao projeto de pesquisa "Gestão de projeto educacional a distäncia na perspectiva do guia PMBOK",

Atenciosamente,

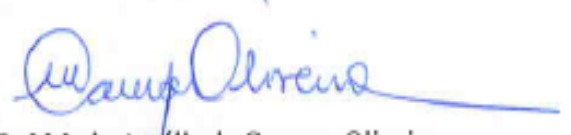

Prof.. Dr. ${ }^{2}$ Maria Amélia de Campos Oliveira

Diretora 